PNL-3416

UC-59

\title{
Evaluation of Water Source Heat Pumps for the Juneau, Alaska Area
}
J. J. Jacobsen
J. C. King
J. L. Eisenhauer
C. I. Gibson

July 1980

Prepared for the Alaska Power Administration under a Related Services Agreement with the U.S. Department of Energy under Contract DE-AC06-76RLO 1830

Pacific Northwest Laboratory Operated for the U.S. Department of Energy by Battelle Memorial Institute 
NOTICE

This report was prepared as an account of work sponsored by the United States Government. Neither the United States nor the Department of Energy, nor any of their employees, nor any of their contractors, subcontractors, or their employees, makes any warranty, express or implied, or assumes any legal liability or responsibility for the accuracy, completeness or usefulness of any information, apparatus, product or process disclosed, or represents that its use would not infringe privately owned rights.

The views, opinions and conclusions contained in this report are those of the contractor and do not necessarily represent those of the United States Government or the United States Department of Energy.

PACIFIC NORTHWEST LABORATORY operated by

BATTELLE

for the

UNITED STATES DEPARTMENT OF ENERGY

Under Contract DE-AC06-76RLO 1830

\author{
Printed in the United States of America \\ Available from \\ National Technical Information Service \\ United States Department of Commerce \\ 5285 Port Royal Road \\ Springfield, Virginia 22151 \\ $\because$ Microfiche $\$ 3.00$ \\ NTIS \\ -Pages Selling Price
}

Price: Printed Copy $\$$

001-025 \$4.00

026-050 \$4.50

051-075 $\$ 5.25$

076-100 $\quad \$ 6.00$

101-125 \$G. 50

126-150 \$7.25

151-175 $\$ 8.00$

$176-200 \quad \$ 9.00$

$201.225 \quad \$ 9.25$

226-250 $\$ 9.50$

251-275 $\quad \$ 10.75$

$276-300 \quad \$ 11.00$ 
PNL -3416

UC -59

33679000545196

EVALUATION OF WATER SOURCE HEAT

PUMPS FOR THE JUNEAU, ALASKA AREA
J. J. Jacobsen
J. C. King
J. L. Eisenhauer
C. I. Gibson

JuTy 1980

Prepared for
the Alaska Power Administration
under a Related Services Agreement
with the U.S. Department of Energy
under Contract DE-AC06-76RLO 1830

Pac ific Northwest Laboratory

Richland, Washington 99352 
-

$\checkmark$

$\cdots$

.

$-$ 


\section{CONTENTS}

FIGURES

TABLES

PREFACE AND ACKNOWLEDGMENTS . . . . . . . . . . . . . . ix

1.0 INTRODUCTION

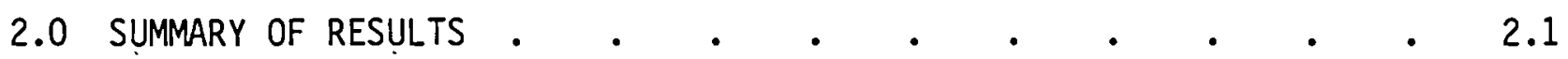

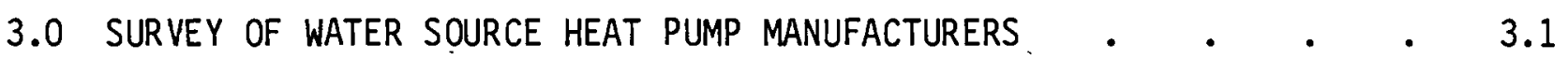

4.0 ASSESSMENT OF FOULING AND CORROSION PROBLEMS RELATED TO USE OF SEA WATER AS A HEAT SOURCE $\quad \cdot \quad \cdot \quad \cdot \quad \cdot \quad \cdot \quad \cdot \quad \cdot 4.1$

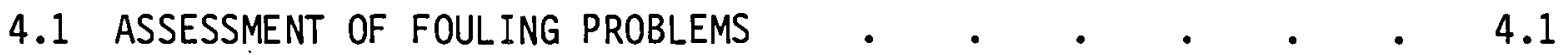

4.2 ASSESSMENT OF CORROSION PROBLEMS . . . . . . . . . 4.13

5.0 CONCEPTUAL DESIGN OF WATER SOURCE HEAT PUMP

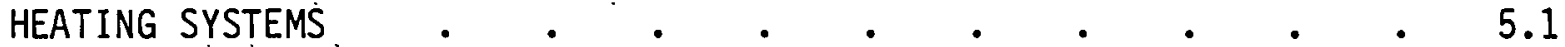

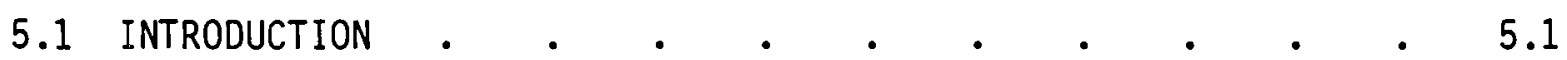

5.2 BUILDING DESIGNS AND HEAT PUMP SYSTEMS. • • • • • $\quad$ • 5.2

5.2.1 New Residential Construction in the
Mendenhall Valley. . . . . . 5.2

5.2.2 Filter Building at the Auke Bay Laboratory . • . 5.4

5.2.3 Warehouse on Juneau Waterfront ..$\quad$. $\quad .5 .5$

5.2.4 Salmon Hatchery Near Snettisham
Hydroe lectric Project . . . . . . . 5.7

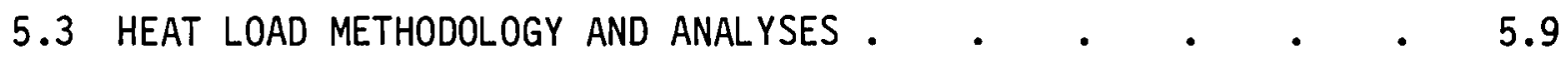

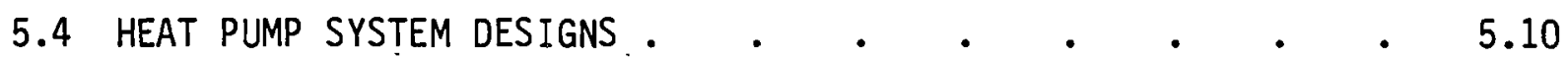

5.4.1 Mendenhall Valley Residence . . . . . . . 5.11

5.4.2 Auke Bay Filter Building . . . . . . 5.12

5.4.3 Warehouse on the Juneau Waterfront $. \quad . \quad . \quad 5.14$

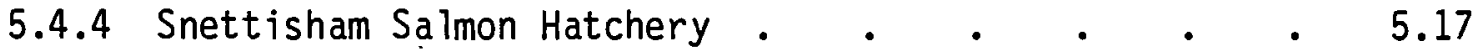




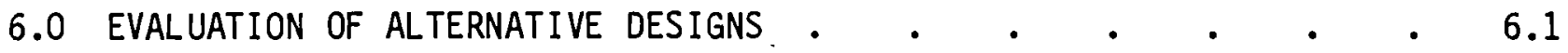

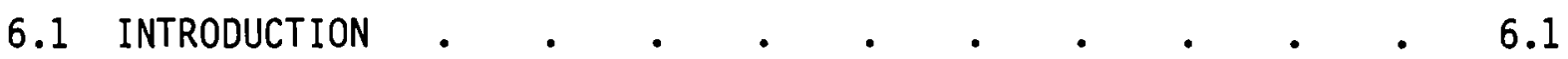

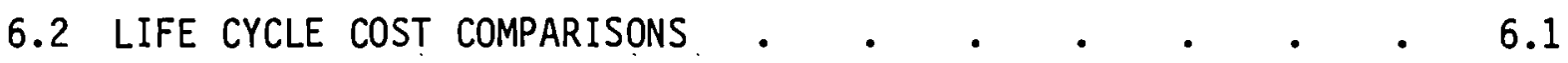

6.2.1 New Residential Construction in the
Mendenhall Valley. . . . . . . . 6.5

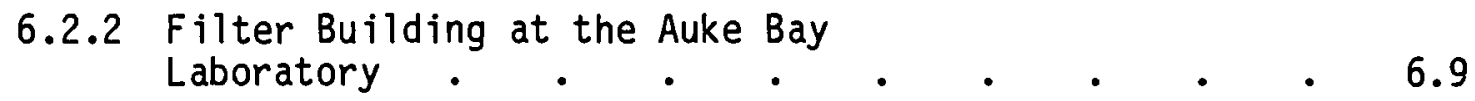

6.2.3 Warehouse on the Juneau Waterfront $. \quad . \quad$. 6.12

6.2.4 Salmon Hatchery Near Snettisham
Hydroelectric Project . . . . . . . . $\quad$. 6.15

6.3 TECHNICAL VIABILITY OF WSHPS IN THE JUNEAU AREA $\quad$ • $\quad$ • 6.17

6.3.1 General Considerations • . . . . . . 6.17

6.3.2 New Residential Construction in the
Mendenhall Valley. . . . . . . . . . 6.22

6.3.3 Filter Building at the Auke Bay Laboratory . $\quad$ - 6.22

6.3.4 Warehouse on the Juneau Waterfront $\quad . \quad$. 6.22

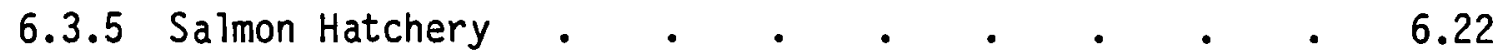

6.4 EFFECTS ON ELECTRICAL AND FOSSIL FUEL USAGE $\quad$ • $\quad$ • 6.23

7.0 RECOMMENDATIONS FOR VERIFICATION PROGRAM AND

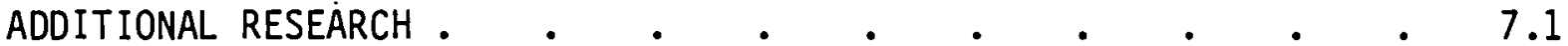

7.1 RECOMMENDATIONS FOR VERIFICATION PROGRAM $\quad$ • $\quad$ • $\quad$ • 7.1

7.2 RECOMMENDATIONS FOR ADDITIONAL RESEARCH . • • • • • 7.4

APPENDIX A - ADDITIONAL INFORMATION FROM WATER SOURCE

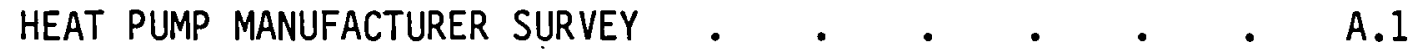

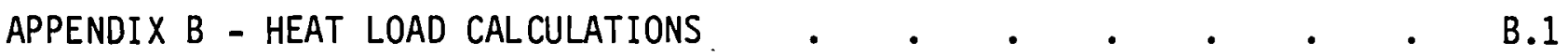

APPENDIX C - DETAILED HEATING SYSTEM DESIGN INFORMATION $\quad \bullet \quad \cdot \quad$ • c.1

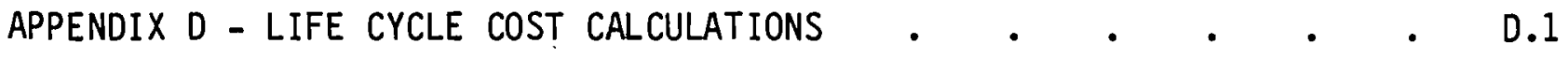




\section{FIGURES}

1.1 Actual and Forecasted Fuel 0 il Prices in the

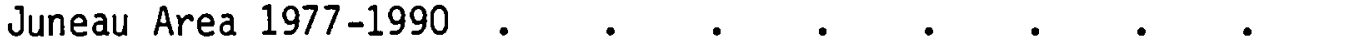

1.2 Actual and Forecasted Wholesale and Residential Electricity Price in the Juneau Area 1977-1990 . . . . 1.5

1.3 Heating Energy Cost of Electricity and Fuel $0 i 1$ Adjusted for End Use Efficiency for the Juneau Area, 1977-1990, Assuming an 8\% Rate of Inflation . . . 1.6

1.4 Comparative COPs and Heating Requirements for ASHPs and WSHPs as a Function of Exterior Temperature . . . . 1.8

1.5 Typical Ground Water Source Heat Pump Installation . . . 1.10

3.1 Price-Capacity Relationship for Water Source Heat Pumps . . . . . . . . . . . . . 3.6

4.1 Observed Water Temperature $\left({ }^{\circ} \mathrm{C}\right)$ at Selected Depths in Auke Bay, Alaska, 1960-68 . . . . . . 4.10

4.2 Observed Salinities $(\% / 00)$ at Selected Depths in Auke Bay, Alaska, 1960-68 • . . . . . . 4.11

4.3 Typical Profiles of Temperature $\left({ }^{\circ} \mathrm{C}\right)$ in Auke Bay, Alaska, for January, April, July, and October 1960-68

4.4 Typical Profiles of Salinity $(0 / 00)$ in Auke Bay, Alaska, for January, April, July, and October 1960-68

5.1 Floor Plan for Typical New Residential Construction in the Mendenhall Valley

5.2 Floor Plan for Filter Building at Auke Bay Laboratory

5.3 Floor Plan for First Floor of Warehouse on Juneau Waterfront

5.4 Floor Plan for Mezzanine of Warehouse

5.5 Floor Plan for West End of Snettisham Salmon Hatchery 
5.6 Floor Plan for East End of Snettisham

Salmon Hatchery $\quad 0.8$

6.1 Coefficient of Performance and Heating Capacity

Versus Inlet Water Temperature for Example WSHP ..$\quad$. 6.18 
1.1 Percent of Total Energy Consumption by Sector

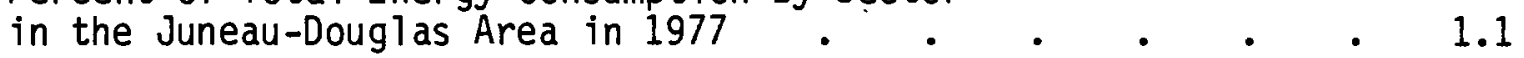

1.2 Current Residential Rates for Alaska Electrical

Light and Power Company (AEL\&P) and Glacier Highway

Electrical Association (GHEA)

2.1 Sumary of Levelized Life Cycle Costs for

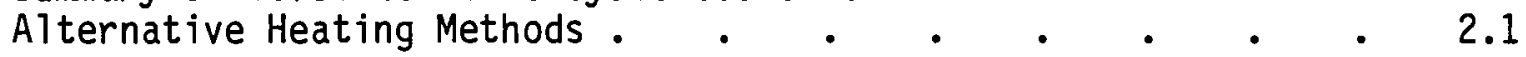

2.2 Annual $0 i 1$ and Electricity Consumption for

Alternative Heating Methods . • • • • • • . 2.2

3.1 Sumary of Water-to-Air Heat Pumps . . . . . . 3.3

3.2 Summary of Commercial Size Water-to-Air Heat Pumps . . $\quad 3.4$

4.1 Suggested Limiting Design Velocities for Copper

Alloys in Sea Water Piping Systems . • . . . . 4.15

5.1 Summary of Assumptions and Results

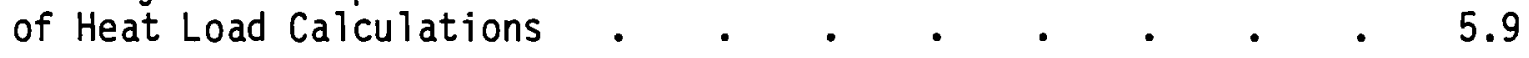

5.2 Cost Estimate, Mendenhall Valley Residence . . . . . 5.13

5.3 Cost Estimate, Auke Bay Filter Building . . . . $\quad 5.15$

5.4 Cost Estimate, Subport Warehouse . • • • • • . 5.18

5.5 Cost Estimate, Snettisham Sạlmon Hatchery . • • • • 5.21

6.1 Discount and Escalation Rates Assuming an $8 \%$
Rate of General Inflation . . . . . . . 6.2

6.2 Annual Heating Requirement for Structures

Evaluated . . . . . . . . . . . 6.3

6.3 Season System Efficiencies/COPs for Residential
Heating Systems . . . . . . . . . 6.5

6.4 O\&M Labor Requirements for Residential Heating
Systems, 1981-1990 (man-hr) . . . . . . . . . 6.6

6.5 WSHP Heating System Purchase and Installation

Costs and Equivalent Annual Investment Costs -

Mendenhall Valley Residence. 
6.6 Purchase Price and Annual Equivalent Investment Cost

for Alternative Heating Systems for Mendenhall Valley

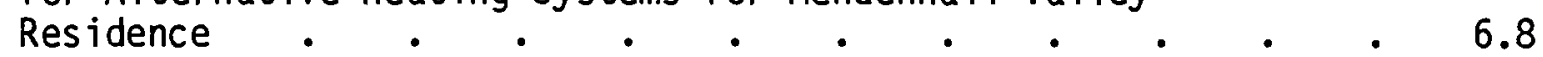

6.7 Levelized Costs for Alternative Heating Methods -

Mendenhall Valley Residence . . . . . . . . . 6.8

6.8 Heating System Purchase and Installation Costs and

Equivalent Annual Investment Costs - Filter Building . . . 6.10

6.9 Levelized Annual Costs for Alternative

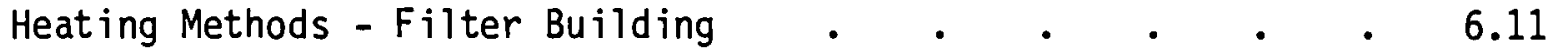

6.10 0\&M Labor Requirements for the Warehouse Heating

Systems, 1981-1990 (man-hr) . . . . . . . . 6.13

6.11 Heating System Purchase and Installation Costs

and Equivalent Annual Investment Costs - Warehouse . $\quad$ • 6.14

6.12 Levelized Annual Costs for Alternate Heating

6.13 0\&M Labor Requirements for the Salmon Hatchery
Heating Systems, 1981-1990 (man-hr)

6.14 Heating System Purchase and Installation Costs and
Equivalent Annual Investment Costs - Salmon Hatchery . . . 6.16

6.15 Levelized Annual Costs for Alternative Heating
Methods - Salmon Hatchery $. \quad . \quad . \quad$. $~ . ~$

6.16 Annual $0 i 1$ and Electricity Consumption for Alternative
Heating Methods . $\quad . \quad 6.23$ 
This report presents the findings of an analys is conducted by BattellePacific Northwest Laboratories for the Alaska Power Administration. The analys is benefitted greatly from contributions supplied by a number of people throughout both the state and the nation. In particular, we would like to acknowledge the following organizations and people:

Alaska Power Administration

Bob Cross

Floyd Summers

Alaska Electric Light and Power Company

Bill Corbus

Don Jondah 1

Jim Webb

Alaskan Refrigeration

Mike Tennison

McConaghy Construction

Jim McConaghy

Howard's Refrigeration and Heating

Dave Howard

Jack's Plumbing and Heating

Mel Dehart

Gary Dunne

Winters Electric

Steve Winters

National Marine Fisheries Service

John H. Kinney

City and Borough of Juneau

John Spietz

Vernon Akin \& Associates

Vern Ak in 
The authors hope this evaluation proves of value to the Alaska Power Administration and the residents of Juneau and southeast Alaska. We welcome comments, questions, and criticisms.

J. J. Jacobsen, Project Manager

J. C. King

J. L. Eisenhauer

C. I. Gibson 


\subsection{INTRODUCTION}

Fue 1011 is the predominant source of energy in the Juneau area. Fuel oil accounted for approximately 46 percent of the energy consumed in the Juneau area in 1977. As shown in Table 1.1, the majority of this (33 percent of the tota1) was used by the residential sector, while the remainder (12.5 percent of the total) was consumed by the commercial, industrial, and government sectors. The primary uses for fue 1 oil are space and water heating (AEA 1979, p. 5). It is estimated that over 97 percent of the residences in the Juneau area use 011 as the primary source of space and water heating. (a)

Increases in the price of fuel oil during the past year have resulted in greatly increased heating bills for residents of Juneau for both homes and businesses. During the past year, the price of fuel oil in 500 gallon quantities has increased from about $\$ 0.73$ per gallon (April 1979) to $\$ 0.93$ per galIon (Apri1 1980). During the past three years, the price has increased by over 100 percent (from about $\$ 0.46$ to about $\$ 0.93$ per gallon). (a) These prices are shown graphically in Figure 1.1 .

TABLE 1.1. Percent of Total Energy Consumption by Sector in the Juneau-Douglas Area in 1977 (Percent)

\begin{tabular}{|c|c|c|c|c|c|}
\hline Sector & Fuel 0 il & $\begin{array}{c}\text { Elec- } \\
\text { tricity } \\
\end{array}$ & $\begin{array}{l}\text { Gasoline } \\
\text { Diese 1, \& } \\
\text { Propane }\end{array}$ & $\begin{array}{c}\text { Aviation \& } \\
\text { Jet Fuel } \\
\end{array}$ & Total \\
\hline Residential & 33.4 & 4.6 & - & - & 38.0 \\
\hline $\begin{array}{l}\text { Commercial, } \\
\text { Industrial, \& } \\
\text { Government }\end{array}$ & 12.5 & 6.4 & 0.9 & - & 19.8 \\
\hline $\begin{array}{l}\text { Transportation } \\
\text { Tota } 1\end{array}$ & $\frac{-}{45.9}$ & $\frac{-}{11.1}$ & $\frac{30.7}{31.6}$ & $\frac{10.4}{10.4}$ & $\frac{41.2}{100.0}$ \\
\hline
\end{tabular}

Source: AEA 1979, p. 9.

(a) Discussions with the APA personnel, Apri1 7, 1980. 


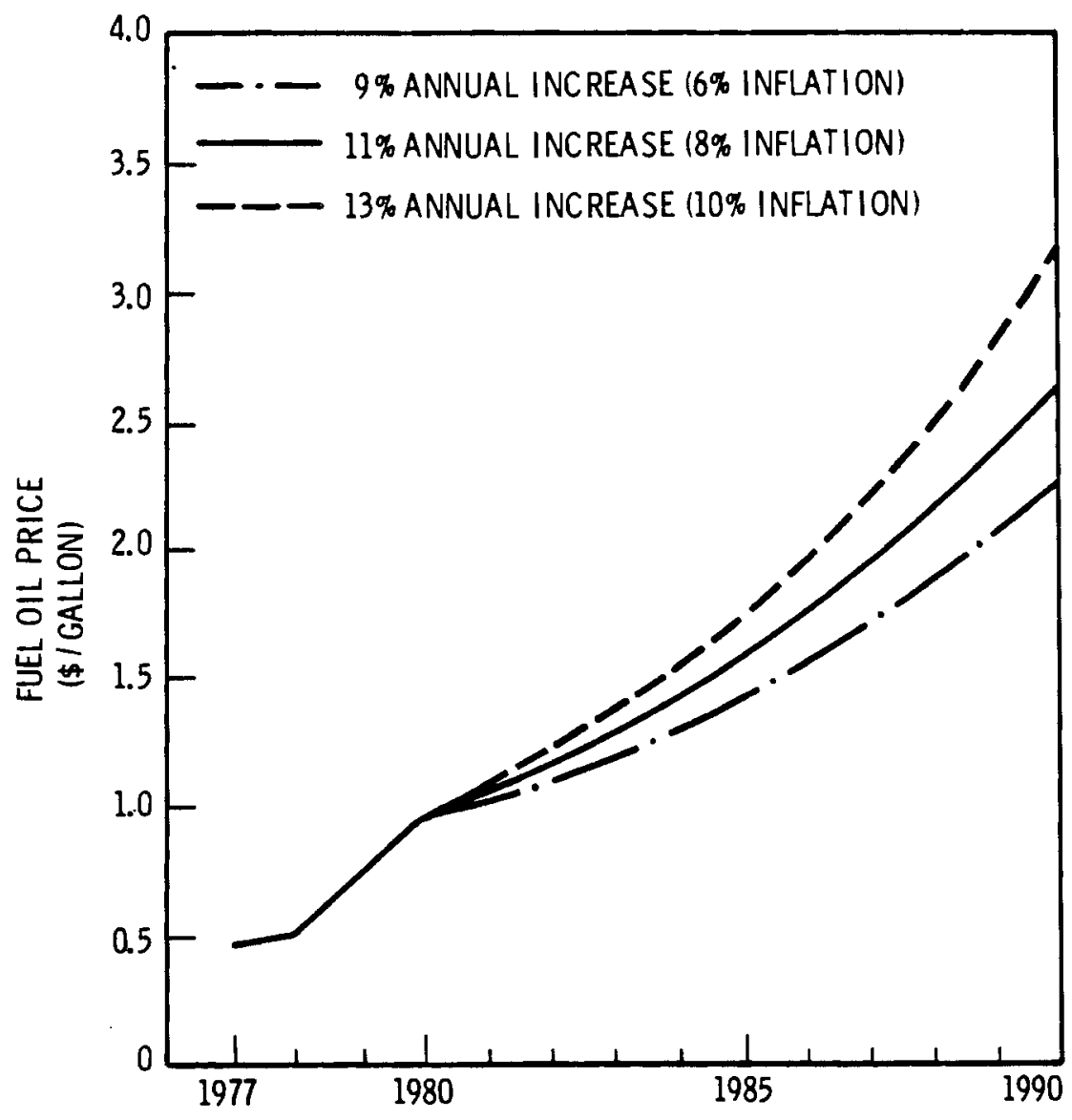

FIGURE 1.1. Actual and Forecasted Fuel 0 il Prices in the Juneau Area 1977-1990

Recent history has shown that making accurate long-term forecasts of the price of petroleum is fraught with difficulty. However, it is necessary to make assumptions regarding future prices in order to compare future energy and home heating costs. A recent study suggests that future long-term increases in petroleum product prices will be approximately 3 percent above the rate of inflation (Swift et a1. 1979, p. 7.16). While this incremental rate of increase may be conservative based upon the experience of recent years it appears to be a reasonable assumption over the 1980-1990 time period. Assuming a long-term rate of inflation of 8 percent per year would then indicate an increase of 11 percent per year in the price of fuel oil. The future price of fuel $0 i 1$, assuming an 6, 8, and 10 percent rate of inflation in the future, is shown in Figure 1.1 . 
These increases in fuel oil translate directly into similar percentage increases in the cost of space and water heating using fuel oil. Because of these relatively rapid price increases, there is widespread interest in the Juneau area in finding alternative energy sources and/or technologies that will reduce the cost of space and water heating. In addition to reducing the cost of heating, however, alternative sources of energy should be convenient to use, available to the consumer, and available in adequate supply, both now and in the future.

One alternative energy source which now appears to meet these criteria in most cases is electricity. Electricity is one of the most convenient energy sources and is available to most residential, commercial, and industrial users in the Juneau area. (a) In addition, there is presently excess hydroelectric generating capacity in the Juneau area and there appears to be adequate hydropower sites in the area to supply a large-scale conversion to electric home heating (CH2M Hill 1980, pp. 1-2).

Historically, the relative price of fuel oil versus electricity has favored the use of fuel oil for heating in the Juneau area. However, recent price increases have reversed that situation in some cases. Also, it does not appear that the price of electricity will increase as rapidly as the price of fuel oil in the future. The primary supplier of electricity in the Juneau area is the Alaska Power Administration's (APA) Snettisham hydroelectric facility. The APA presently markets power in the Juneau area at a wholesale rate of $\$ 0.0156$ per $\mathrm{kWh}$. This price is not expected to increase until 1985 . While the extent of the price increase in 1985 is not known at this time, an increase to $\$ 0.025$ per $k W h$ would seem reasonable. (b) The present residential rates for electricity for the Glacier Highway Electric Association (GHEA) and the Alaska Electric Light and Power Company (AEL\&P) are shown in Table 1.2. These prices are presented graphically in Figure 1.2 (over $180 \mathrm{kWh}$ for AEL\&P and over $750 \mathrm{kWh}$ for GHEA).
(a) In most cases, the electrical service to buildings would have to be increased and in some cases, the capacity of the electrical distribution system may have to be increased.
(b) Discussions with APA personne 1, April 7, 1980. 
TABLE 1.2. Current Residential Rates for Alaska Electrical

Light and Power Company (AEL\&P) and Glacier

Highway Electrical Association (GHEA)

\section{AEL\&P}

(Without electric water

heater or space heat)

First $200 \mathrm{kWh}--5.8 \phi$

Over $200 \mathrm{kWh}--4.4 \phi$

$+\$ 5.00 \mathrm{~min}$. charge

(With electric water heater without electric space heat)

First $180 \mathrm{kWh}--5.8 \phi$

Over $180 \mathrm{kWh}--3.6 \phi$

$+\$ 5.00 \mathrm{~min}$. charge

(With both electric water heater and space heat)

First $180 \mathrm{kWh}--5.8 \phi$

Over $180 \mathrm{kWh}--3.6 \$$

$+\$ 7.00 \mathrm{~min}$. charge
GHEA

\begin{tabular}{c} 
GHEA \\
\hline (A11 Users) \\
First 250 kWh--12.3\$ \\
Next 250 kWh-- $9.6 \$$ \\
Next 250 kWh-- $7.7 \$$ \\
Over 750 kWh-- $4.7 \$$
\end{tabular}

Source: Current rates information AEL\&P and GHEA, April 1980.

It is doubtful that the operating costs of these utilities will increase as fast as the price of fuel $0 i 1$ in the future. Present estimates indicate that Juneau area utility costs and, therefore, the utility portion of the residential price of electricity will increase at approximately one-half the rate of inflation (i.e., assuming a $8 \%$ rate of inflation electrical prices would increase at about $4 \%$ ). (a)

As shown in Figure 1.3, at present prices the cost of energy for electrical resistance heating and heating using fuel oil are very close. Assuming

(a) Battelle estimates based on conversation with William A. Corbus, manager AEL\&P, Apri 1 9, 1980. 


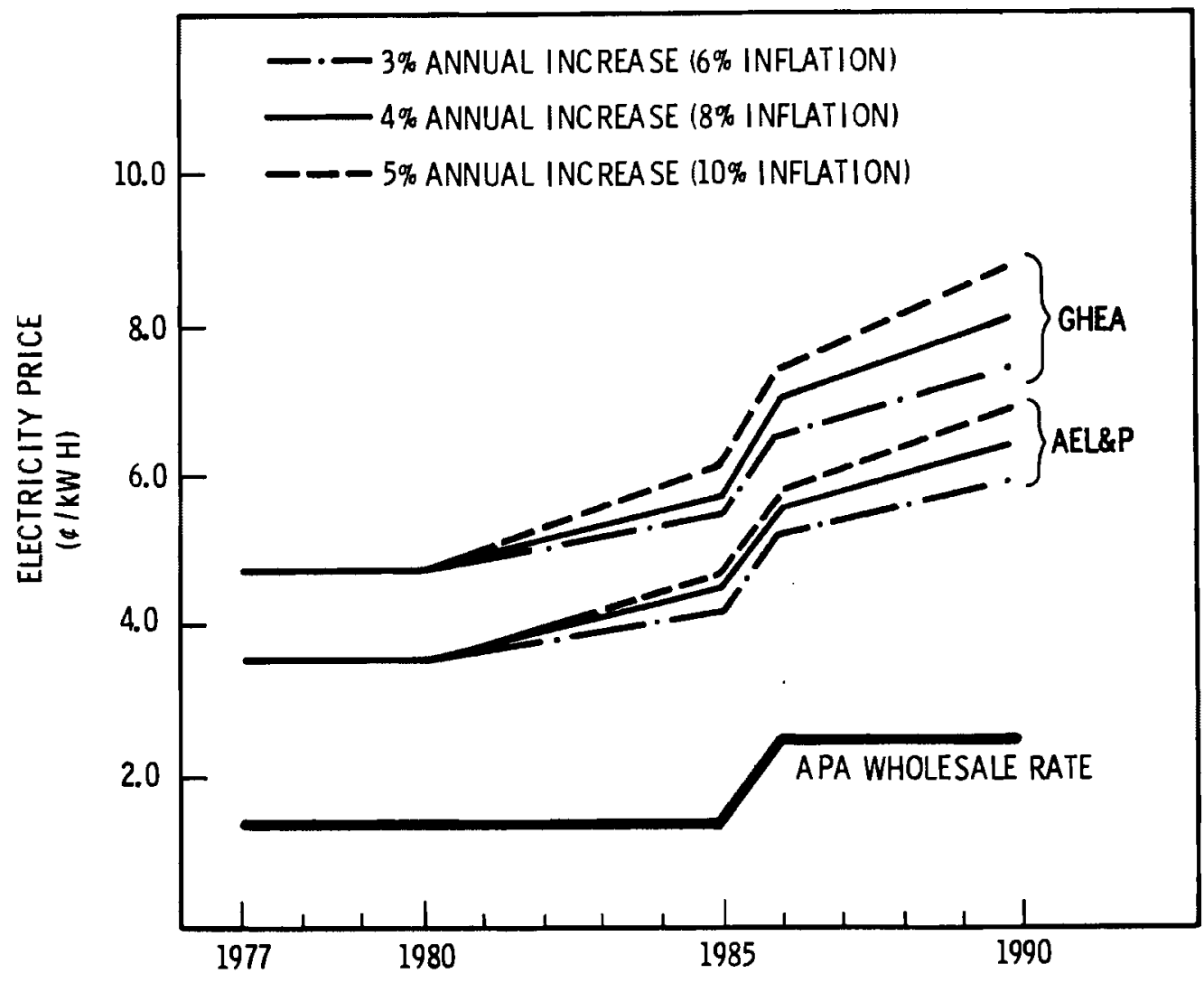

FIGURE 1.2. Actual and Forecasted Wholesale and Residential Electricity Price in the Juneau Area 1977-1990

that the heating is done with a heat pump with an annual coefficient of performance $(\mathrm{COP})^{(\mathrm{a})}$ of 2.0 , electricity has a lower energy cost than fuel oil at the present time. ${ }^{(b)}$

It is important to note that the relative costs of electricity and fuel oil for heating shown in Figure 1.3 are strongly dependent on the assumed rate of inflation. The higher the rate of inflation the more attractive electric heating becomes. At low rates of inflation energy costs for fuel oil heating will remain lower than the energy costs for heating using electrical resistance for a longer period of time.

(a) The Coefficient of Performance (COP) is a ratio calculated by dividing heating capacity in watts by power input in watts.

(b) The costs shown in Figure 1.3 include only energy. The costs of neither the heating system (oil furnace, hydronic baseboard units, electrical resistance units, etc.) nor the operating costs are included. Total heating costs are discussed and computed in chapter 6. 


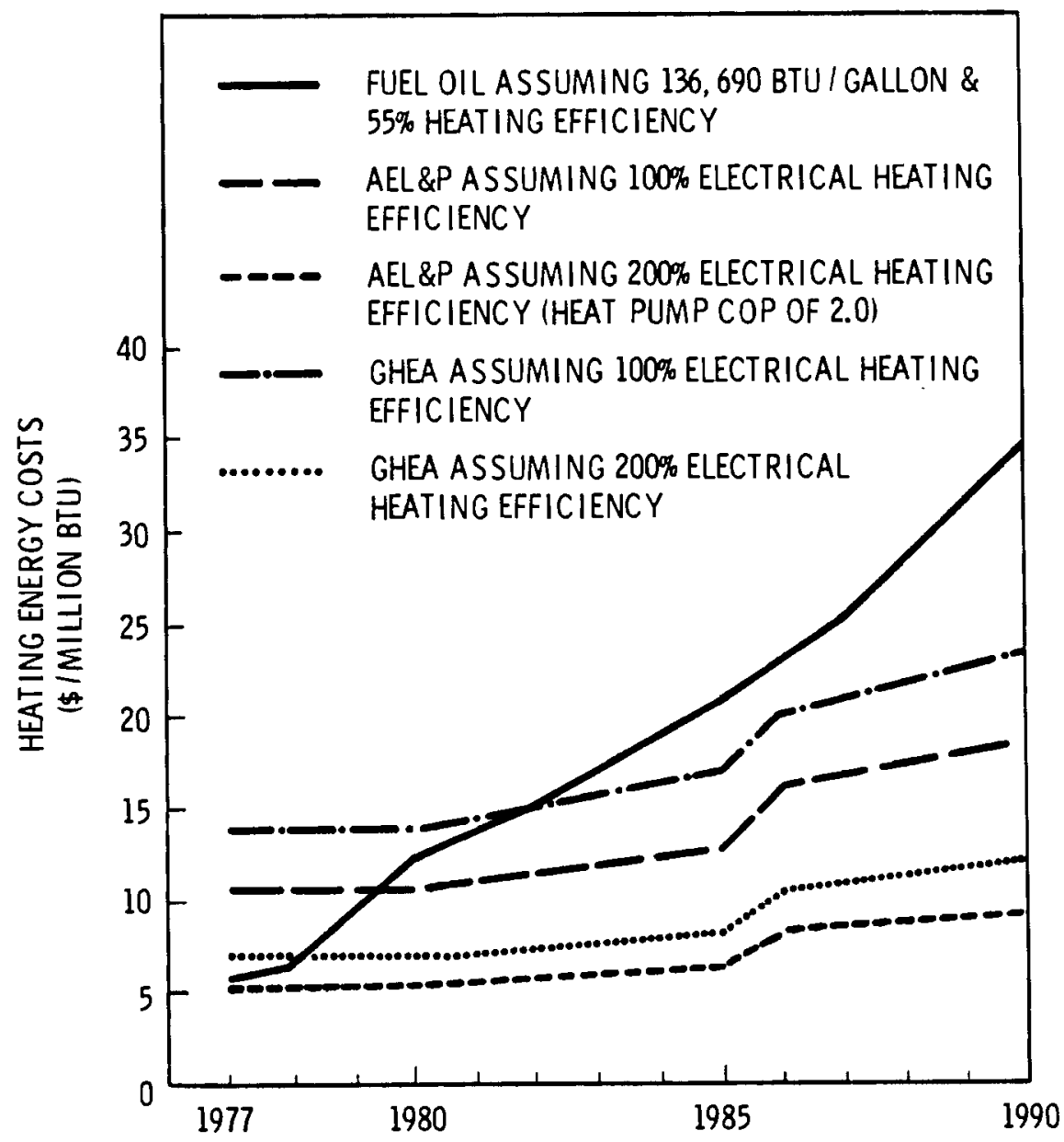

FIGURE 1.3. Heating Energy Cost of Electricity and Fuel $0 i 1$ Adjusted for End Use Efficiency for the Juneau Area, 1977-1990, Assuming an 8\% Rate of Inflation

The APA, AEL\&P, and GHEA have investigated the costs of several of the alternatives available for using electricity for space heating (AEA 1979 and CH2M Hill 1980). In these studies, the costs of heating using electrical resistance baseboard units and air source heat pumps (ASHPS) have been computed and compared to the costs of heating using fuel oil fired hydronic systems. Generally, the costs of heating using ASHPs are significantly lower and electric resistance baseboard heating marginally lower than for oil-hydronic systems depending upon the assumptions made regarding electricity and fuel oil prices (CH2M Hill 1980, p. 9). At the present time, the APA, AEL\&P, and GHEA are sponsoring an ASHP field demonstration project. 
The APA, in a continuing effort to investigate economic and efficient alternatives that will reduce fuel oil consumption by conversions to renewable hydroelectric power, has sponsored the preparation of this report evaluating the use of water source heat pumps (WSHPs) for residential, commercial, and industrial heating in the Juneau area. Heat pumps are the most efficient state-of-the-art heating system currently available.

In principle, a WSHP operates exactly like an ASHP, transferring heat from a low temperature source to a higher temperature sink. In the case of an ASHP, heat would be transferred from the outside air (the low temperature source) to the inside air (the higher temperature sink). In the case of a WSHP, the source of the heat is water. In this analysis, three possible sources of water are evaluated: ground water, sea water, and lake water.

There are several advantages of WSHPS as compared to ASHPs. One advantage stems from the fact that WSHPS operate at a constant COP, regardless of the outside air temperature. Since WSHPs use ground water or sea water, rather than the outside air, as a heat source and since ground and sea water remain at a lmost a constant temperature all year, WSHPs operate at a constant COP. The COPS for typical ASHPS and WSHPS as a function of outside air temperature are shown in Figure 1.4. As shown in Figure 1.4, the COP of ASHPs decreases as the outside air (the heat source) goes down, while the COP of WSHPs remains constant. Unfortunately, as the outside air temperature goes down, the heat load increases. As also shown in Figure 1.4, the heating load is inversely proportional to the outside air temperature. The shaded areas $A$ and $B$ represent the heating load for a typical structure. The shaded area $B$ represents the supplemental heating (typically electrical resistance) required for a ASHP installation. However, WSHP installations are typically designed to provide the full heating required at the design heating load, thus, eliminating the need for supplemental heating. The elimination of the need for electrical supplemental heating is a benefit to both the consumer and the electrical utility. The consumer benefits since less relatively expensive electrical resistance heating is required and the utility benefits because the peak demand during periods of low temperature is reduced, thus, reducing the peak generating and distribution capacity required. 


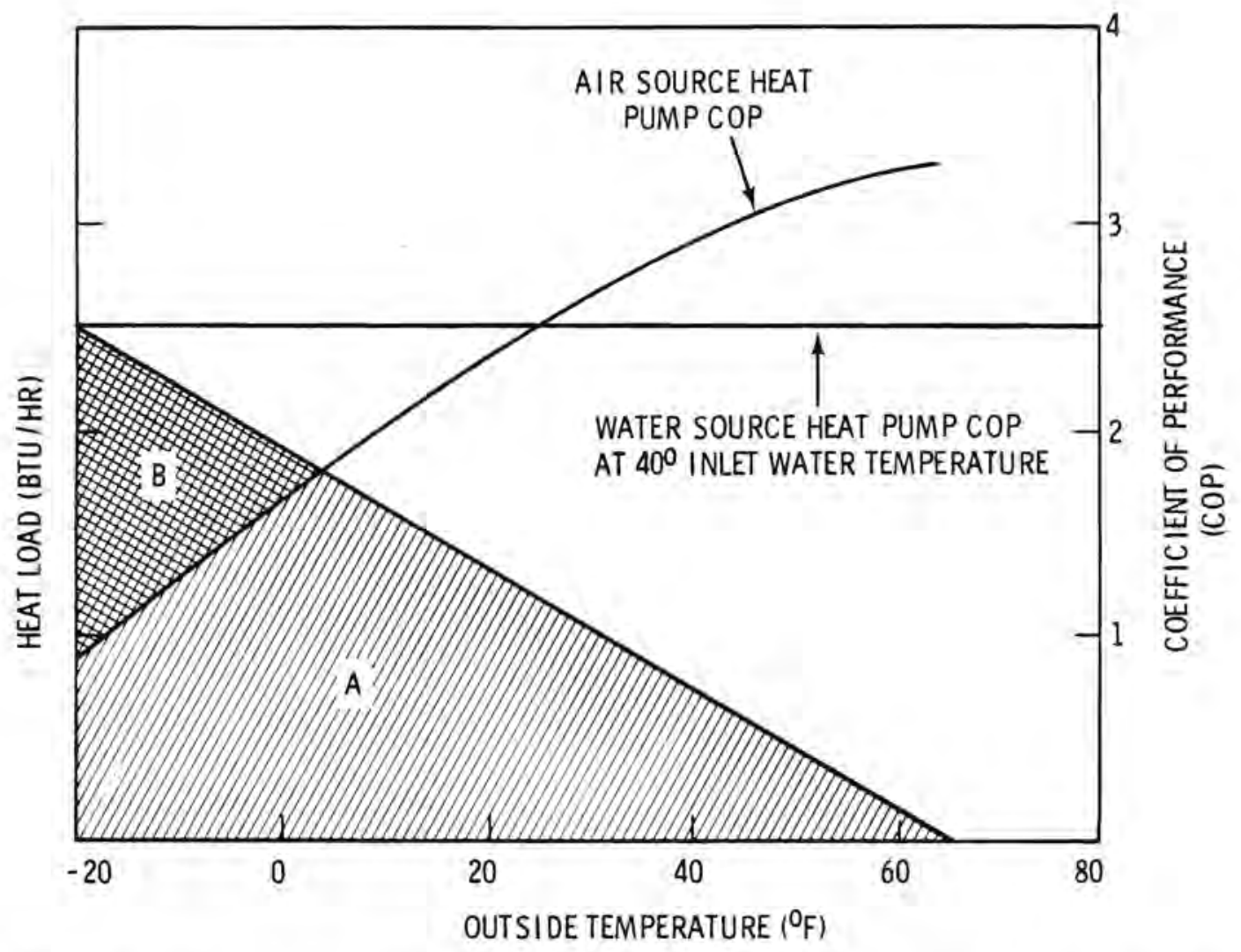

FIGURE 1.4. Comparative COPS and Heating Requirements for ASHPS and WSHPS as a Function of Exterior Temperature

\section{Source: ASHP COP - (AEA 1979, p. 99) \\ WSHP COP - Various manufacturer data sheets and contacts. Includes blower and pump allowance.}

Another advantage of WSHPS is the fact that WSHPs are typically selfcontained. The water supply is typically piped to and from the unit in relatively small diameter ( 1 to 1.5 -inch diameter) PVC pipe. There is no external heat exchanger with the associated refrigerant piping and electrical wiring, as is required with an ASHP. Typical WSHPs are about the size and shape of a small refrigerator (28 inches wide $\times 28$ inches deep $\times 48$ inches high).

Of course, there are also disadvantages of WSHPs relative to ASHPs. Perhaps the most significant disadvantage is the need to have a water supply and disposal system. In the case of a ground water system, a we11, a water pump, water piping, and electrical power is required. Disposal of the effluent water 
can also be a problem, especially during freezing weather. The most common method of disposing of the water is to use a separate return well. For a sea water system, there is still the need for a water supply pump and piping, as well as disposal piping. In addition, the problem of marine fouling in the pipes and heat exchanger must be dealt with in sea water systems. Salt water corrosion, while a problem, can typically be alleviated through the proper selection of materials.

Another problem with WSHPs is that at the present time, they are not as common as ASHPS. This means that there are fewer distributors who handle WSHPS and those who do, have less experience regarding installation and maintenance practices. While this situation is changing, nevertheless, it is a factor to include in the decision as to whether to install a WSHP especially in the Juneau area.

Figure 1.5 shows a sketch of a typical ground WSHP installation using separate supply and disposal wells. As shown, the heat pump is a single cabinet located inside the building. The cabinet contains a heat exchanger, a compressor, an air blower and air heating coils, and the necessary piping, wiring, and controls. Water is supplied to the heat pump from a well and is returned to another disposal we11. Of course, if sea water is used there would be no need for either a supply or disposal wel1. The supply pump would be located either near or in the sea water. The water would be returned to the sea for disposal. One option, which is not evaluated in this report, involves locating the refrigerant heat exchanger directly in a body of water such as a lake or the sea. This option eliminates the need for the water supply system but requires longer refrigerant piping runs. In some cases where the building to be heated is located close to the body of water this system may be relatively attractive.

The purposes of this project and report are to evaluate the technical and economic viability of WSHPs for use in the Juneau area, and to identify potential demonstration projects to verify their viability. This report is divided into six additional chapters.

Chapter 2 presents a brief summary of the results of the project. 


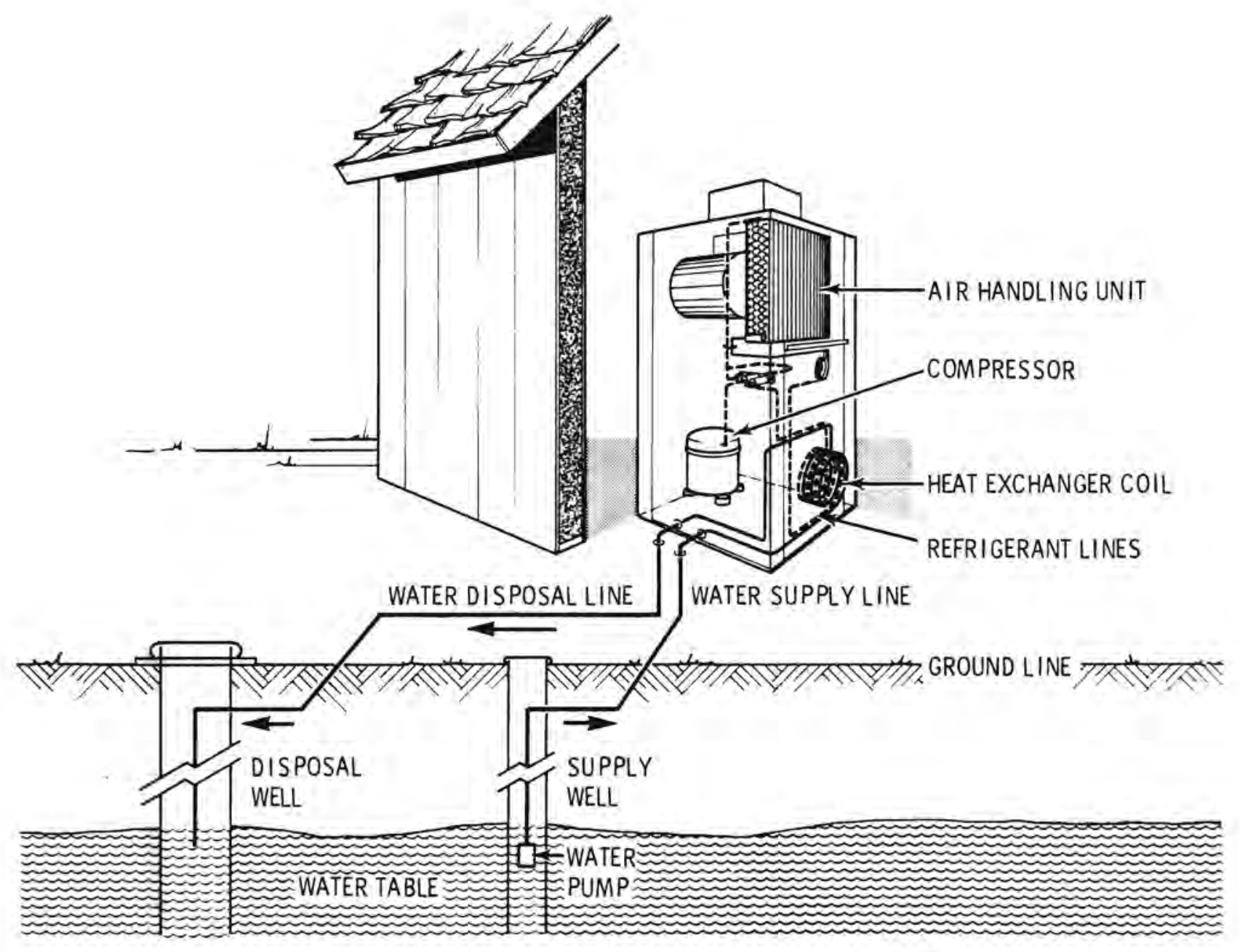

FIGURE 1.5. Typical Ground Water Source Heat Pump Installation

The first task undertaken on the project was to contact manufacturers and distributors to identify the specifications, price, and availability of presently available WSHPS. The results of this survey are contained in Chapter 3. Additional information regarding manufacturers and distributors of WSHP equipment and WSHPS is contained in Appendix A.

Because of the proximity of Juneau and other southeast Alaska communities to sea water, a brief evaluation was made of the possible use of sea water as a heat source. This evaluation was limited in scope to literature research and conversations with knowledgeable people in the field of sea applications and use. The results of this analysis are contained in Chapter 4. 
To provide a basis for the economic evaluation of WSHPs relative to other types of heating presently used in the Juneau area, four building types and WSHP applications were selected for detailed analysis. A WSHP-based heating system was selected for each of the cases. These buildings and applications were selected to be representative of the current Juneau residential and commercial building stock. Once the four cases were chosen, the heat load for each was calculated and a preliminary heating system design developed. The results of the building selection, the heat load calculations, and the heat system design activities, are presented in Chapter 5 . Additional details on the heat load calculations are contained in Appendix $B$ and more detailed heating system design information is contained in Appendix $C$.

Chapter 6 presents the results of the evaluations of the four case studies. These evaluations are based upon three major considerations: 1) life cycle costs, 2) technical viability, and 3) effect on fossil and electrical energy use. The object of the technical evaluation is to identify those systems which appear to be most promising from the standpoint of installation, operation, and maintenance. Because of the high cost of fuel oil and the availability of electric power in the Juneau area, the impact of WSHPs on the consumption of these energy sources is analyzed. The life cycle costs for the WSHP-based heating system are compared with the costs of alternative heating systems. The details of the cost analyses are the contents of Appendix D.

The final chapter of this report presents recommendations for a program to verify the technical and economic viability of WSHPS in the Juneau area.

In this report, there is no analys is of the legal and environmental aspects of WSHP use. In some areas, there may be local restrictions on ground water extraction and disposal, although there do not appear to be any statewide restrictions. There are state and federal restrictions on the use of sea water. Anyone interested in installing either a ground water source heat pump or a sea water source heat pump should investigate the restrictions and/or permits required before proceeding with a detailed design or installation. 


\section{REFERENCES - CHAPTER 1.0}

Applied Economics Associates, Inc. March 1979. The Role of Electric Power in the Southeast Alaska Energy Economy. Prepared for the Alaska Power Administration, Juneau, Alaska.

CH2M Hill. February 1980. A Comparison of Home Heating Costs: Electricity Versus 0 il. Prepared for the Glacier Highway Electric Association, Auke Bay, Alaska.

Swift, W. H. et al. March 1978. Alaskan Electric Power - An Analysis of Future Requirements and Supply Alternatives for the Railbelt Region. Prepared by Pacific Northwest Laboratory, for the Alaska Division of Energy and Power Development and the Alaska Power Authority. 


\subsection{SUMMARY OF RESULTS}

- Based upon the cost evaluations described in this report, which are summarized in Table 2.1, WSHP heating systems offer life cycle heating costs that are generally comparable or slightly higher than other types of heating available in the Juneau area. For a typical new residence in the Mendenhall Valley a WSHP heating system offers life cycle heating costs that are comparable to electrical resistance heating. An ASHP heating system provides lower heating costs than either electrical resistance or WSHP heating while an oil-hydronic system has the highest costs of all the systems evaluated for the residence. For the Filter Building (a frame building located at the National Marine Fisheries Services Auke Bay Laboratory) the costs of heating the building using a WSHP system are roughly comparable to the costs of heating the building using a forced air oil furnace. For a warehouse/shop building located on the Juneau waterfront the costs of heating the building using a WSHP system are slightly higher than the costs of heating the building using an oil-hydronic heating system. In the case of a salmon hatchery located near Snettisham electrical resistance heating is about $8 \%$ lower in cost than the WSHP system.

TABLE 2.1. Summary of Levelized Life Cycle Costs for Alternative Heating Methods (\$)

\begin{tabular}{lccccc} 
Heating Method & $\begin{array}{c}\text { Mendenhal1 } \\
\text { Valley } \\
\text { Residence }\end{array}$ & $\begin{array}{c}\text { Auke Bay } \\
\text { Building } \\
\text { Filter }\end{array}$ & $\begin{array}{c}\text { Juneau } \\
\text { Water Front } \\
\text { Warehouse }\end{array}$ & $\begin{array}{c}\text { Snettisham } \\
\text { Salmon } \\
\text { Hatchery }\end{array}$ \\
\cline { 1 - 1 } $\begin{array}{l}\text { Direct Electrical } \\
\text { Resistance }\end{array}$ & 2921 & -- & -- & 9640 \\
$\begin{array}{l}\text { Fluid Filled Electrical } \\
\quad \text { Resistance }\end{array}$ & 2999 & -- & -- & -- \\
Oil Furnace & 4495 & 3208 & 11,155 & -- \\
Air Source Heat Pump & 2283 & -- & -- & -- \\
Water Source Heat Pump & 3092 & 3254 & 13,749 & 10,516
\end{tabular}


- Water source heat pumps using either fresh water or sea water are technically viable in the Juneau area. Both sea water and fresh water of acceptable temperature, quality, and quantity are available. It must be kept in mind, however, that in some cases an acceptable water source will not be available. If so, the water supply must be made acceptable or an alternative method of heating selected. The prospective water source must be carefully evaluated on a case-by-case basis early in the planning process. While there are fouling and corrosion problems associated with the use of sea water it appears that these problems can be overcome through proper design and materials selection.

- Proper installation and maintenance is of paramount importance for WSHPs. Experience suggests that most of the failures and service calls for WSHP installations are related to improperly designed or installed water supply systems or air handling systems. In general, a WSHP itself should be as or more reliable than an ASHP. All WSHP designs and installation should be made by qualified people with a knowledge of WSHP applications.

- Annual oil and electricity consumption for the alternative heating methods evaluated in this report are presented in Table 2.2. Use of WSHPs for heating in the Juneau area could reduce the use of fossil fuels while increasing the use of electricity. However, the increase in electricity

TABLE 2.2. Annual 0 il and Electricity Consumption for Alternative Heating Methods

Electrical

Resistance

(Electricity)

(kWh)

Residence

53,875

0 il Heat

(Fuel 0il)

(gal)

2412

1645

4853

Building

Warehouse

Salmon

Hatchery
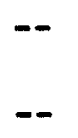

205,033
ASHP

(Electricity)

(kWh)

28,114

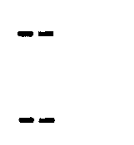

15,195

60,028

82,013 
use would be relatively low compared to electrical resistance heating since WSHPS offer seasonal COPs from 2.25 to 2.5. The energy consumption estimates for the residence are similar to estimates for Juneau area residences contained in other recent studies (AEA 1979, p. 99 and CH2M Hill 1980, Appendix Table 8). However, these estimates are higher than the average "all electric" residential consumption of 24,216 kWh derived from 1977 electrical consumption data for the Juneau area (AEA 1979, p. 14). There are several possible reasons for this difference. They include differences between the design interior temperature $\left(70^{\circ} \mathrm{F}\right)$ and the temperatures maintained in actual practice, possible use of supplemental heating in existing residences, differences in the size and location of the residences, and differences in insulation. These reasons are discussed in more detail in Section 6.4 .

- During the survey of heat pump manufacturers and data collection efforts, 19 manufacturers of WSHPS were contacted. Twelve of them have Northwest distributors in the Seattle, Portland, or Spokane areas. All made residential sized units (to $100,000 \mathrm{Btu} / \mathrm{hr}$ ) and 8 made commercial sized units (over 100,000 Btu/hr). Several manufacturers offer standard units which operate on water in the 38 to $45^{\circ} \mathrm{F}$ temperature range that is common in the Juneau area.

- Because of the relatively low water temperatures, possible fouling and corrosion problems associated with the use of sea water, and uncertainties about the availability of proper design and maintenance in Juneau, a field demonstration program to verify the results of this report should be conducted before a final recommendation is made as to the viability of WSHPS in the Juneau area. 


\section{REFERENCES - CHAPTER 2.0}

Applied Economics Associates, Inc. March 1979. The Role of Electric Power in the Southeast Alaska Energy Economy. Prepared for the Alaska Power Administration, Juneau, ATaska.

CH2M Hi1l. February 1980. A Comparison of Home Heating Costs: Electricity Versus 0il. Prepared for the Glacier Highway Electric Association, Auke Bay, Alaska. 


\subsection{SURVEY OF WATER SOURCE HEAT PUMP MANUFACTURERS.}

An intricate portion of the evaluation of water source heat pump potential for southeast Alaska was an investigation of existing manufacturers of waterto-air heat pumps. While air-to-air heat pumps are widely manufactured and used in many parts of the U.S., water-to-air and water-to-water heat pumps are less abundant.

Three principle sources were used to obtain a comprehensive list of heat pump manufacturers: Directory of Certified Applied Air Conditioning Products (ARI 1979), Heat Pump Manufacturers List from the National Water Well Association (NWWA 1980), and the Portland and Seattle Yellow Pages. After a master list was compiled the manufacturers and distributors were contacted by phone. A complete listing of water source heat pump manufacturers and distributors with their addresses is included in Appendix $A$ of this report.

Of the 45 heat pump manufacturers and distributors contacted, approximately half made water source heat pumps. These manufacturers fell into two general categories: large heating and air conditioning companies that carried a line of water source heat pumps and small companies that specialized in heat pumps or solar/heat pump systems.

Most of the manufacturers that produce water source heat pumps produce only water-to-air or air-to-air systems. Three companies produce water-towater systems, six companies produce solar assisted systems, one company uses a closed-10op circulating refrigerant system, and one company uses heatmats to collect heat from water or ground sources.

Existing water-to-water heat pumps are limited in their application for residential space heating because of the relatively low heated water temperatures they produce. In most cases the heated water is in the 120 to $140^{\circ} \mathrm{F}$ range. Water at these temperatures is not suitable for use in conventional fan coil or baseboard heating units. Such units require water temperatures in the 170 to $190^{\circ} \mathrm{F}$ range. Existing water-to-water units are suitable for radiant heating applications such as systems where water pipes are embedded in the floor. 
Most water-to-air heat pump manufacturers produce several models for various heating capacity requirements. All manufacturers in the survey produced residential size units $\left(10,000-100,000 \mathrm{BtuH}^{(\mathrm{a})}\right)$ and eight produced commercial size units (over 100,000 BtuH). A summary of water-to-air heat pump manufacturers, heating capacity, and northwest distributors is presented in Table 3.1.

It is important to note that manufacturers use different methods to rate heating capacity. Heating capacity is a function of water flow rate, indoor air temperature, and entering water temperature. Therefore, heating capacity ratings from different manufacturers may not be comparable unless these variables are specified.

Twelve of the nineteen brands of water-to-air heat pumps have Northwest distributors in the Seattle, Portland, or Spokane areas. Brands without Northwest distributors tended to be the newer companies. Most of the Northwest distributors believed they could supply their brand of heat pump with little or no delay. Some, however, expressed concern over proper installation and serviceability of their units in southeastern Alaska.

Eight companies produce commercial size water-to-air units; five of these companies have Northwest distributors. A summary of commercial size water-toair heat pumps is listed in Table 3.2 .

In most cases the commercial sized units are not suitable for low inlet water temperature applications. These units are typically designed for large commercial applications utilizing a water boiler and including waste heat recovery systems. They are designed for inlet water temperatures in the range of 60 to $90^{\circ} \mathrm{F}$. At the present time it appears that the best way to heat larger buildings using low temperature water is to use multiple residential sized units designed specifically for low water temperature applications.

Prices of heat pumps varied significantly depending on system options. Some prices reflect the basic heat pump unit while others include control systems. Prices also varied depending on the type of electrical service (one or

(a) Two abbreviations for British Thermal Units per hour are used in this report, BtuH and Btu/hr. 


\section{TABLE 3.1. Summary of Water-to-Air Heat Pumps}

\begin{tabular}{|c|c|c|c|}
\hline Company & Brand & Models $(a)(b)$ & Northwest Distributor \\
\hline American Air Filter & EnerCon & $\begin{array}{l}9 \text { Models } \\
10,000-62,000 \mathrm{BtuH}\end{array}$ & -- \\
\hline Carrier & Carrier & $\begin{array}{l}6 \text { Models } \\
14,000-42,000 \text { BtuH }\end{array}$ & Airefco Inc. \\
\hline Command-Aire & Command-Aire & $\begin{array}{l}16 \text { Models } \\
12,000-350,000 \text { BtuH }\end{array}$ & Brod and McClung-Pace $\mathrm{Co}$. \\
\hline Conservation Technology & Convectionaire & $\begin{array}{l}5 \text { Mode ls } \\
13,000-41,000 \text { B tuH }\end{array}$ & -- \\
\hline Florida Heat Pump & Energy Miser & $\begin{array}{l}14 \text { Models } \\
13,000-240,000 \mathrm{BtuH}\end{array}$ & Peerless Pacific \\
\hline Friedrich & $\begin{array}{l}\text { Friedrich- } \\
\text { Climate Master }\end{array}$ & $\begin{array}{c}4 \text { Models } \\
41,000-61,000 \text { BtuH }\end{array}$ & Airtec \\
\hline Heat Controller & $\begin{array}{l}\text { Century/Comfort } \\
\text { Aire }\end{array}$ & $\begin{array}{l}17 \text { Models } \\
25,000-410,000 \text { BtuH }\end{array}$ & Hardesty \\
\hline Heat Exchanger & KoldWave & $\begin{array}{l}12 \text { Models } \\
11,000-250,000 \mathrm{BtuH}\end{array}$ & Pameco-Aire \\
\hline $\begin{array}{l}\text { International Energy } \\
\text { Conservation Systems Inc. }\end{array}$ & TempMaster & $\begin{array}{l}16 \text { Models } \\
15,000-400,000 \text { BtuH }\end{array}$ & -- \\
\hline Manmoth & Hydrobank & $\begin{array}{l}31 \text { Models } \\
10,000-930,000 \text { BtuH }\end{array}$ & Enviro Air Systems \\
\hline Northrup, Inc. & Northrup & $\begin{array}{l}9 \text { Models } \\
10,000-71,000 \text { BtuH }\end{array}$ & $\begin{array}{l}\text { Hal Teasley and } \\
\text { Associates, Inc. }\end{array}$ \\
\hline Phoenix & Enviro-Temp & $\begin{array}{l}5 \text { Models } \\
33,000-95,000 \text { BtuH }\end{array}$ & -- \\
\hline Singer & Singer & $\begin{array}{l}6 \text { Mode ls } \\
18,000-58,000 \text { BtuH }\end{array}$ & $\begin{array}{l}\text { Hal Teasley and } \\
\text { Associates, Inc. }\end{array}$ \\
\hline $\begin{array}{l}\text { "Solar Oriented" } \\
\text { Environmental Systems Inc. }\end{array}$ & SOESI/SERCO & $\begin{array}{l}11 \text { Models } \\
18,000-244,000 \text { BtuH }\end{array}$ & -- \\
\hline $\begin{array}{l}\text { Thermal Energy } \\
\text { Transfer Company }\end{array}$ & TETCO & $\begin{array}{l}2 \text { Models } \\
40,000-52,000 \text { BtuH }\end{array}$ & Pitcher Pump \\
\hline $\begin{array}{l}\text { Vanguard Energy } \\
\text { Systems }\end{array}$ & Vanguard & $\begin{array}{l}5 \text { Models } \\
27,000-72,000 \text { BtuH }\end{array}$ & -- \\
\hline Wescorp & Sol argy & $\begin{array}{l}10 \text { Models } \\
15,000-104,000 \mathrm{BtuH}\end{array}$ & Brod and McClung-P ace Co. \\
\hline Whaten & Whalen & $\begin{array}{l}4 \text { Models } \\
26,000-72,000 \text { BtuH }\end{array}$ & R. D. Morse Company \\
\hline York & York & $\begin{array}{l}3 \text { Mode is } \\
23,000-45,000 \text { BtuH }\end{array}$ & Day-York \\
\hline
\end{tabular}

(a) Heating capacity is a function of water flow rate (GPM), indoor air temperature (OF), air flow rate (CFM), and entering water temperature ( ${ }^{\circ} F$ ). Many manufacturers use different values for these factors and their heating capacity may not be comparable with those of other manufacturers. In many cases the manufacturer supplied a single value of heating capacity. When several values were given, the one closest to the ARI standards was chosen.

(b) Heating capacities are rounded to the nearest 1000 BtuH. 
TABLE 3.2. Summary of Commercial Size Water-to-Air Heat Pumps

\begin{tabular}{|c|c|c|c|}
\hline Company & Brand & Models $(a)(b)$ & Northwest Distributor \\
\hline Command-A ire & Command-Aire & $\begin{array}{c}7 \text { Mode 1s } \\
101,000-338,000 \text { BtuH }\end{array}$ & Brod and McClung-Pace Co. \\
\hline Florida Heat Pump & Energy Miser & $\begin{array}{c}4 \text { Mode ls } \\
107,000-262,000 \text { BtuH }\end{array}$ & Peerless Pacific \\
\hline Heat Controller & Comfort-Aire & $\begin{array}{l}6 \text { Models } \\
105,000-410,000 \mathrm{BtuH}\end{array}$ & Hardesty \\
\hline Heat Exchangers Inc. & KoldWave & $\begin{array}{l}4 \text { Models } \\
108,000-249,000 \mathrm{BtuH}\end{array}$ & Pameco-A ire \\
\hline $\begin{array}{l}\text { International Energy } \\
\text { Conservation Systems Inc. }\end{array}$ & TempMaster & $\begin{array}{c}7 \text { Mode ls } \\
104,000-400,000 \mathrm{BtuH}\end{array}$ & -- \\
\hline Mammoth & Hydrobank & $\begin{array}{l}23 \text { Models } \\
115,000-930,000 \text { BtuH }\end{array}$ & Enviro Air Systems \\
\hline $\begin{array}{l}\text { "Solar Oriented" } \\
\text { Environmental Systems Inc. }\end{array}$ & SOESI/SERCO & $\begin{array}{l}5 \text { Models } \\
106,000-244,000 \text { BtuH }\end{array}$ & -- \\
\hline Wescorp & Solargy & $\begin{array}{c}1 \text { Mode } 1 \\
104,000 \text { BtuH }\end{array}$ & Brod and McClung-Pace Co. \\
\hline
\end{tabular}

(a) Heating capacity is a function of water flow rate (GPM), indoor air temperature ( $\left.{ }^{\circ} \mathrm{F}\right)$, air flow rate (CFM), and entering water temperature ( ${ }^{\circ}$ ). Many manufacturers use different values for these factors and their heating capacity may not be comparable with those of other manufacturers. In many cases the manufacturer supplied a single value of heating capacity. When several values were given, the one closest to the ARI standards was chosen.

(b) Heating capacities are rounded to the nearest $1000 \mathrm{BtuH}$. 
three phase) and the physical characteristics of the unit (horizontal or vertical). A price-capacity curve is shown in Figure 3.1. A complete listing of prices by capacity and brand is included in Appendix $A$.

Eight brands (Century, KoldWave, Vanguard, TETCO, Solargy, Carrier, Friedrich, and Enviro-Temp) reported that they operate in the $40^{\circ}-45^{\circ} \mathrm{F}$ entering water temperature range. Other brands may also operate in this range by altering their water flow rate but did not specifically state so in their brochures. Several distributors indicated that their heat pumps can accept low temperature water if appropriate adjustments are made to the system. This may include adjusting water flow rates or adding system options to heat pump packages.

In summary, it appears that there are several brands of water-to-air heat pumps that are applicable to the climate and structure size encountered in southeast Alaska. Most manufacturers supply a variety of sizes and have distributors in the Pacific Northwest. 


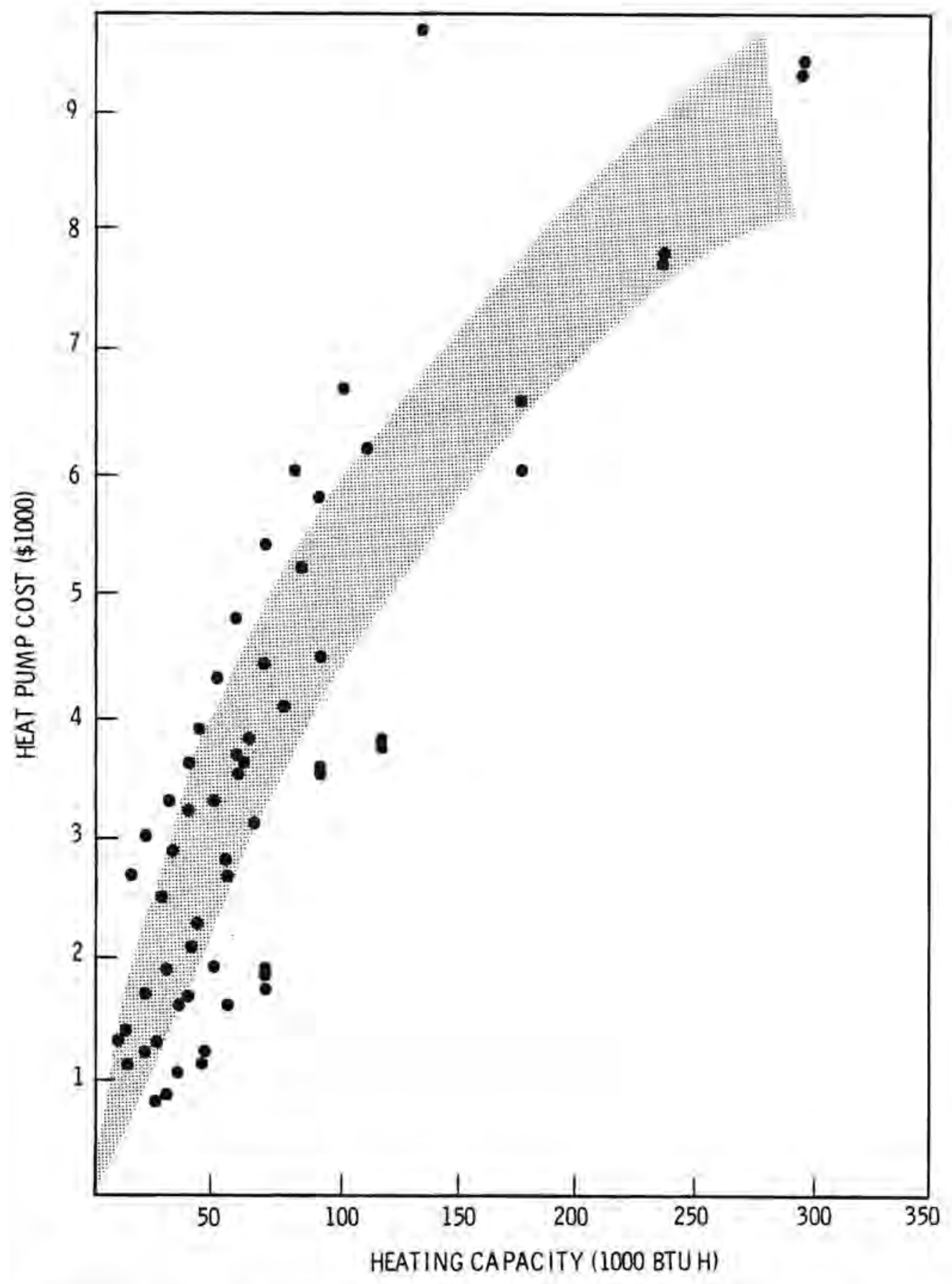

FIGURE 3.1. Price-Capacity Relationship for Water Source Heat Pumps (Spring 1980 Price Leve1s) 
Air-Conditioning and Refrigeration Institute. 1979. Directory of Certified App lied Air-Conditioning Products, December 1, 1979 - May 31, 1980. Arlington, Virginia.

Christian, J. E. 1977. Unitary Water-to-Air Heat Pumps. ANL/CES/TE 77-9. Prepared for Argonne National Laboratory by Oak Ridge National Laboratory, Oak Ridge, Tennessee.

Hildebrandt, A. F. and F. R. Elliott. 1979. Ground Water Heat Pump HVAC Demonstration Project Phase 1 - Design Development. EDF-01F. Prepared for the Texas Energy Advisory CounciT, Houston, Texas.

National Water Well Association. 1980. "Heat Pump Manufacturers." Obtained at The National Ground Water Geothermal Heat Pump Conference and Exposition, February 11-12, 1980, Ohio State University, Columbus, Ohio. 



\subsection{ASSESSMENT OF FOULING AND CORROSION PROBLEMS.}

RELATED TO USE OF SEA WATER AS A HEAT SOURCE

Fouling and corrosion are the two most serious problems related to the use of sea water as a heat source in WSHPS. Each of these problems and methods of overcoming them are discussed in this chapter. The annual temperatures and temperature variation of sea water in the Juneau area is also briefly discussed.

\subsection{ASSESSMENT OF FOULING PROBLEMS}

One of the problems in using sea water as a heat source in a heat pump system is the fouling (growth of marine organisms) that can occur on any surface exposed to marine water. Within marine water are a large number of larval forms that are able to pass through most screens and/or pumps and eventually settle out and grow into large adult forms which can clog a circulating water system and/or create an effective barrier to good heat exchange across surfaces. This problem is common to heat exchanger systems that use marine waters. The problem has been solved in large heat exchange systems, such as those used at steam electric stations, by several methods; the main one being the removal of the fouling growth at intervals by use of a biocide, heat treatment, and/or mechanical scrubbing. The most common method is the use of chlorine. Basically, there are three ways to prevent/control fouling: exclusion of the organism, prevention of attachment, or cleaning of the surfaces after the fouling organisms have attached. All three methods are now being employed under different situations, and the one that is used is determined by system design needs, cost, and environmental constraints. The exclusion method is probably the least frequently used procedure for the prevention of fouling in circulating sea water systems. It is used where the volume of water needed is not high and there is an availability of sandy substrate. The general configuration is for the intake line to be located under the sand substrate and the water drawn through the sand; thereby filtering the organisms out of the water as it percolates through the sand. In the prevention method, the surface is coated with some type of toxic substance which inhibits the attachment of fouling, or a toxic material is added to the sea water to reduce 
the ability of organisms to attach. Under certain conditions, setting may be prevented by high water velocities. The Europeans, particularly in England, are using continuous low-level chlorination to prevent the attachment of mussels and some foulers in their power plants that use sea water. Antifouling toxic coatings are also used; the toxicant gradually leaches from a surface and prevents the organisms from setting. Because of the leaching process, there is a finite life to the toxic material within the system and; therefore, it eventually becomes noneffective, and fouling occurs. The best example of this method is the antifouling paint used on boat bottoms. A system that is somewhat similar to this is the use of metals that are toxic to marine organisms in high concentrations. Examples of this are the use of copper or copper/nickel alloys. With these, the surface remains clean for a significant period of time but, eventually, there is sufficient nontoxic material built up on the surface so that fouling occurs. The primary early foulers are phytoplankters and bacteria which form coatings that allow larger foulers to be isolated from the metallic surface.

Physical cleaning of the surface is commonly used where the fouling of the surface does not create a significant problem for the operation of a system, or where routine "down-time" and physical cleaning costs can be tolerated. In addition, there are two on-line mechanical methods now used for condenser cleaning in large steam electric stations; one is a Mann ${ }^{\otimes}$ brush and the other is an Amertap ${ }^{\otimes}$ system. In both of these systems, a projectile is sent through the tubes periodically to physically remove any fouling that has occurred. Although these methods do keep the heat exchanger tubes clean, the piping leading to and from the heat exchanger is still able to foul and, therefore, it is necessary to physically or chemically clean these surfaces recurrently.

Another method of cleaning is chemical. In this situation, fouling is allowed to occur and develop up to a certain point, and then chlorine or another biocide is added to the system to kill the fouling and have it slough off. This method works well if the fouling consists of organic matter, phytoplankters or soft fouling organisms with loose attachments; however, if the foulers are organisms such as barnacles, mussels and other encrusting type animals, the chlorine will kill them, but their shell will remain attached to 
the surface and continue to inhibit water flow and/or heat exchange efficiency. The general way to operate with a biocide is to periodically clean to prevent these hard foulers from growing to any size or becoming firmly attached.

In addition to the proactive prevention or cleaning methods that can be used to keep the surfaces clean, there are a number of natural phenomena that may, in fact, help inhibit or remove fouling organisms from any particular substrate in a heat exchange system. These include: periodic incursion of water of a salinity not tolerated by the organisms, thereby causing them to die; the periodic increase in temperature above the normal living range of the organisms; the periodic reduction of oxygen concentration to a point below which the animals can live; or operation of the system only during those periods of time when the larvae are not present in the water column and, therefore, not available to settle and grow on the system surfaces.

For fouling considerations there are two basic heat exchanger concepts. One is where the sea water is pumped from a source through a heat exchanger and then returned to the source. The other is where the heat exchanger is placed in the sea water, and the circulating fluid is something other than sea water. In the first case, you would have the potential for fouling in the piping and plumbing that leads to the heat exchanger and on the sea water side of the heat exchanger. In the second case, the fouling would be on the outer surface of a heat exchanger. In the former case, there are generally larger and more complicated surfaces to keep clean, but it is easier to control the environment within which the surfaces exist. In the latter case, there is a less complicated and smaller surface area for fouling, but it is difficult to control the environment of the surface.

In the case of circulating sea water to a heat exchanger and back to the bay, all three preventive methods are available. The organisms can be excluded and prevented from settling and/or periodically cleaned off. If desired, a combination of all three may be used, depending on the biological situation and a number of chemical and physical characteristics of the water used in the system. For example, if a porous, fine-grained sediment is available at a depth that would provide water of the correct temperature, then a subsand filter intake could be used. The sea water being pumped through the system would 
be relatively free of organisms and very little fouling would be expected. However, even under these situations there may be some bacteria and/or slime molds that could grow in the system and, therefore, periodic cleaning with a biocide or by mechanical means would be advisable.

With the circulating sea water system, a second possibility is to use a coarse screened intake to prevent larger organisms from entering the piping system and clogging the pumps or small orifices that may exist within the plumbing. With this system, continuous or periodic chlorination is needed as required by loss of heat exchange efficiency. Under this system there are hazards to periodic chlorination. Organisms could enter, set, and grow to a size where, even though they are killed by chlorination, there are hard parts left within the system which may create problems. However, the exact situation as to abundance of organisms, physical/chemical characteristics of the water and variability of the physical/chemical condition may reduce the potential for fouling very significantly during the season when the heat pump would be used.

With this latter circulating system, a number of preventative and/or cleaning methods would be available. They would include periodic chlorination or chlorination at a low level throughout specific time periods; placing the system where low salinity or fresh water is pumped through it in the spring, thereby killing marine organisms that have set over the winter months; or by shutting the system down and sealing it off during the summer to allow the contained water to become anoxic, thereby killing everything. The implementation of this system would be highly dependent on what the fouling scheme was for the particular area being used.

Preliminary survey of the data available on meroplankton from the Juneau area indicates that most of the hard fouler larvae are present in the water from April through June (Wing and Reid 1972). Therefore, the fouling problem during the remainder of the year could be reduced to bacteria and/or some occasional soft foulers that are present. Considering the general temperature of the water throughout most of the year is less than $8^{\circ} \mathrm{C}$, the growth rate of these organisms may be very limited. The cleaning problem, therefore, may be very minimal and/or sporadic and hard to predict accurately. Under this 
system, the following scenario could occur. The system is installed with a quarter-inch mesh screened intake, and water is pumped into a heat exchanger and then returned to the bay. The system is started up in late September or early October and runs for an entire winter. Based on the available information, very little fouling would occur and no antifouling measures would need to be taken. The system is shut down in early June and the water in the system allowed to become anoxic. Organisms that have settled in the system die, and when it is turned on the next October, the anoxic water is flushed out and the system is clean. Another aid in maintaining the cleanliness of the system is its composition of copper/nickel alloy. The shutting down of the system and allowing it to go anoxic would regenerate the surfaces where free copper would be available. Care would have to be taken to insure that when the system is anoxic there are not conditions that would allow a galvanic cell to be established and cause acceleration of corrosion.

In the second year of running, everything goes we 11 again, and there is no major fouling; heat exchanger efficiency stays up, and there is no pumping problem. The only activity that may have to be undertaken would be the annual cleaning of the intake screen to make sure that fouling organisms have not settled on it and blocked its surface area, thereby reducing pumping ability. In the third year, there is a late spawn of the barnacles or mussels, and an early cold spell causes an earlier than normal startup of the heat pump, providing a situation where larvae are available for setting. Being unaware that these organisms are present, no precautions are taken and they set with in the system and grow to a fairly good size throughout the winter. When the system is turned off the following spring and allowed to go anoxic (providing it was able to maintain itself throughout the year), these organisms would die. However, normally the barnacle tests will stay attached because of their gluing mechanisms, and the mussel shells will float free in the system. When a system is started up the following year, the barnacle shells there would inhibit heat exchange, reduce the flow and the pipe diameter. The shell debris from the mussels would be in the system and possibly clog the heat exchanger. Therefore, with this system, although one or more years of good operation may occur, the potential for nonfunction or becoming fouled at some point in time is 
always present. However, with periodic (i.e., annual) inspections of the system and some method for physically and/or chemically cleaning it, the system may function successfully.

A third type of system would have the heat exchanger in the bay and the heat transfer fluid circulating through the inside of the condenser. Only the outside of a fixed condenser is exposed to the marine environment. Under this situation, the system would probably work if the condenser could be easily removed from the water and physically cleaned by either manual scrubbing or chemical treatment. Here, experience would allow persons to know how of ten this would have to be done and the type of materials that would work effectively in reducing the fouling to a level that provides the needed heat transfer. The system could be a copper-based alloy which would have minimal fouling in one year's time, and chemical cleaning could renew its surface periodically. This system could also be one that used an antifouling coating with finite life which, similar to boat bottoms, could be periodically painted to restore the toxicity of the surface. One particular hazard of this system is that a structure placed in the water would be subjected to all the problems associated with an object being located in the bay or channel. As an example, if it is in too shallow a depth, ice scouring could take it away and/or large logs or floating objects could cause damage. In addition, the renewal of warm water to it would be dependent on the natural circulation of the area, and it may be depth limited from the point of easy handling or use.

In conclusion, on the surface it appears that the heat pump concept may be feasible, and that the fouling may not be a major problem. The factors that will determine the fouling influence would be: (1) the amount of fouling tolerable to the system as far as heat exchange coefficients are concerned, (2) the actual area in which it is going to be placed and the type of fouling present, (3) the density and seasonability of the fouling organisms that are present in the water, (4) the physical/chemical oceanography of the area and how this would impact the sustaining of the fouling system and how this coincides with the availability of fouling organisms, (5) the cost of installing some cleaning mechanisms such as chlorinator, and the cost of chlorinating at whatever rate is necessary to maintain clean surfaces, and (6) the ease with 
which the system could be dismantled and manually or physically cleaned to keep its pumping mechanism and heat exchange surfaces free and capable of delivering the heat exchange that is necessary.

For the proposed heating systems, three alternatives appear to be the most practicable: a heat exchanger placed in the water, a system that uses chlorine to remove fouling, and a system that uses a sand filter and chlorination. The use of the heat exchanger in the water will be dependent on the availability of the proper physical environment and the ease of doing periodic cleaning.

The use of chlorine can be accomplished with any one of a number of small chlorination systems that are available off the shelf. These systems cost from about $\$ 400$ and up, depending on the complexity of the controls required and the total quantity of chlorine to be delivered. Under normal circumstances, a delivered rate of approximately $4 \mathrm{ppm}$ chlorine into clean sea water will provide sufficient residual oxidant to $k i l l$ and remove soft marine foulers and slimes. Chlorination at a level to provide $1.0 \mathrm{ppm}$ residual for one hour has been a standard practice in steam electric station condensers (White 1972). Hard-she 11 foulers are best eliminated by continuous low-level chlorination at about $0.5 \mathrm{ppm}$ residual at the inlet (White 1972).

To accomplish a residual oxidant in sea water, the natural oxidant demand must be satisfied first. In sea water there are organisms and other chemicals that are reduced by $\mathrm{Cl}_{2}$, thus reducing the available oxidant for a unit volume of $\mathrm{Cl}_{2}$ added. A general average for clean sea water is $1.5 \mathrm{ppm}$. If the water is rich in organisms, the demand can be higher and, likewise, sea water low in organisms will have a lower demand. Therefore, to accomplish oxidant residual of $1.0 \mathrm{ppm}, 2.5 \mathrm{ppm} \mathrm{Cl} 2$ will need to be added. In the situation where one hour of cleaning is to be done three times a day in a system that uses $100 \mathrm{gpm}$, it would require that $0.002 \mathrm{lb}$ of $\mathrm{Cl}_{2}$ be added per minute. This would be accomplished by either the addition of $\mathrm{Cl}_{2}$ gas or a liquid containing sodium hypochlorite. In general, for low $\mathrm{Cl}_{2}$ use systems sodium hypochlorite is the preferred means of adding $\mathrm{Cl}_{2}$ to water.

Sodium hypochlorite is available in a wide range of "trade percent available $\mathrm{Cl}_{2}$ " concentrations. However, because of natural delay processes, it 
appears that a $10 \%$ trade solution is the most economical. For the Seattle area, $15 \%$ "trade percent available $\mathrm{Cl}_{2}$ " costs $\$ 17.45 /$ case of 6 gallons. However, this normally decays to a $10-11 \%$ solution on the shelf so, unless measurements of the actual quantities of $\mathrm{Cl}_{2}$ (as $\mathrm{HOCl}^{-}$) are made periodically for calculations of required delivery rates, one would need to assume a $10 \%$ solution to be on the conservative side.

For example, a system that uses $100 \mathrm{gpm}$ of sea water would require the $10 \%$ sodium hypochlorite solution to be added at a rate of $0.002 \mathrm{gal} / \mathrm{min}$ to accomplish a residual oxidant of $1.0 \mathrm{ppm}$. This calculates out to be approximately $0.14 \mathrm{gal} / \mathrm{hr}$ or, on the three times a day for one hour schedule, $140 \mathrm{gal} / \mathrm{yr}$. This figure is conservative and could be reduced by a number of factors: lower dose rate required because of natural demand, less frequent dosing, or higher $\mathrm{Cl}_{2}$ concentration in stock solution. Chlorination units capable of delivering the chlorine are made by a number of manufacturers.

Continuous dosing at $0.5 \mathrm{ppm}$ residual would require the addition of approximately $2 \mathrm{ppm} \mathrm{Cl}_{2}$ and, thus, use the same sodium hypochlorite solution at a rate of $0.0015 \mathrm{gal} / \mathrm{min}$ or $0.09 \mathrm{gal} / \mathrm{hr}$. For a three-month period this would require 194 gallons of solution.

The discharging of residual $\mathrm{Cl}_{2}$ or other oxidants is regulated by EPA. However, their current regulation is vague about where the residual is to be measured. If it is in the discharge pipe, the described system would not be legal without a special exemption. However, if an area of mixing is allowed, then the natural demand of the sea water in the discharge area would probably remove any residual $\mathrm{Cl}_{2}$ and bring the system within the EPA guidelines of $2.0 \mathrm{\mu g} / 1$ for salmonoid fish and $10.0 \mu \mathrm{g} / 1$ for other frashwater and marine organisms (U.S. Environmental Protection Agency 1976). However, applicable state laws and regulations would need to be reviewed to assure compliance.

The use of a sand filter is also an attractive method for elimination of fouling organisms. In this type of system a swimming pool type sand filter or a subsand intake structure is used to prevent most fouling organisms from entering the piping system. The use of a subsand intake would be dependent on the local sediment conditions. The use of a swimming pool type filter would 
have an initial cost of approximately $\$ 500$ to $\$ 1,000$, depending on the expected particulate load in the water and the volume of water required for the system. In addition to the filter, the pump would need to be strong enough to provide sufficient water with the head loss caused by the filter.

Filter systems require routine backflushing and periodic maintenance to clear foulers from the sea water side of the filter. The rate of backflushing is dependent on the sea water's particulate load and can vary from minutes to months. The backflushing can be manual or automated. In addition, the capability for slug chlorination should be included in the system to allow for periodic removal of slimes.

There is a limited amount of published temperature and salinity data available for the waters of interest to the project. The most complete and detailed information is for Auke Bay (Bruce et a1. 1977). This report provides a summary of selected physical and chemical characteristics of Auke Bay for the period 1961-1968. Figures 4.1 and 4.2 are taken from the report and provide a sumary of selected physical and chemical characteristics of Auke Bay for the period 1961-1968. Figures 4.1 and 4.2 are taken from the report and greatest temperature and salinity range $\left(<2^{\circ} \mathrm{C}\right.$ to $17^{\circ} \mathrm{C}$ and $2^{\circ} \%$ (parts per thousand) to $3 \%$, respectively). This variation decreased with depth, and at 50M the temperature range was from $2^{\circ} \mathrm{C}$ to $7.8^{\circ} \mathrm{C}$ and the salinity range $30^{\circ} \% 0$ to $31^{\circ} \% 0$. For temperature there appears to be very little change below 30M. Figures 4.3 and 4.4 are also from the report by Bruce et al. (1977) and show representative vertical profiles for temperature and salinity for the months January, April, July and October.

There appears to be even less data available on the seasonal abundance of fouling organisms larvae for the waters of interest. Only one publication could be located, and it is also for the Auke Bay region. The study by Wing and Reid (1972) was conducted from late fall of 1962 through January 1964. Their data indicates that the major hard foulers (barnacles and mussels) have larvae present in abundance in April, May, and June. In 1963 the mussel 1arvae were most abundant in May and June, and the barnacle nauplii (larvae) in April, May, and June. The average total numbers of zooplankton in the water column ranged from approximately $1 / \mathrm{M}^{3}$ in January to $438 / \mathrm{M}^{3}$ in June. In 


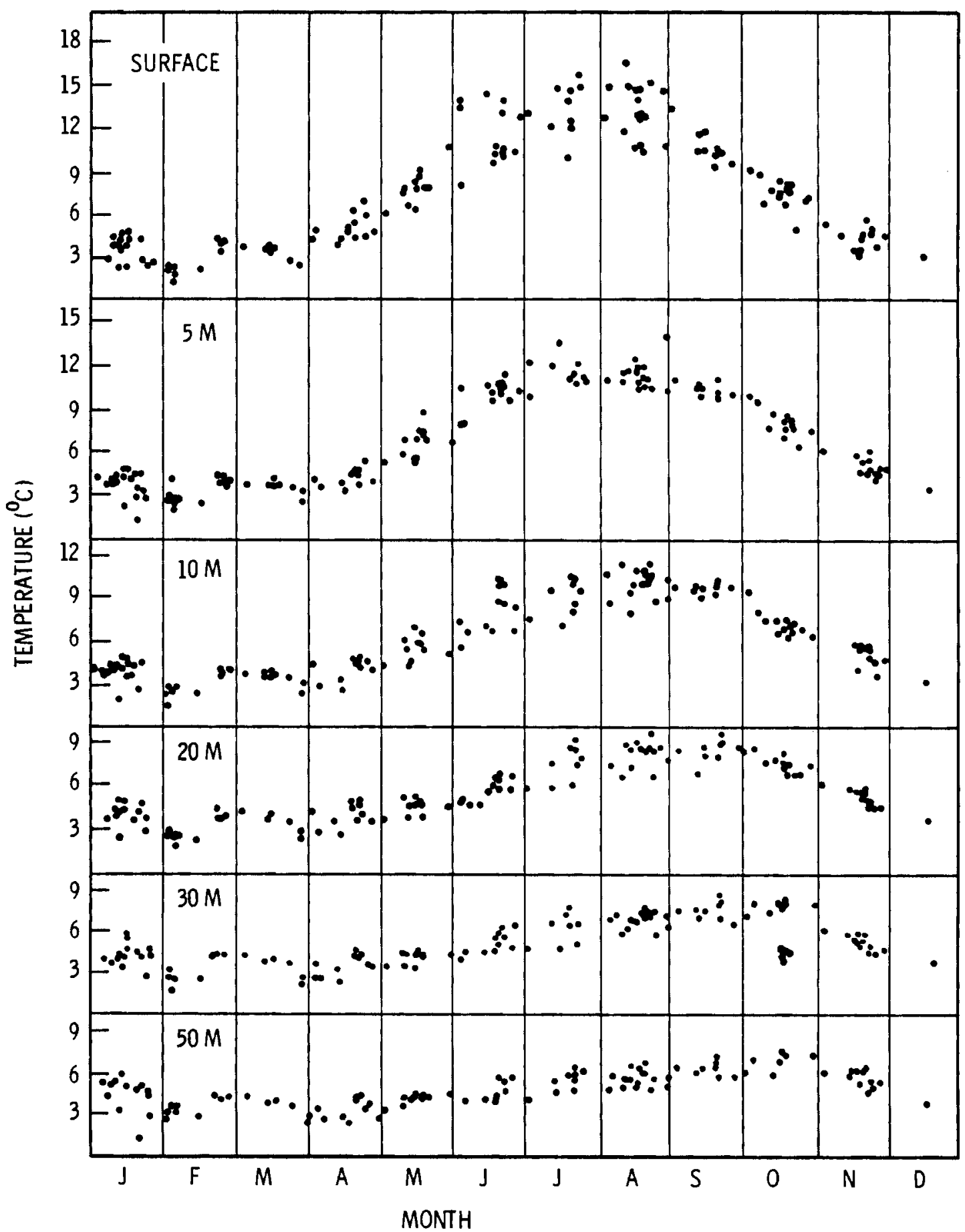

FIGURE 4.1. Observed Water Temperatures $\left({ }^{\circ} \mathrm{C}\right)$ at Selected Depths in Auke Bay, Alaska, 1960-1968

Source: Bruce 1977, p. 5. 


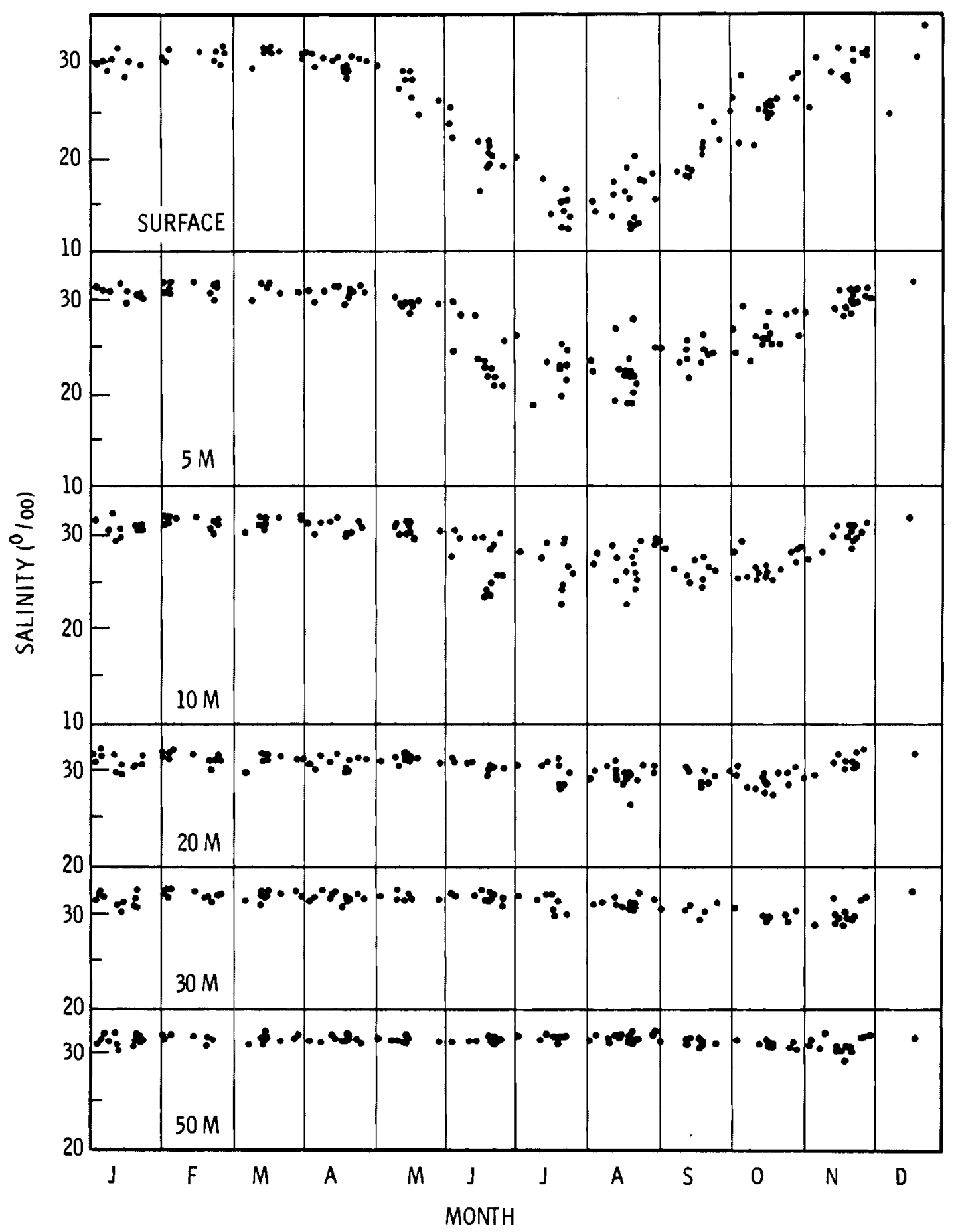

FIGURE 4.2. Observed Salinities $(\% / 00)$ at Selected Depths in Auke Bay, Alaska, 1960-1968

Source: Bruce 1977, p. 5. 


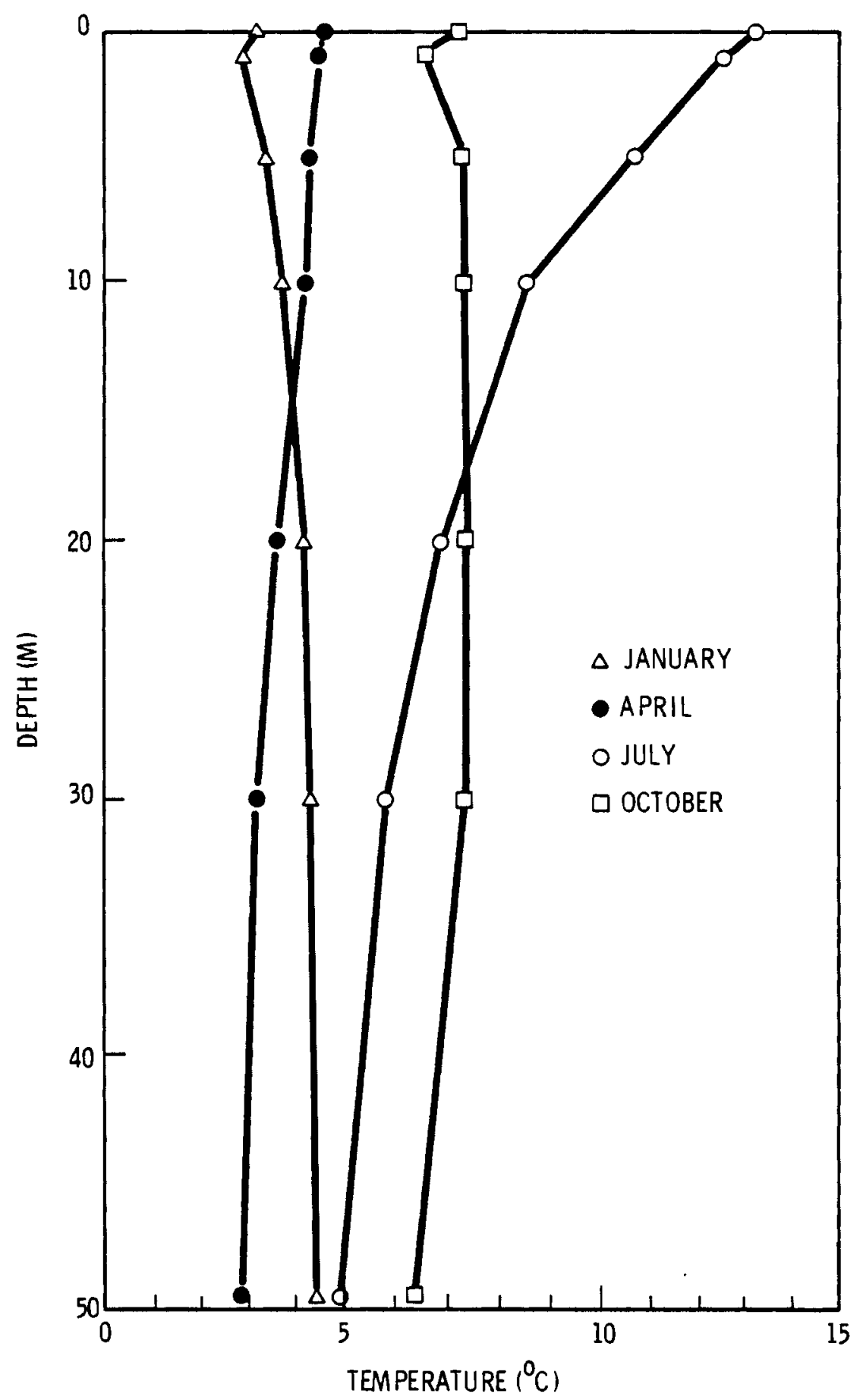

FIGURE 4.3. Typical Profiles of Temperature $\left({ }^{\circ} \mathrm{C}\right)$ in Auke Bay, Alaska, for January, Apri1, July, and October 1960-1968

Source: Bruce 1977, p. 5. 


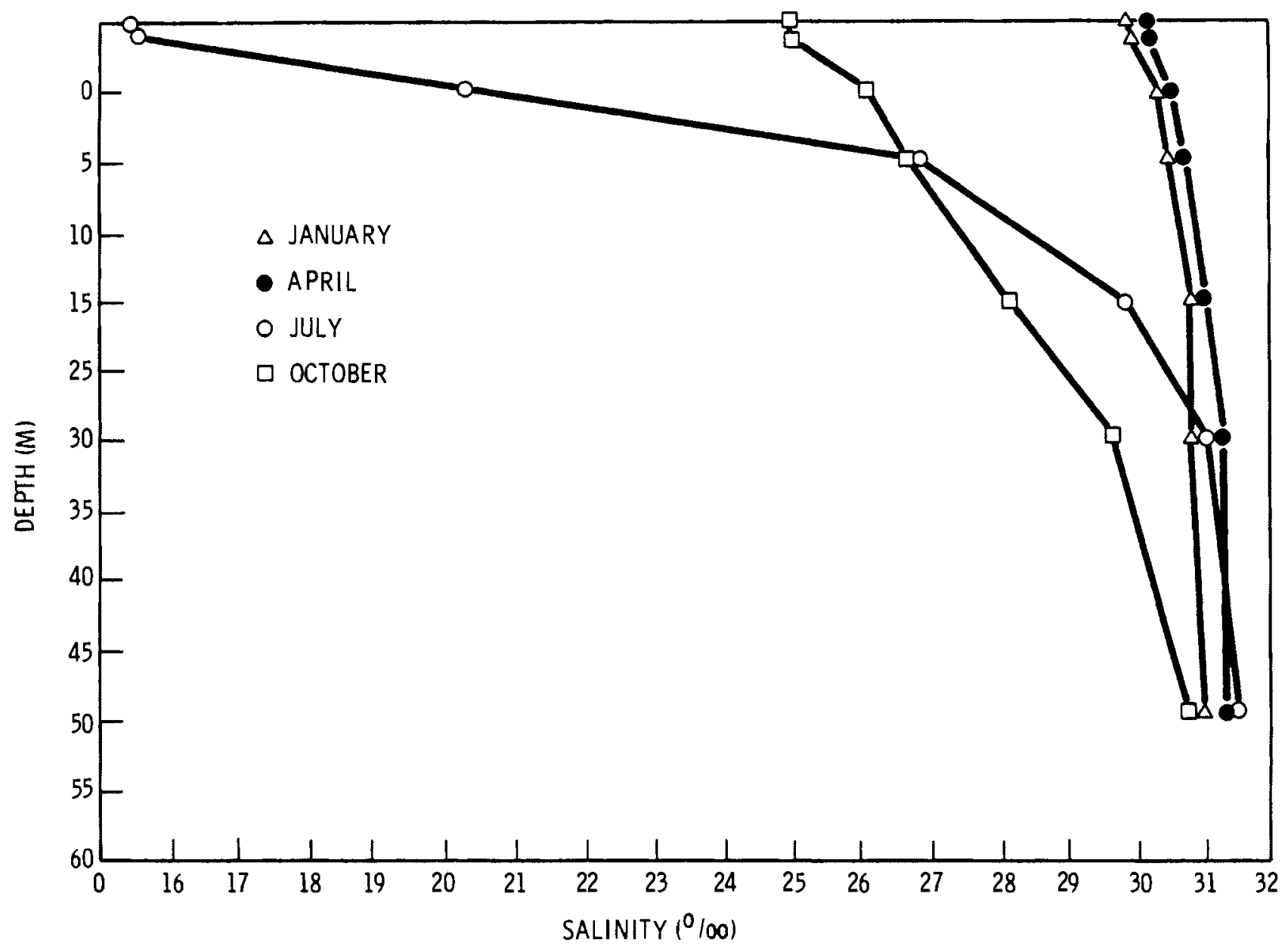

FIGURE 4.4. Typical Profiles of Salinity $(\% / 00)$ in Auke Bay, Alaska, for January, April, July, and October 1960-1968

Source: Bruce 1977, p. 5.

the period from April through June, barnacle nauplii make up almost one half of the total numbers of zooplankton collected (Wing and Reid 1972). Unfortunately, data for other years or geographic locations of interest were not available to determine how the time of appearance and abundance of those organisms varies.

\subsection{ASSESSMENT OF CORROSION PROBLEMS}

While marine fouling is the primary problem associated with the use of sea water as a heat source, the problem of corrosion must be addressed whenever 
sea water is used. In general, for this application, corrosion problems can be alleviated through the proper selection of piping and heat exchange materials. PVC piping and fittings can be used throughout the sea water handling system. The only places where metal components are required are in the pump and the heat exchanger.

According to Laque $(1975$, p. 257$)$ the choice of materials for piping for sea water systems should be based on the following criteria:

1. Ability to resist general and localized corrosion such as pitting and impingement attack throughout all the flow velocities that may be encountered. This range extends from prolonged stagnation in dead end lines to the high degree of localized turbulence created downstream of elbows, downstream of partially throttled valves, or adjacent to pump discharges.

2. Galvanic compatibility with metals used for associated components such as valve bodies and pump casings.

3. Freedom from fouling by macro marine organisms such as barnacles, mussels, and hydroids.

4. Amenability to fabrication by conventional practices including pipe bending, welding, and brazing.

He goes on to say:

The alloy that satisfies all of these criteria to the greatest extent is the $90 \%$ copper $10 \%$ nickel alloy containing about $1.25 \%$ iron as covered by ASTM designation B-466-68 for seamless pipe and ASTM designation B-467-68 for welded pipe (Laque 1975, p. 257).

Fortunately, copper-nickel is the most commonly used metal for use in heat exchangers in WSHPS. Either a $90 \%$ copper $10 \%$ nickel with $1.25 \%$ iron or a $70 \%$ copper $30 \%$ nickel alloy with $1.0 \%$ iron should be specified for any sea water heat pump application. Typical corrosion rates for copper-nickel alloys in sea water are on the order-of-magnitude of 0.1 to 0.5 mils per year (Laque 1975, p. 146). To reduce corrosion to a minimum the limiting design velocities shown in Table 4.1 should be used. 
TABLE 4.1. Suggested Limiting Design Velocities for Copper Alloys in Sea Water Piping Systems

\begin{tabular}{cccc} 
Alloy & \multicolumn{3}{c}{ Limiting Design Velocity $(\mathrm{ft} / \mathrm{sec})$} \\
Pipe Sizes
\end{tabular}

Source: Laque 1975, p. 258.

Corrosion could be a problem for submersible pumps of metallic construction operating in sea water. At the NMFS Auke Bay Laboratory submersible pumps are used to circulate sea water through the sea water piping system. Experience with submersible pumps in this application has not been entirely successful. Pumps typically last approximately two years before they must be replaced. In the majority of the cases pump failure is caused by electrical problems. The pumps used at the Auke Bay Laboratory are designed for sea water application. They have cast iron bodies with stainless steel impellers and shafts. (a) One pump manufacturer indicated that one could expect 5 to 10 year lifetimes from submersible pumps operating in sea water. (b)

There could be several reasons for this discrepancy: 1) the corrosiveness of the water at Auke Bay, 2) the nature of the specific application at Auke Bay, or 3) differences in the design of the specific pumps. Little effort was made to resolve these differences as part of this project. However, any application using submersible pumps in sea water should be carefully evaluated. It appears that one good solution to the problem of corrosion in sea water pumps is to use centrifugal or jet pumps which are not submersed in the water. In many cases these types of pumps are available with non-metallic components that eliminate the problem of corrosion in the pump itself. The problems with salt water spray getting into the electric motor remain, but they are reduced.

\footnotetext{
(a) Discussions with John Kinney, Alaska Regional Engineer, NMFS, May 30-June 2, 1980.

(b) Discussions with Steve Phiefer, Peabody Floway Pumps, Fresno, Calif., May 29, 1980.
} 
Bruce, H. E., D. R. MCLain, and B. L. Wing. 1977. Annual Physical and Chemical Oceanographic Cycles of Auke Bay, Southeastern ATaska. Technical Report NMFS SSRF-712, NationaT Marine Fisheries Service, Washington, DC.

Laque, F. L. 1975. Marine Corrosion: Causes and Prevention. John Wiley \& Sons, New York, NY.

U.S. Environmental Protection Agency. 1976. Quality Criteria for Water. U.S. Environmental Protection Agency, Washington, DC.

White, G. C. 1972. Handbook of Chlorination. Van Nostrand Reinhold, New York, NY.

Wing, B. L. and G. M. Reid. 1972. Surface Zooplankton from Auke Bay and Vic inity, Southeastern Alaska, August 1962 to January 1964. U.S. Dep. Commer., NatT. Oceanic Atmos. Admin., NatT. Mar. Fish. Serv., Data Rep. 72, $765 \mathrm{pp}$. 


\subsection{CONCEPTUAL DESIGN OF WATER SOURCE HEAT PUMP HEATING SYSTEMS}

\subsection{INTRODUCTION}

To make a more realistic economic evaluation of WSHPs relative to other types of heating, 4 case studies were performed. Each case involves a building type and a preliminary design for a WSHP heating system. The buildings and heating systems were selected to be representative of the current Juneau residential and commercial building stock for which WSHPs appear to provide a viable alternative heating method.

The buildings selected were:

1. Typical new Mendenhall Valley residence.

2. The filter building located at the Auke Bay Laboratory of the National Marine Fisheries Service (NMFS)

3. The warehouse located at the subport facilities of the NMFS

4. The salmon hatchery located near the Snettisham hydroelectric project.

The building used as an example in Case 1 does not presently exist. The size, floor plan, and type of construction were chosen to be representative of typical new construction in the Mendenhall Valley area. Cases 2 and 3 involve buildings which presently exist. Construction was started on the Snettisham fish hatchery (Case 4) during May 1980.

In Case 1 ground water is assumed to be used as the heat source, in Cases 2 and 3 sea water is assumed to be the heat source, while in Case 4 lake water from the tailrace of the Snettisham hydroelectric project is used as the heat source.

In the first three cases heating load estimates were made. In the case of the fish hatchery the design heat loads prepared as part of the design package were used directly. Using the calculated heat loads as a basis, WSHP based heating systems were designed for each case. 
In Section 5.2 each of the case studies is presented. In Section 5.3 the heat load methodology and results of the heat load calculations are presented. In Section 5.4 the heating systems using WSHPS are presented for each of the 4 cases.

\subsection{BUILDING DESIGNS AND HEAT PUMP SYSTEMS}

\subsubsection{New Residential Construction in the Mendenhall Valley}

This case evaluates a typical new residence in the Mendenhall Valley area. The structure is a two-story, split entry home with an attached garage. There are $1290 \mathrm{sq}$. ft of living space on the upper level and $530 \mathrm{sq}$. ft on the lower leve1. The floor plan is shown in Figure 5.1. The number and letter designations in Figures 5.1 through 5.6 refer to information about the doors and windows, respectively, necessary for the heat load calculations in Appendix $B$.

The exterior walls are assumed to have $2 \times 6$ studs insulated with $51 / 2$ in. fiberglass batts to a value of $R-19$. The ceiling is assumed to be insulated to a value of $R-38$ (approximately 12 in. of fiberglass). All windows are to be double glazed aluminum frame with a thermal barrier. The perimeter of the foundation is insulated with 1 //2 in. of rigid insulation.

As mentioned above, a WSHP using ground water is used as a heat source for comparative purposes. The high ground water table (about $20 \mathrm{ft}$ below the surface) in the Mendenhall Valley is an attractive source of heat for WSHPs since pumping head losses (and, therefore, pumping costs) are low. In addition, there appears to be an ample supply of water for at least a moderate number of WSHP applications. The temperature of ground water in the Mendenhall Valley area is generally between 40 and $46^{\circ} \mathrm{F}$ (McConaghy 1969, p. 57-59). Water temperatures in this range are relatively low for use with WSHPS but are acceptable. (a) The chemical composition of the water also appears to be acceptable (McConaghy 1969, p. 57-59). (b)

\footnotetext{
(a) Discussions with WSHP manufacturers and WSHP manufacturer's descriptive literature, March-April 1980.

(b) At this point it is important to note that the temperature and chemical composition of the water to be used in a WSHP should be carefully evaluated on a case-by-case basis before a WSHP heating system is installed.
} 


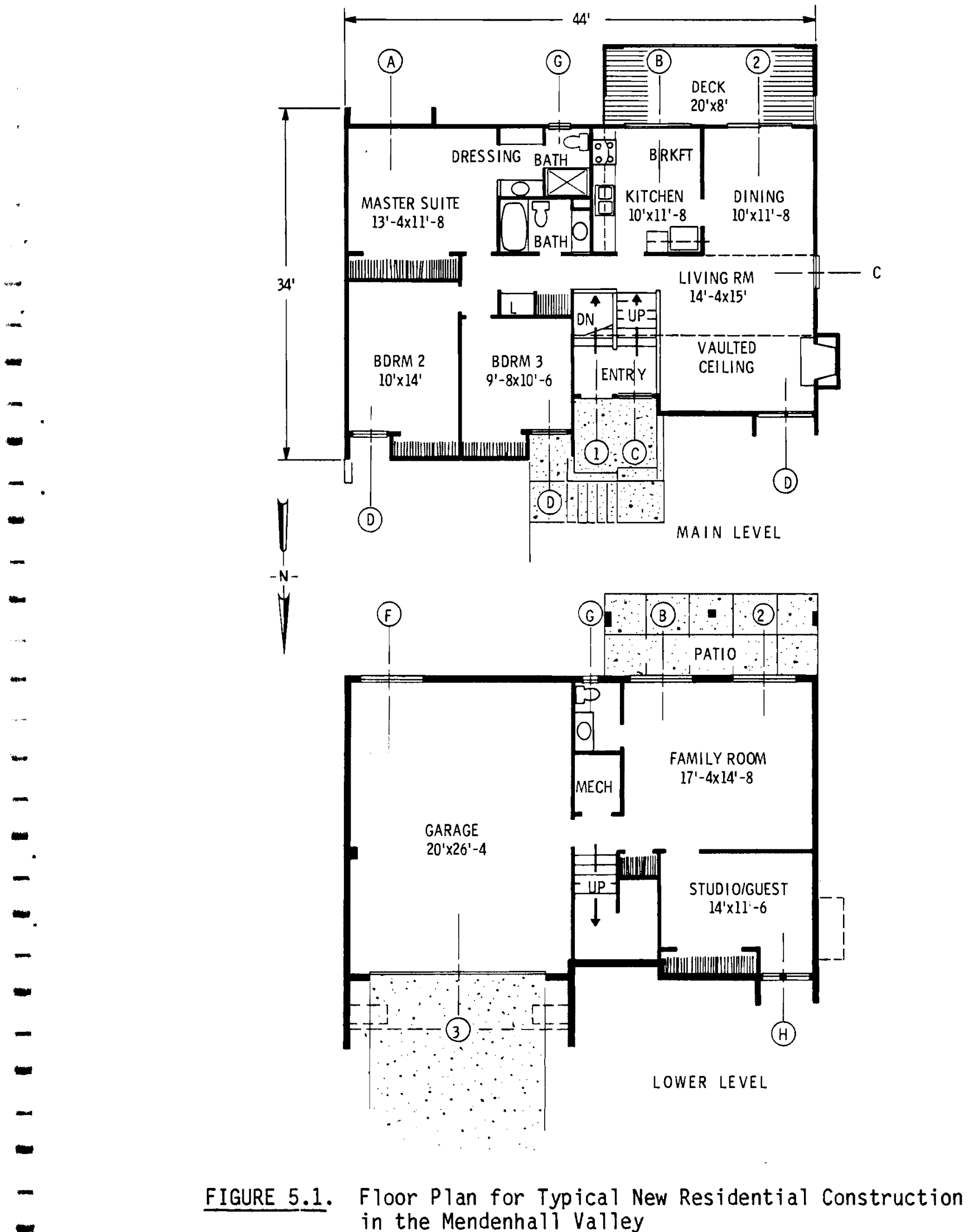
in the Mendenhall Valley 


\subsubsection{Filter Building at the Auke Bay Laboratory}

This case evaluates the use of a residential sized heat pump to heat an existing building at the NMFS Auke Bay Laboratory. The "filter building" is a one-story frame structure which is used to house sand filters and the fresh water storage tanks, and for storage. While it is relatively small (704 sq. ft), it has a relatively high design heat load typical of new residential buildings. The floor plan for this building is shown in Figure 5.2.

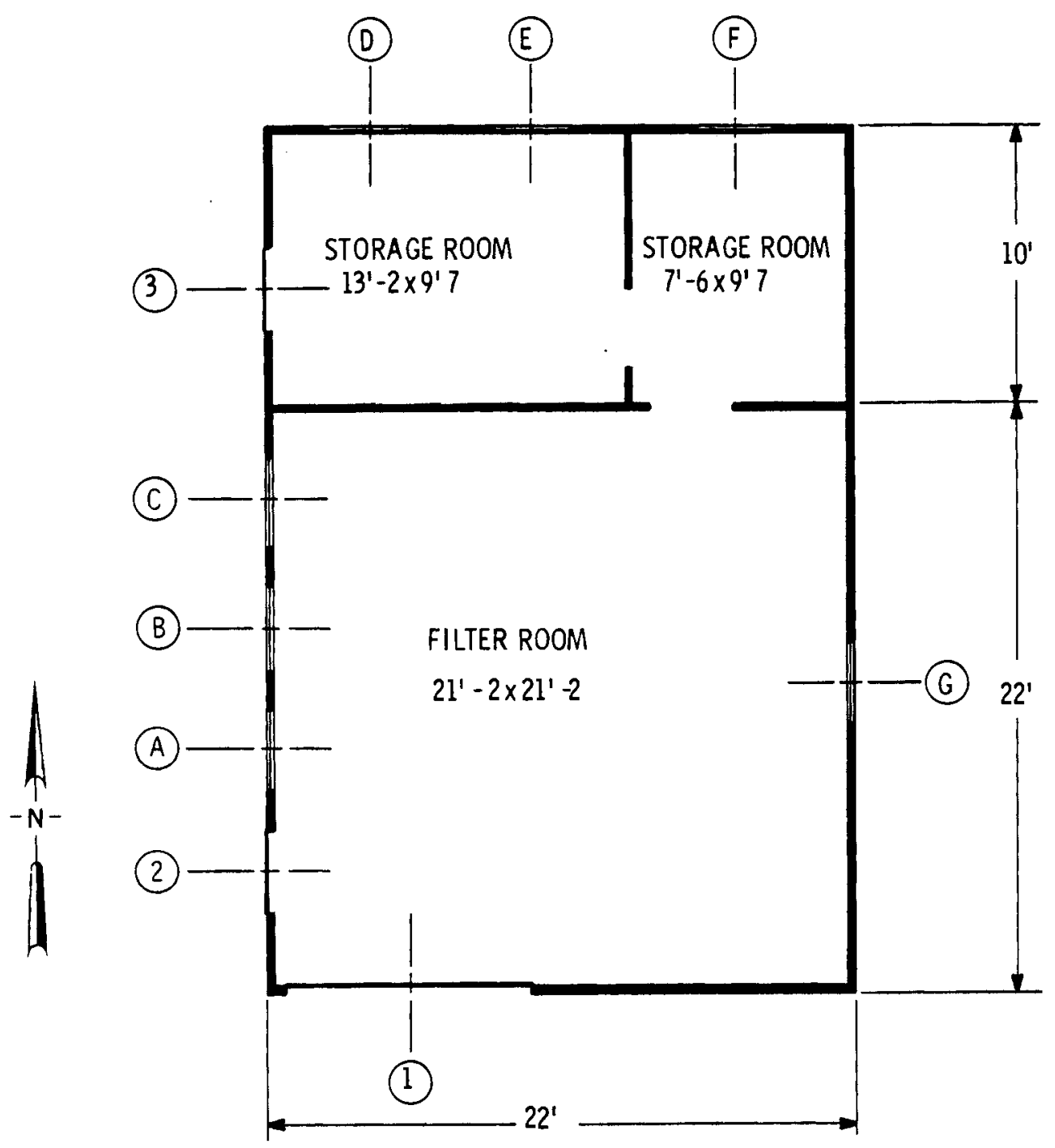

FIGURE 5.2. Floor Plan for Filter Building at Auke Bay Laboratory 
The exterior walls have $2 \times 4$ studs. All walls except the west wall of the filter room are insulated with $31 / 2$ in. fiberglass batts. The ceiling is also insulated with $31 / 2$ in. fiberglass batts. The windows are single glazed and are non-opening. The building is set on blocks approximately 8 in. above the ground level. There is no floor insulation.

In this case sea water is used as a heat source. The Auke Bay Laboratory has an existing sea water handling system with a capacity of about 125 gallons per minute $(\mathrm{gpm})$. A portion of this water would be taken from the seawater piping system, used as a source of heat, and then returned to the effluent sysem. The water will be obtained in the main laboratory building which is located about $15 \mathrm{ft}$ south of the filter building. The water is assumed to be piped around the east and north sides of the building to the heat pump which will be located in the larger room. With the present system the seawater is filtered using sand filters to remove fouling organisms.

The presence of the existing seawater handling system makes this application an attractive demonstration for a system using seawater as a heat source. While the water may pick up a small amount of heat as it flows through the fish tanks, or wet lab area, it should not have any significant effect on the performance of the heat pump for demonstration purposes.

The use of seawater as a source of heat for WSHPs was discussed earlier in Chapter 4. In fact, much of the data about seawater presented in Chapter 4 was obtained from the Auke Bay area.

\subsubsection{Warehouse on Juneau Waterfront}

This case involves a WSHP heating system using seawater as a heat source to provide heating for a warehouse/shop building at the subport facilities of the NMFS. This is a Butler building with outside dimensions of about $60 \mathrm{ft}$ by $120 \mathrm{ft}$. The floor plan for this building is shown in Figures 5.3 and 5.4. As shown the building serves as a combination warehouse, garage, and shop building. The building is immediately adjacent to the dock and is about $60 \mathrm{ft}$ from sea water in the Gastineau Channel.

All exterior walls and the ceiling are formed by sandwich panels composed of painted galvanized steel on the exterior and interior with a core of approximately 1 in. of polyurethane foam. The estimated $R$ value of this wall 


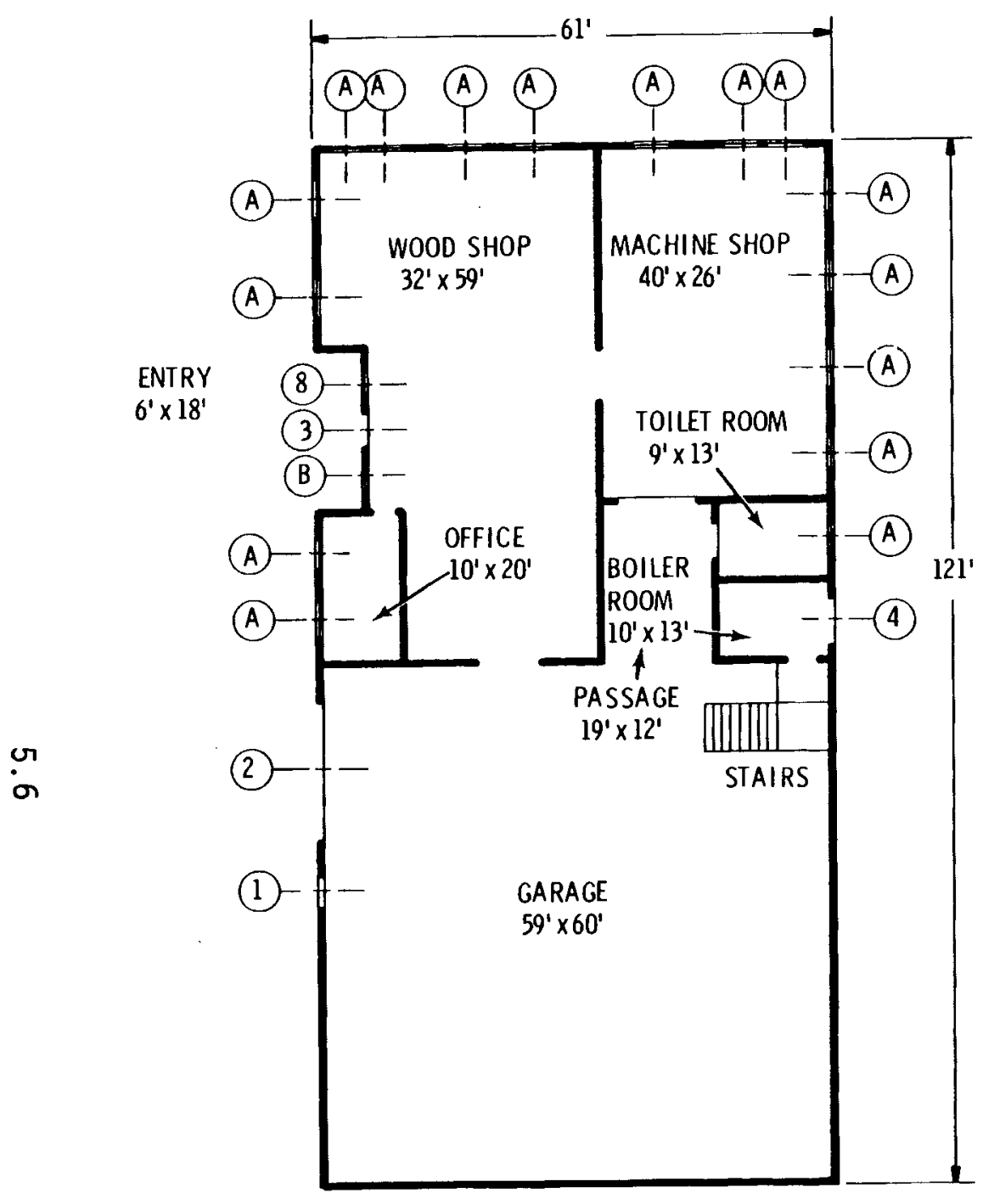

FIRST FLOOR

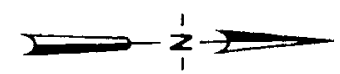

FIGURE 5.3. Floor Plan for First Floor of Warehouse on Juneau Waterfront

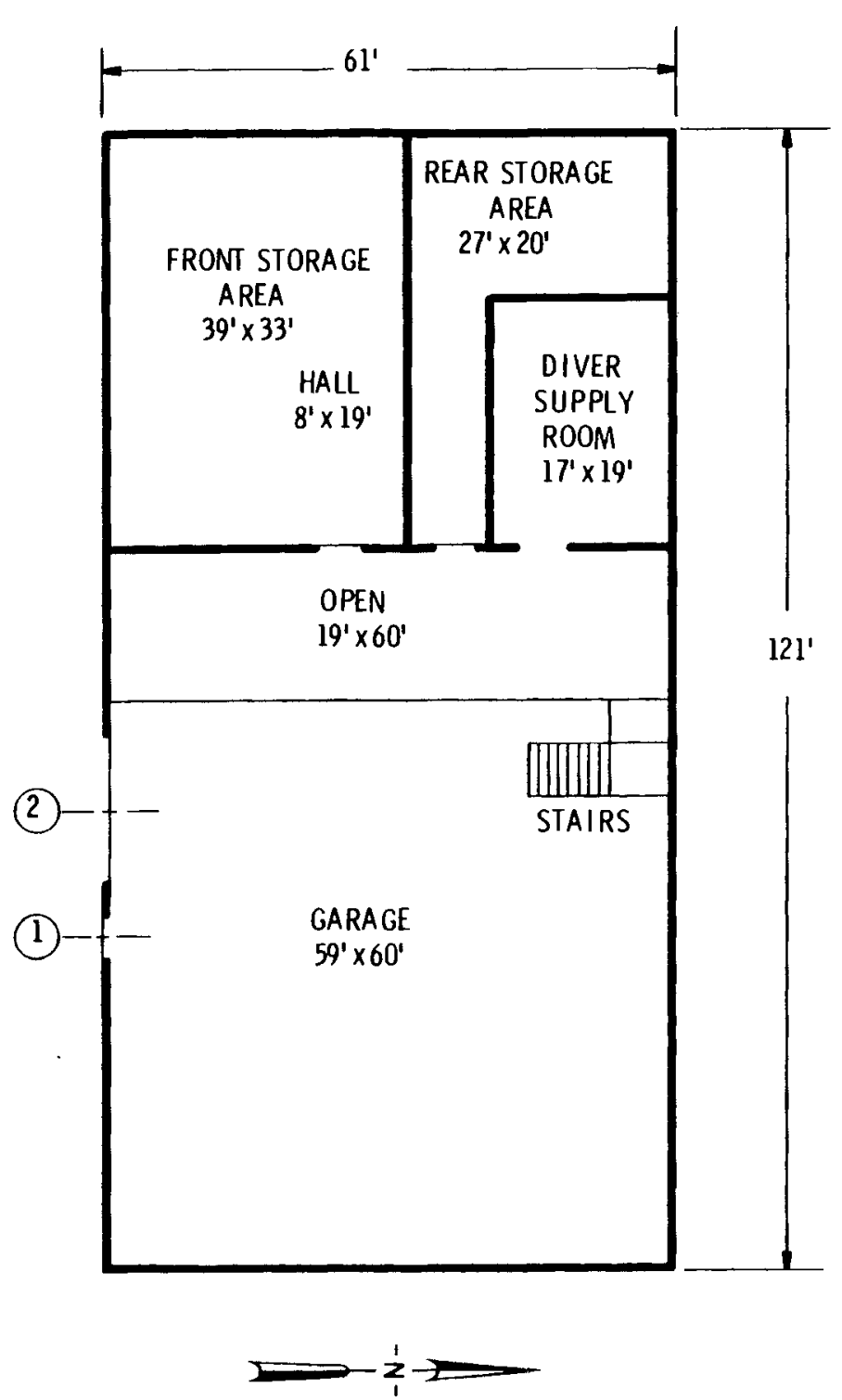

FIGURE 5.4. Floor Plan for Mezzanine of Warehouse on Juneau Waterfront 
structure is 10 (a) The walls of the rooms on the lower level are furred out about $12 \mathrm{in}$. but do not include any additional insulation. The building has a poured concrete floor with no edge insulation.

In this case sea water is used as a heat source. An intake structure containing a submersible pump would be located below the pier. Water supply lines would run from the intake below this pier dock, along the north side of the building, and to a hydrotank located under the stairs in the garage area of the building. Intermittent chlorinatione would be used to kill any fouling marine organisms. Three single package unitary WSHPs are used in the design. The disposal piping would return the water along a similar route to the channe?.

\subsubsection{Salmon Hatchery Near Snettisham Hydroelectric Project}

This case considers the use of WSHPs to heat the Snettisham salmon hatchery which is to be built for the Alaska Department of Fish and Game during the summer and fall of 1980 . This structure will have a single story and include office, shop, laboratory, incubation, and egg handling and storage rooms. The floor plan is shown in Figures 5.5 and 5.6. While the building has over $9000 \mathrm{sq}$. ft its heat load is relatively low because the majority of the building is only to be heated to $45^{\circ}$. The exterior walls will have $3 \times 6$ framing with $51 / 2$ in. fiberglass batt insulation. The ceiling will have about 12 in. of fiberglass insulation.

In most cases in Alaska the surface water is too cold for use as a heat source for a WSHP. In this case, however, the water comes from the tailrace of the Snettisham hydroelectric facility. This water is taken from Long Lake and is heated slightly as it goes through the tunnel and generator turbine. The water temperature is about $41^{\circ} \mathrm{F}$ throughout the year.

In this case three single package unitary WSHPs are used to heat the building. The water will be taken from the incubation room water supply headboxes. Cooled water would be discharged to the building drain system.

(a) Discussions with Mike McGuire, Engineered Structures Inc., Richland, Washington, April 17, 1980. 


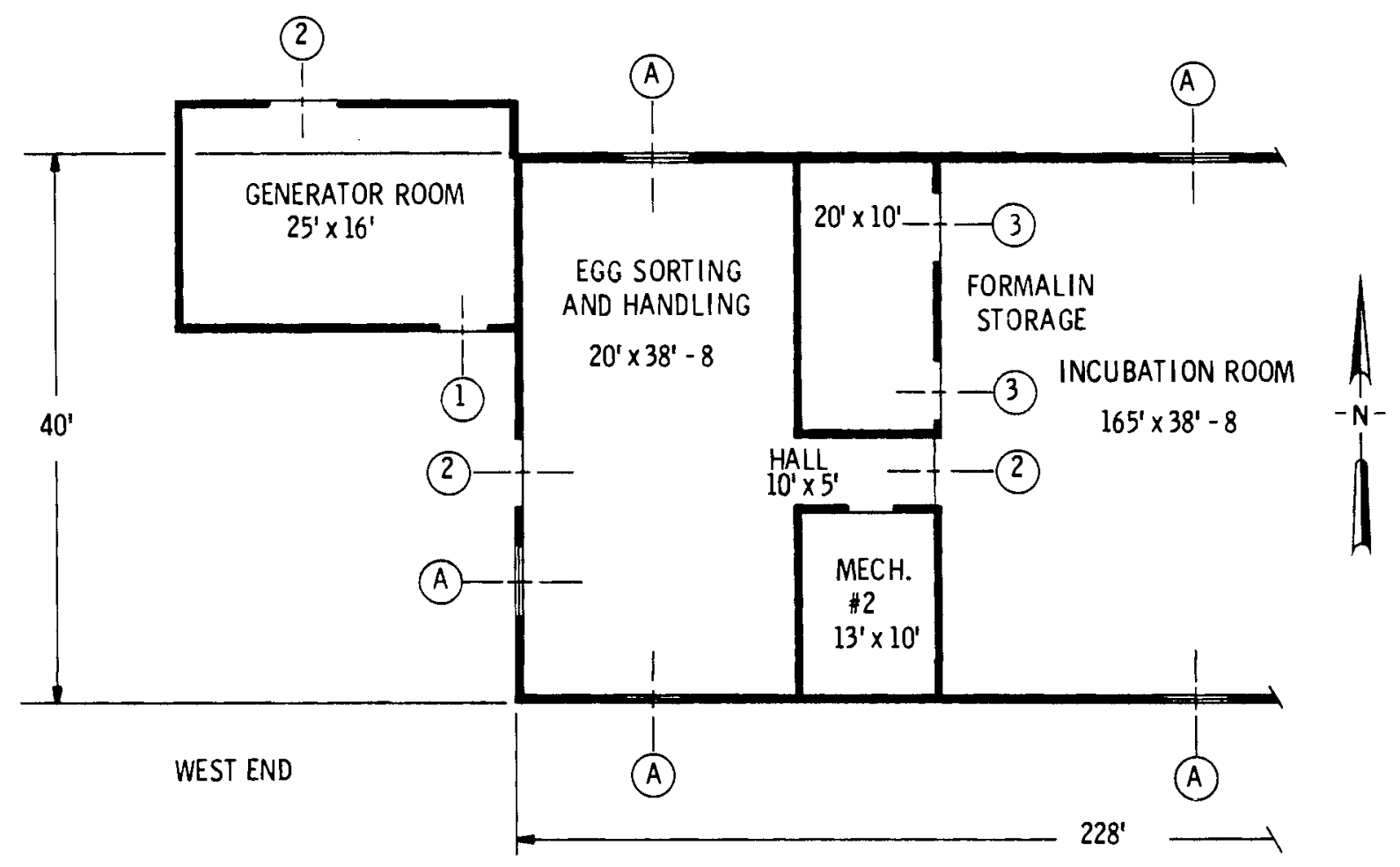

FIGURE 5.5. Floor Plan for West End of Snettisham Salmon Hatchery

(1)

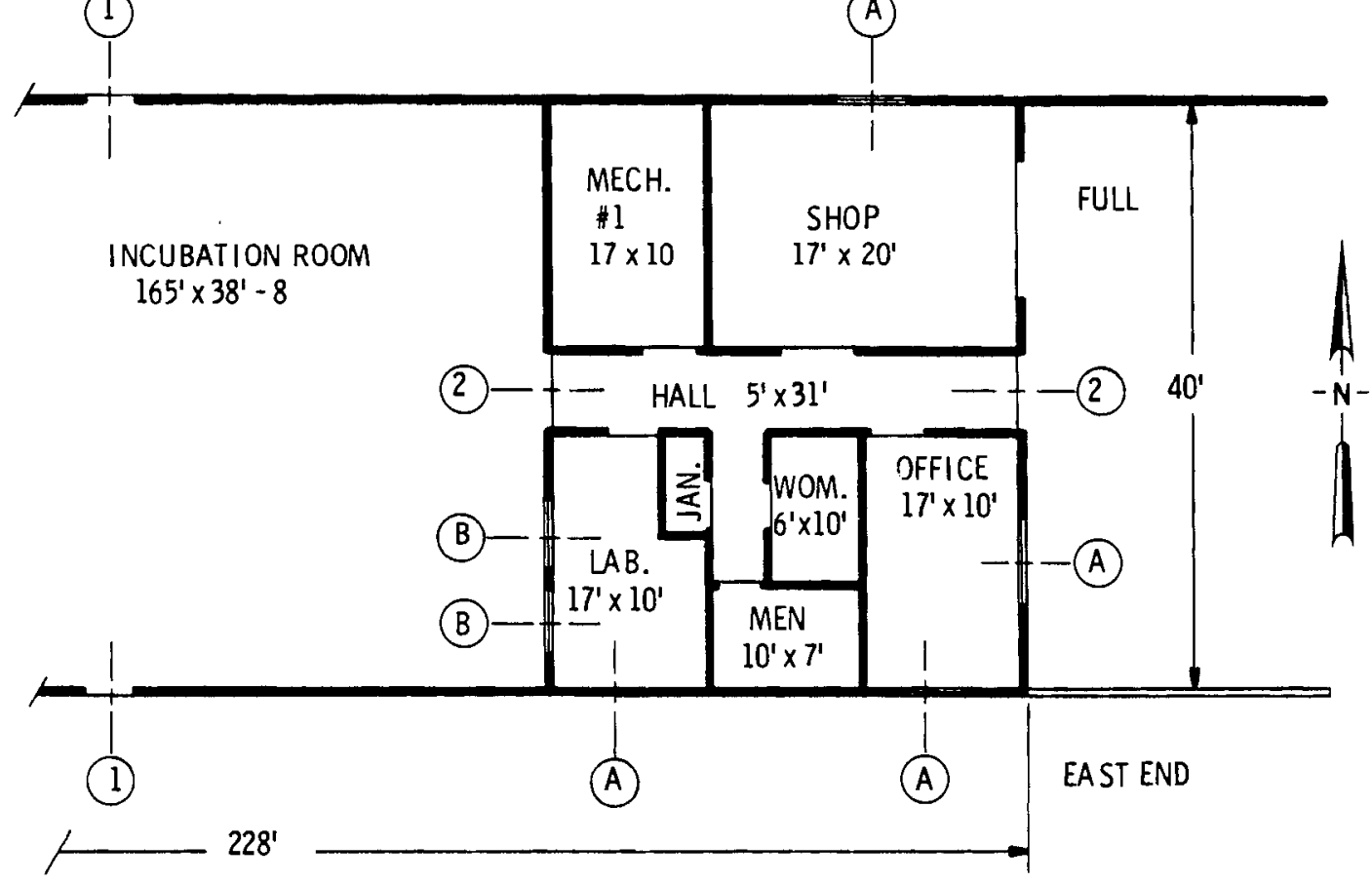

FIGURE 5.6. Floor Plan for East End of Snettisham Salmon Hatchery 


\subsection{HEAT LOAD METHODOLOGY AND ANALYSES}

Once the structural and heat transfer characteristics of the buildings to be evaluated have been determined the next step is to calculate the heat load for the building at the heating design conditions for the area in which the building is located. The heating design conditions refer to the conditions that give the maximum heat load that would be expected to normally occur in an area. For the Juneau airport the outdoor design temperature is $-5^{\circ} \mathrm{F}$ (ACCA 1975, p. 27). The design temperatures commonly used for other locations in the Juneau area vary. The outdoor design temperatures used in the 4 cases evaluated in this report are presented in the second column of Table 5.1.

The other temperature necessary to compute the design heat load is the indoor temperature that is to be maintained. For a residence this temperature is commonly $70^{\circ} \mathrm{F}$. The indoor design temperatures used in this analysis are presented in the third column of Table 5.1. In some cases different parts of a building may have different indoor design temperatures (the Snettisham salmon hatchery, for example). The difference between the outdoor and the indoor design temperatures is the design temperature difference which is used to compute the heat loads (Column 4 in Table 5.1).

TABLE 5.1. Summary of Assumptions and Results of Heat Load Calculations

\begin{tabular}{|c|c|c|c|c|c|}
\hline \multicolumn{2}{|r|}{ Case } & $\begin{array}{l}\text { Outdoor } \\
\text { Design } \\
\text { Temp. } \\
\left.{ }^{O} \mathrm{~F}\right) \\
\end{array}$ & $\begin{array}{c}\text { Interior } \\
\text { Design } \\
\text { Temp. } \\
\left({ }^{O} \mathrm{~F}\right) \\
\end{array}$ & $\begin{array}{c}\text { Design } \\
\text { Temp. } \\
\text { Difference } \\
\left({ }^{O} \mathrm{~F}\right) \\
\end{array}$ & $\begin{array}{l}\text { Heat Load } \\
\text { at Design } \\
\text { Condition } \\
\text { (Btu/hr) } \\
\end{array}$ \\
\hline 1. & $\begin{array}{l}\text { New Residential } \\
\text { Construction } \\
\text { Mendenhall Valley }\end{array}$ & -15 & 70 & 85 & 49,000 \\
\hline 2. & $\begin{array}{l}\text { Filter Building } \\
\text { Auke Bay }\end{array}$ & -5 & 60 & 65 & 57,000 \\
\hline 3. & $\begin{array}{l}\text { Warehouse } \\
\text { Subport-Juneau }\end{array}$ & -5 & 60 & 65 & 214,000 \\
\hline & $\begin{array}{l}\text { Fish Hatchery } \\
\text { Snettisham }\end{array}$ & -20 & $\begin{array}{l}45 \\
70\end{array}$ & $\begin{array}{l}65 \\
90\end{array}$ & $\begin{array}{r}159,000 \\
69,000 \\
\end{array}$ \\
\hline & & & & Total & 228,000 \\
\hline
\end{tabular}


Generally, calculation of the design heat loads for any structure involves determining the areas and insulating value of all exterior surfaces (exterior walls, windows, and doors) exposed to the outside air. Knowing the temperature difference existing across these surfaces at design conditions then allows the heat loss per sq. ft of surface area for each of the exterior surfaces to be determined. The heat losses for each surface are then added together to yield the total heat loss for the structure. Allowances are also made for air infiltration around windows and doors as well as for normal opening and closing of the windows and doors. The procedures to determine heat loads for structures are quite common and easy to use. The methodology used to compute the heat loads in this report is presented in a report published by the Air Conditioning Contractors of America (ACCA 1975).

The design heat loads for the structure evaluated in this report are presented in the 5th Column of Table 5.1. The detailed heat load calculation work sheets for the first three cases are presented in Appendix $B$. The design heating loads for the Snettisham fish hatchery were obtained from the mechanical contractors. These are also presented in Appendix B.

\subsection{HEAT PUMP SYSTEM DESIGNS}

Heating systems using WSHPS for space heating were designed for each of the example buildings. Water sources appropriate to each structure were used: fresh water from a shallow aquifer for the Mendenhall Valley residence, sea water from the Auke Bay Laboratory sea water supply for the filter building, sea water taken from Gastneau Channel for the subport warehouse, and fresh water from the Snettisham hydroelectric facility tailrace for the fish hatchery. In each case the temperature of the water source would be approximatly $40^{\circ} \mathrm{F}$, near the lower limit for WSHPs, and somewhat limiting the availability of suitable units.

A forced air heat distribution system was used in all cases because water-to-water heat pump units capable of delivering condenser water at temperatures adequate for satisfactory operation of convection heating terminals when operating on $40^{\circ} \mathrm{F}$ source water are not presently commercially available. Currently available water-to-water units are capable of delivering water at temperatures satisfactory for radient heating applications; radient heating 
designs however, were not within the scope of this study. Development is underway on "cascaded" heat pumps using staged refrigeration cycles. Such machines might be capable of providing condenser water of sufficiently high temperature to permit use of convection heating terminals.

The designs arrived at in this study are not necessarily optimum. They represent first iterations on the respective design problems and could likely be improved from both technical and economic standpoint by further analysis. Design considerations warranting additional analys is include air distribution system and water supply system pressure drops. Figures showing the piping and ductwork designs for each of the 4 cases are presented in Appendix $C$.

\subsubsection{Mendenhal1 Valley Residence}

Heating System Design

The heating system for the Mendenhall Valley residence uses a nominal 60,000 Btuh heating capacity WSHP supplied by fresh water obtained from the shallow aquifer underlying the Mendenhall Valley. Heat distribution is by a forced warm air system using extended plenum distribution. Wall thermostat control is provided.

The heat pump, located in the mechanical room (Figure 5.1 and C.2, Appendix $($ ), is an upright single-package heat-only unit rated at 50,000 Btuh with $40^{\circ} \mathrm{F}$ inlet water temperature. This is adequate for the design heat load of 47,000 Btuh (Table 5.1). This unit is equipped with integral condenser and blower, air filter and water flow control values. No backup resistance heating is provided in accordance with standard WSHP design practice.

Fifteen gpm of $40^{\circ} \mathrm{F}$ water is required at design operating conditions. Water is provided by a well system serving both domestic and heating needs. This system consists of a 30 foot deep, four inch diameter drilled we 11 equipped with a submersible pump capable of supplying $30 \mathrm{gpm}$ at $60 \mathrm{psi}$. Pressure control is by hydrotank and pump control pressure switch (Figure C.1). Use of the submersible pump (though more costly than the shallow well pumps in common use in the Mendenhall Valley) is desirable because of the relatively high water flow rate required and reduced pumping power requirements. Water flow control is by integral water flow regulating valves: Discharged water is 
returned to the aquifer by an injection well. The heat pump water supply is provided with isolation and boiler drain valves for heat exchanger backflushing, a supply line strainer, and temperature and pressure instrumentation. Piping from the well to the house and from the house to the injection well is PVC. Interior piping is copper. All piping is insulated.

An extended plenum system is used to distribute heated air to occupied spaces (Figure C.2). Overhead supply registers are used in the lower level and floor registers in the upper level; typical of conventional warm air heating systems. Returns are provided on each floor. Ductwork is of galvanized steel using standard rectangular and round sections. Because of low differential air temperatures across the condenser, heat pumps commonly require a large airflow rate necessitating ductwork of relatively large cross-sectional area. This distribution system is based on 2150 CFM air flow at 0.3 inch water gage static head. A wall thermostat provides blower and compressor control.

\section{Cost Estimate}

The cost estimate for this design, based on new construction, is summarized in Table 5.2. Included are regional cost adjustments, contractor's overhead and profit and a contingency allowance of $7.5 \%$.

\subsubsection{Auke Bay Filter Building}

Heating System Design

The heating system for the Auke Bay filter building uses a WSHP supplied by sea water obtained from Auke Bay via the laboratory sea water system. Heat distribution is by a forced air system using extended plenum distribution. Wall thermostat control is provided.

The heat pump, located in the northwest storage room (Figure 5.2), is an upright single-package heat-only unit rated at 60,000 Btuh with $40^{\circ} \mathrm{F}$ inlet water temperature. This is adequate for the design heat load of 57,000 Btuh (Table 5.1). This unit is equipped with integral condenser and blower, air filter and water flow control valves. No backup resistance heating is provided. 
TABLE 5.2. Cost Est imate, Mendenhall

Valley Residence $(1980 \$)$

\begin{tabular}{|c|c|c|c|c|}
\hline Item & Labor & $\begin{array}{l}\text { Material } \\
\text { and } \\
\text { Equipment }\end{array}$ & Subcontracts & Total \\
\hline Ductwork and Accessories & 3360 & 1100 & & \\
\hline Water Supply and Recharge & 550 & 1310 & 1710 & \\
\hline Heat Pump & 390 & 4360 & & \\
\hline Electrical and Control & 30 & 40 & & \\
\hline Test and Balance & 180 & - & $\longrightarrow$ & \\
\hline Subtotal & 4510 & 6810 & 1710 & \\
\hline Contractors 0\&P(a) & $\underline{1920}$ & 680 & - & \\
\hline Subtotal, inc 0\&P & 6430 & 7990 & 1710 & 15,630 \\
\hline Contingency, $7.5 \%$ & & & & 1170 \\
\hline Tota 1 & & & & 16,800 \\
\hline \multicolumn{5}{|l|}{ Credit for conventional } \\
\hline water system & & & & 1300 \\
\hline Net Tota1 Cost & & & & 15,500 \\
\hline
\end{tabular}

(a) Contractor's overhead and profit: $10 \%$ on material and equipment, $42.6 \%$ on labor.

Seventeen gpm of $40^{\circ} \mathrm{F}$ water is required at design operating conditions. Water is taken from a sea water header in the "wet lab". An air break is provided between the laboratory sea water supply and the heat pump water system by use of a sump with float valve level control as suction for the water supply pump (Figure C.3). A self-priming multistage jet pump takes suction on the sump to supply $20 \mathrm{gpm}$ at $50 \mathrm{psi}$ pump discharge pressure. Pressure control is by air-loaded hydrotank and pump control pressure switch, located in the wet $1 \mathrm{ab}$ adjacent to the pump. A 1-1/4 PVC water supply line runs from the hydrotank to the north wall of the laboratory via the laboratory utilador, and thence underground to the filter building for a total sump-to-heat pump distance of approximatly 150 feet. Water is returned by the same route to the main sea water drain in the laboratory utilador. The water supply is provided 
with isolation and boiler drain valves at the heat pump for heat exchanger backflushing, a supply line strainer, and temperature and pressure instrumentation. Use of the filtered laboratory sea water supply should eliminate the need for anti-fouling chlorination. Supply and return piping and fittings are PVC; copper is used at the heat pump. The jet pump is a standard commercial model with body and impeller of plastic material. The air-load hydrotank is also a standard commerical model with a plastic water bag.

A extended plenum system is used to distribute heated air to the filter room and the two storage rooms (Figure C.4). Rectangular galvanized steel construction with vertical-face supply registers are used. A single return is provided low or the north wall of the filter room; transfer grills facilitate cold air return from the supply rooms. The distribution system is based on a 2325 CFM air flow at 0.3 inch water gage external static pressure. A wall thermostat provides blower and compressor control.

\section{Cost Estimate}

The cost estimate for this design, based on retrofit construction is summarized in Table 5.3. Included are regional cost adjustments, contractor's overhead and profit and contingency allowance of $10 \%$.

\subsubsection{Warehouse on the Juneau Waterfront}

\section{Heating System Design}

The heating system for the subport warehouse uses three WSHPs supplied by sea water taken at depth from Gastineau Channel via a pierside submersible pump. Two independent heating zones are established, each supplied by a reducing trunk forced air distribution system. Zone I includes the office, boiler room, woodshop and machine shop. One heat pump of 72,000 Btuh nominal heating capacity with wall thermostat control is provided. Zone II includes the garage and the entire mezzanine level. Two heat pumps of 72,000 Btuh nominal heating capacity, installed in tandem, are used. Staged control using room and outdoor thermostats is provided. The subport warehouse heating system is designed as a demonstration retrofit to be installed in conjunction with the existing heating system. As such the location of equipment may not be optimal.

The Zone I heat pump, an upright single package unit, is located against the north wall of the woodshop (Figure C.5). This is a heat-only unit rated 
TABLE 5.3. Cost Estimate, Auke Bay Filter Building (1980\$)

\begin{tabular}{|c|c|c|c|c|}
\hline Item & Labor & $\begin{array}{l}\text { Material } \\
\text { and } \\
\text { Equipment }\end{array}$ & Subcontracts & Total \\
\hline Ductwork and Accessories & 1890 & 630 & 90 & \\
\hline Water Supply and Return & 2670 & 1480 & 680 & \\
\hline Heat Pump & 470 & 4930 & -- & \\
\hline Electrical and Control & 120 & 180 & -- & \\
\hline Test and Balance & 210 & - & - & \\
\hline Subtotal & 5360 & 7220 & 770 & \\
\hline Contractors 0\&P(a) & $\underline{2280}$ & 720 & - & \\
\hline Subtotal, inc $0 \& P$ & 6430 & 7990 & 1710 & 16,350 \\
\hline Contingency, $10 \%$ & & & & 1640 \\
\hline Total & & & & 17,990 \\
\hline
\end{tabular}

(a) Contractor's overhead and profit: $10 \%$ on material and equipment, $42.6 \%$ on labor.

at 72,000 Btuh with $40^{\circ} \mathrm{F}$ inlet water temperature. Integral condenser and blower, air filter and water flow control valves are provided. No backup resistance heating is provided. Eighteen gpm of $40^{\circ} \mathrm{F}$ water is required at the design heating load. Air distribution for Zone $I$ is provided by a reducing trunk air distribution system with a main supply trunk extending east-west along the ceiling of the woodshop with branches to the office, machine shop and boiler room. Vertical face supply registers are used. Two return grills are provided on a short return trunk with one grill located in the woodshop and the second in the machine shop. A transfer duct to the machine shop is used for boiler room return, and a transfer grill provides return from the office. The distribution system is based on 2500 CFM air flow at 0.15 inch water gage external static pressure. (a) All ductwork is exposed and uninsulated and is of rectangular galvanized steel construction. Fire dampers are

(a) Blowers having greater capacity are available which might permit use of more compact ductwork. 
provided at the boiler room penetrations. Zone I blower and compressor control is provided by a wall-mounted thermostat.

Two horizontal single package heat pumps, mounted in the overhead of the mezzanine, are used as heat sources for Zone II (Figure C.6). These are heatonly units rated at 72,000 Btuh each with $40^{\circ} \mathrm{F}$ inlet water temperature. Condenser and blower, air filters and water flow control valves are integral to the units. No backup resistance heating is provided. Eighteen gpm of $40^{\circ} \mathrm{F}$ water is required by each unit at design conditions for a total of $36 \mathrm{gpm}$ for Zone II. The two Zone II units are installed in tandem, providing 5000 CFM airflow at 0.15 inch water gage external static pressure. Staged control is provided such that the second unit is operated only at heat loads exceeding the capacity of the first unit. Electrical lockout of the second unit is provided by an outdoor thermostat set at the balance point temperature. Room temperature control is provided by a wall-mounted thermostat.

Zone II air distribution is provided by a reducing trunk air distribution system having a main supply trunk extending east-west along the ceiling of the garage and mezzanine. Branches extend to the rear storage area and diver supply room. Vertical-face supply registers are used throughout. Return grills are located on either side of the garage near floor level with supplementary returns in the front storage area, rear storage area and diver supply room. All ductwork is exposed and uninsulated and is of rectangular galvanized steel construction. Backflow prevention dampers are provided at each heat pump discharge.

Sea water is provided to the Zone I and Zone II heatpumps by a common sea water system supplied by a pierside submersible pump. Intermittent chlorination is used to retard fouling by marine organisms. Automatic pressure control is provided by an air-loaded hydrotank (Sẹ Figure C.7).

A 5.7 horsepower submersible pump capable of delivering $60 \mathrm{gpm}$ at 200 foot head is suspended in an eight inch steel casing mounted inboard of the pier face. The casing is provided with several intake slots located at depths of 20-25 feet below low water level. Pump discharge is directed through a basket strainer then through an insulated 2 inch supply line running below the pier deck to the seawall and thence underground along the north side of the warehouse to the hydrotank located under the stairs. The chlorinator discharge is 
routed back along the supply line to the vicinity of the casing head where it taps the main supply. Intermittent chlorination is provided by automatic control. The sea water supply header is routed back along the north wall of the warehouse at ceiling level with branches to the Zone I and Zone II units. Each heat pump is provided with an inlet throttle valve for system balancing and a gate valve is provided on the discharge to allow unit isolation for maintenance. Boiler drains on the inlet and discharge piping of each unit allow heat exchanger backflushing. Supply and discharge temperature and pressure instrumentation are also provided. Sea water returns to the channel by a 2 inch header discharging at the seawall. Sea water piping and fittings are of PVC for corrosion resistance. The submersible pump is of iron construction with a stainless steel shaft and is rated for salt water use. Fittings not available in PVC are of bronze. All piping is insulated.

\section{Cost Estimate}

The cost estimate for this design, based on retrofit construction, is summarized in Table 5.4. Included are regional cost adjustments, contractor's overhead and profit, and a contingency allowance of $10 \%$.

\subsubsection{Snettisham Salmon Hatchery}

Heating System Design

The conceptual heating system for the Snettisham Salmon Hatchery uses three water source heat pumps supplied with fresh water from the Snettisham hydroelectric facility tailrace. Two independent warm air distribution systems are established. Zone II includes that portion of the hatchery building having a $45^{\circ} \mathrm{F}$ interior design temperature, and utilizes two water source heat pumps of 85,000 Btuh nominal heating capacity, installed in tandam and controlled for staged compressor operation. The other zone includes that portion of the building having a $70^{\circ} \mathrm{F}$ interior design temperature, and utilizes a single heat pump having 72,000 Btuh nominal heating capacity. The salmon hatchery heating system is designed as a new construction system and insofar as appropriate to a system utilizing water source heat pumps, duplicates the control, ventilation and safety features of the hatchery heating and ventilation system as presently designed. 
TABLE 5.4. Cost Estimate, Subport Warehouse (1980\$)

\begin{tabular}{|c|c|c|c|c|}
\hline Item & Labor & $\begin{array}{l}\text { Material } \\
\text { and } \\
\text { Equipment }\end{array}$ & Subcontracts & Total \\
\hline Ductwork and Accessories & 11,370 & 3330 & 80 & \\
\hline Water Supply and Return & 8220 & 8250 & 1390 & \\
\hline Heat Pump & 1470 & 19,810 & -- & \\
\hline Electrical and Control & 2530 & 1470 & -- & \\
\hline Test and Balance & - & - & $\underline{1380}$ & \\
\hline Subtotal & 23,590 & 32,860 & 2850 & \\
\hline Contractors 0\&p (a) & $\underline{10,050}$ & 3290 & - & \\
\hline Subtotal, inc $0 \& P$ & 33,640 & 36,150 & 2850 & 72,640 \\
\hline Contingency, $10 \%$ & & & & 7260 \\
\hline Total & & & & 79,900 \\
\hline
\end{tabular}

(a) Contractor's overhead and profit: $10 \%$ on material and equipment, $42.6 \%$ on labor.

Zone $I$ includes the portion of the structure having a $70^{\circ} \mathrm{F}$ interior design temperature. This area includes the office, shop, mechanical room \#1, laboratory and restrooms. An upright single package heat pump rated at 72,000 Btuh heating capacity with $40^{\circ} \mathrm{F}$ inlet water temperature is used as the heat source for Zone $I$. This unit is located against the south wall of mechanical room \#1 (Figure C.9). (a) This unit includes an integral blower and condenser, air filter and water flow control valves.

Air distribution for Zone $I$ is provided by a reducing trunk air distribution system located in the overhead of the hallway (Figure C.9). A ceiling diffuser is provided in the hallway and branches extend to the shop, office, men's and women's restrooms, and the laboratory. Each branch terminates with

(a) To accomodate the Zone I heat pump it would be necessary to relocate the domestic water system hydrotank to the north wall of mechanical room \#1, adjacent to the domestic water pump. No other major relocations would be required. 
a high-sidewall supply register except for the laboratory, which is equipped with a ceiling diffuser. Two returns are provided, one from the shop and a second from the hall.

Fresh air is introduced into the system by ductwork leading from the exterior fresh air intake on the north wall of mechanical room \#1. Thermostatic control of outside and return air mixing dampers is provided. Exhaust from Zone $I$ is by a wall exhaust fan located in the shop and ceiling exhausts in the restrooms, as provided in the current hatchery plan. Fire dampers are installed at all penetrations to mechanical room \#1. The distribution system is based on 2500 CFM air flow at 0.5 inch water gage external static pressure. All ductwork is of rectangular galvanized steel constructon. Return and outside air ducts are provided with sound attenuating lining. Safety and ventilation controls similar to those of the existing hatchery heating and ventilation system are provided. Room temperature control is by wall-mounted thermostat.

Zone II includes the portion of the building having a $45^{\circ} \mathrm{F}$ interior design temperature. This area includes the egg handling room, incubation room, storage room and mechanical room \#2. Two upright single package heat pumps installed in mechanical room \#1 are used as the heat sources for this zone. These units are rated at 85,000 Btuh heating capacity with $40^{\circ} \mathrm{F}$ inlet water temperature. These units are located side by side out from the west wall of mechanical room \#1 (Figure C.9). Each unit includes an integral blower and condenser and water flow control valves. Separate filters located in the common return duct are used. Heated air for Zone II is taken through backflow prevention dampers at the discharge of each unit then distributed through a reducing trunk system. Two main branches are provided (Figure C.9); one along the north wall of the incubation room and the second along the south wall of the incubation room and continuing through mechanical room \#2 to serve the egg handling room. Vertical-face supply registers are provided along both exterior walls of the incubation room, on the exterior wall of the mechanical room \#1, and along the east wall of the egg handling room. The return is located at the northeast corner of the incubation room. This arrangement is similar to the existing ventilation system. Return air passes to a mixing chamber, located in mechanical room \#1, where outside air is admitted from the fresh 
air intake on the north wall of mechanical room \#1. Thermostatic control of outside and return air mixing dampers is provided. Exhaust from Zone II is provided by the existing exhaust fan EF-1. This fan exhausts from the storage room which is provided with transfer ducting from the incubation room. Fire dampers are located at ductwork penetrations to the storage room. The distribution system is based on 6000 CFM air flow at 0.5 inch water gage external static pressure. All ductwork is of rectangular galvanized steel construction and return and outside air ducts are provided with sound attenuation lining. Safety and ventilation controls similar to those of the existing heating and ventilation system are used. Staged control is provided such that the second unit is normally operated only at heat loads exceeding the capacity of the first unit. Electrical lockout of the second unit is provided by an outdoor thermostat set at the balance point temperature. Room temperature control by wall-mounted thermostat.

Water requirements at design heating capacity are $18 \mathrm{gpm}$ for the Zone I unit and $21.6 \mathrm{gpm}$ for each of the Zone II units, at $40^{\circ} \mathrm{F}$ inlet water temperatures. Water is supplied from the domestic water supply system, modified to provide increased delivery capacity. Water tapped upstream of the chlorinator (Figure C.8) is delivered to the heat pumps by a 2 inch header. The supply header is equipped with backflow prevention and isolation valves, a Y-type strainer, and pressure and temperature instruments. One inch supply and return branches serve each unit. Each supply branch is provided with a globe valve for system balancing. Gate valves are provided on the return branches for unit isolation. Boiler drain valves are installed on the supply and return branches for heat exchanger backflushing. Supply and return pressure instrumentation and discharge temperature instrumentation are also supplied. A 2 inch combined return header discharges to the building drain system. All piping is of copper with fittings of bronze, and is insulated throughout. The domestic water supply system would retain its current configuration but would be increased in capacity from 20 to $80 \mathrm{gpm}$ at $60 \mathrm{psig.}$

(a) System capacity requirements could be reduced by use of a reverse acting pressure switch on the domestic water system hydrotank. This switch, which would interrupt compressor operation during momentary domestic demand peaks, would reduce system capacity requirements to $60 \mathrm{gpm}$ and would reduce pump cycling. 
A three horsepower supply pump would be required and pipe sizes would be increased to 4 inches for the headbox downcomer, $21 / 2$ inches for the pump suction and 2 inches for the pump discharge to the hydrotank.

\section{Cost Estimates}

The cost estimate for the Snettisham Salmon Hatchery heating and ventilation system, based on new construction, is summarized in Table 5.5. Included are regional cost adjustments, contractor's overhead and profit and a contingency allowance of $7.5 \%$.

TABLE 5.5. Cost Estimate, Snettisham Sạmon Hatchery (1980\$)

\begin{tabular}{|c|c|c|c|c|}
\hline Item & Labor & $\begin{array}{c}\text { Material } \\
\text { and } \\
\text { Equipment }\end{array}$ & Subcontracts & Total \\
\hline Ductwork and Accessories & 12,570 & 5910 & -- & \\
\hline Water Supply and Return & 1710 & 1570 & -- & \\
\hline Heat Pump & 1680 & 21,430 & -- & \\
\hline Electrical and Control & 540 & 130 & 7240 & \\
\hline Test and Balance & -- & - & $\underline{1610}$ & \\
\hline Subtota 1 & 16,500 & 29,040 & 8850 & \\
\hline Contractors 0\&P(a) & 7030 & 2900 & $=$ & \\
\hline Subtotal, inc $0 \& P$ & 23,530 & 31,940 & 8850 & 64,320 \\
\hline Contingency, $7.5 \%$ & & & & 4830 \\
\hline Tota 1 & & & & 69,150 \\
\hline
\end{tabular}

(a) Contractor's overhead and profit: $10 \%$ on material and equipment, $42.6 \%$ on labor. 


\section{REFERENCES - CHAPTER 5.0}

Air Conditioning Contractors of America. 1975. Load Calculation for Residential Winter and Summer Air Conditioning. Washington, D.C.

McConaghy, J. A. 1969. Hydrologic Data of the Juneau Borough, Alaska. Prepared by the United States Geological Survey in cooperation with The Greater Juneau Borough. 


\subsection{EVALUATION OF ALTERNATIVE DESIGNS}

\subsection{INTRODUCTION}

In this chapter the WSHP-based heating system designs presented in Chapter 5 are compared with alternative methods of heating typical for that type of structure. For the new residence case, WSHP heating is compared to electrical resistance baseboard (both direct and fluid filled), oil-hydronic, and air to air heat pump heating. For the filter building and the warehouse WSHP heating is compared with the existing heating system; forced air oil furnace heating in the case of the filter building and oil-hydronic heating in the case of the warehouse. In the Snettisham salmon hatchery case the WSHP design is compared with the electrical resistance heating system presently designed for the building.

The alternative heating systems are compared based upon three considerations: 1) life cycle costs, 2) technical viability, and 3) effect on fossil and electrical energy use. The life cycle cost comparison looks at the total cost of heating the structures with the alternative methods discussed above over the 10-year period from 1981 through 1990. The purpose of the technical evaluation is to compare the system from the standpoint of ease of installation, operation, and maintenance. Because of the high economic and strategic cost of fuel oil in the Juneau area (as well as in the U.S., as a whole) and the availability of electric power in the Juneau area, the impact of the WSHP heating systems on the consumption of these energy sources is also evaluated.

\subsection{LIFE CYCLE COST COMPARISONS}

As pointed out above, this life cycle cost evaluation looks at the total cost of heating the structures over the 10-year period from 1981 to 1990. Three cost components are evaluated for each system: energy costs, operating and maintenance (O\&M) costs, and capital investment costs. This comparison takes into account the effects of inflation on the energy costs and the 0\&M costs, and the costs of financing the initial purchase of the system. 
A key parameter value that must be established and used throughout the life cycle cost comparisons is the rate of inflation. As discussed in Chapter 1 , the increase in energy prices can be keyed to the rate of inflation. In addition, the discount rate at which the initial investment is financed and the rate of increase of the 0\&M costs can be keyed to the rate of inflation. In this evaluation the rate of inflation over the 1981-1990 time period is assumed to be $8 \%$ per year. While this is considerably lower than the current rate of inflation (approximately 15-18\% per year) it is a relatively high value for the U.S. for a 10-year period.

Using the rate of inflation as a basis, the various discount and escalation rates to be used in the cost analys is were selected. They are presented in Table 6.1 below.

TABLE 6.1. Discount and Escalation Rates Assuming an $8 \%$ Rate of General Inflation

\author{
$\underline{q / Y r}$ \\ Fuel 0il Price Escalation \\ 11 \\ Electricity Price Escalation \\ 4 \\ O\&M Cost Escalation \\ 8 \\ Financing Discount Rate

The methods used to compute the annual costs are similar for all the alternative structures and heating methods analyzed. The general methods and data used in the cost analyses are described in this section while the data and assumptions specific to each alternative structure are described in Sections 6.2.1 through 6.2.4.

The annual energy costs are computed using the price of energy (either fuel oil or electricity) and the annual energy consumption. The prices of fuel $0 i 1$ and electricity in the Juneau area assuming an $8 \%$ rate of inflation from 1981 to 1990 were presented in Figures 1.1 and 1.2 , respectively. 
The annual energy consumption is computed using the heating efficiency of particular heating methods and the annual heating requirements of the particu1 ar structure. The heating efficiencies of the various heating methods are presented along with the descriptions of the specific cases in the following four sections. The annual heating requirement is determined using the outdoor temperature distribution for a year (which gives the hours per year that the outside temperature is within specific temperature ranges) and the heat load at that temperature. Since the heat load for a structure is assumed to be a linear function of the outside temperature, the heat load at any specific temperature is proportional to the heat load at design conditions. The design heat loads for the four structures are presented in Table 5.1.

By multiplying the heat load $(B t u / h r)$ of a structure at a specific temperature by the number of hours that the outdoor temperature is at that temperature and then adding the heat loads (Btu) at the various temperatures together, the total annual heating requirement is computed. The annual heating requirement calculations for the cases evaluated in this report are presented in Appendix D, Tables D.1 through D.5. They are summarized in Table 6.2 below.

TABLE 6.2. Annual Heating Requirement for Structures Evaluated

Case

1. New Residential Construction Mendenhall Valley

2. Filter Building Auke Bay

3. Warehouse Subport - Juneau

4. Fish Hatchery Snettisham
Annual Heating Requirement (1000 Btu) (kWh)
$125,508 \quad 36,773$

$471,216 \quad 138,065$

$699,779 \quad 205,033$ 
The annual 0\&M costs are computed based upon the number of hours that a repairman would be required to maintain the heating system. No material costs are included in the 0\&M category for any of the heating systems. There is little information available on the maintenance materials cost for heating systems. It was assumed that either no materials would be required beyond the initial installation or that their costs would be covered by warranty.

The equivalent annual investment costs were computed assuming a financing discount rate of $11 \%$ and, in general, a financing period of 25 years. The compressor portion of both the ASHP and the WSHP heating systems were separately evaluated using a 10-year financing period to reflect their anticipated shorter lifetime.

The annual energy costs, 0\&M costs, and capital investment costs are added together to give the total annual heating costs. To facilitate the comparison of the life cycle costs of the alternative heating methods a "levelized" cost is computed. The levelized cost is computed using the present worth of the annual costs over the time period of interest. In equation form:

$$
\text { Levelized Cost }=\text { PWAC * CRF }
$$

where

$$
\begin{aligned}
\text { PWAC }= & \text { present worth of the annual costs } \\
\mathrm{CRF}= & \text { capital recovery factor - the factor by which a present sum is } \\
& \text { multiplied to find a future series that is equivalent to the } \\
& \text { present sum at a specific discount rate and time period. A } \\
& \text { capital recovery factor for } 10 \text { years at a } 8 \% \text { discount rate is } \\
& \text { used in this study }(0.14903) .
\end{aligned}
$$

In turn

$$
P W A C=\sum_{i=1}^{n} A C_{i} * \frac{1}{(1+r)^{i}}
$$


where

$$
\begin{aligned}
A C_{i} & =\text { annual costs in year } i \\
r & =\text { discount rate }(8 \%) \\
n & =\text { time period }(10 \text { years }) \\
i & =\text { year }(1,2,3 \ldots n)
\end{aligned}
$$

In the following four sections the life cycle heating costs for the alternative heating systems are developed for the four cases considered in this report.

\subsubsection{New Residential Construction in the Mendenhall Valley}

General details regarding the computation of the annual fuel cost was presented in Section 6.2. The heating efficiencies for the five alternative heating systems evaluated for this case are presented in Table 6.3 below.

TABLE 6.3. Season System Efficiencies/COPs for Residential Heating Systems

\begin{tabular}{lc}
\multicolumn{1}{c}{ System } & $\begin{array}{c}\text { Efficiency } \\
\text { or COP }\end{array}$ \\
$\begin{array}{l}\text { Direct and fluid- } \\
\text { filled electrical } \\
\text { resistance baseboard }\end{array}$ & $100 \%$ \\
0il-Hydronic & $55 \%$ \\
ASHP & 1.92 \\
WSHP & 2.25
\end{tabular}

Electrical resistance heating is assumed to be $100 \%$ efficient. Typical residential oil-hydronic heating systems have efficiencies in the 50 to $60 \%$ range. An average value of $55 \%$ is used in this case. Fuel oil is assumed to have a heating value of $138,690 \mathrm{Btu} / \mathrm{gal}$.

An ASHP seasonal system COP of 1.92 was assumed. This value was obtained from a previous analys is of ASHP heating costs done for a residence in the Juneau area with the same outdoor temperature distribution as was assumed for the Mendenhall Valley (CH2M 1980, Appendix Table 6). 
A WSHP seasonal system COP of 2.25 was assumed. Manufacturers literature gives WSHP COPS for $40^{\circ} \mathrm{F}$ in let water of from about 2.75 to 4.0 (not including the power required for pumping the water). A relatively conservative value of 3.0, exluding the power required for water pumping was assumed for this evaluation. When the power required for pumping the water was included, a seasonal COP of 2.25 was obtained. As indicated above, this is a relatively conservative estimate. Some manufacturers have options available to specifically adopt their units to low water temperature applications. Such units may give higher COPs.

The 0\&M labor requirements for the five alternative heating methods for the 10-year period 1981 to 1990 are shown in Table 6.4. Both types of electrical resistance heating are relatively maintenance free. Two hours of maintenance time is assumed after 10 years. 0il-hydronic heating system are assumed to require an annual maintenance check requiring 1.5 hours of time. In years 1985 and 1990 it is assumed that an additional 1.5 hours are required for miscellaneous repairs. There is little data available on the long-term maintenance requirements for ASHPS and even less for WSHPs. It is assumed that TABLE 6.4. O\&M Labor Requirements for Residential Heating Systems,
1981-1990 (man-hrs)

Electrical

Resistance

(Both Types) 0il-Hydronic ASHP WSHP

1981

1982

1983

1984

1985

1986

1987

1988

1989

1990

$\begin{array}{ll}-- & 1.5 \\ -- & 1.5 \\ -- & 1.5 \\ -- & 1.5 \\ -- & 3.0 \\ -- & 1.5 \\ -- & 1.5 \\ -- & 1.5 \\ -- & 1.5 \\ 2.0 & 3.0\end{array}$

1.5

1.5

1.5

1.5

3.0

1.5

1.5

1.5

1.5

3.0

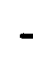

2.0

2.0

$-$

$-$

4.0

4.0

$-$

2.0

2.0

--

4.0

4.0

4.0 
both types of heat pump will require a system recharge every 2 or 3 years requiring 2 hours of time with 2 hours of additional maintenance required in 1985 and 1990.

The costs of purchasing and installing the WSHP heating system for the residence were discussed and presented in Section 5.4.1. These costs are summarized and the equivalent annual investment costs are presented in Table 6.5 .

TABLE 6.5. WSHP Heating System Purchase and Installation Costs and Equivalent Annual Investment Costs - Mendenhall Valley Residence

\begin{tabular}{|c|c|c|c|}
\hline Item & $\begin{array}{c}\text { Total } \\
\text { Cost } \\
(\$) \\
\end{array}$ & $\begin{array}{c}\text { Useful } \\
\text { Life } \\
\text { (yrs) }\end{array}$ & $\begin{array}{c}\text { Annual } \\
\text { Cost } \\
\text { (\$/yrs) }\end{array}$ \\
\hline Total System Less Compressor & 13,400 & 25 & 1,592 \\
\hline Compressor & 1,600 & 10 & 272 \\
\hline Total & 15,500 & -- & 1,864 \\
\hline
\end{tabular}

The purchase prices and annual investment costs for the comparable heating systems are presented in Table 6.6.

The life-cycle cost calculations for the alternative heating systems evaluated for this case are presented in Appendix D; Tables D.6 through D.10. The results of those calculations (the levelized annual costs) for the five alternative heating systems are summarized in Table 6.7. As shown in Table 6.7, WSHP heating costs are comparable to electrical resistance heating costs. ASHPs offer the lowest heating costs while oil-hydronic heating is the most costly. The reasons for these results are discussed in the following paragraphs.

WSHPs have the lowest energy cost of any of the alternatives considered. They use electricity which has a lower energy cost than fuel $0 i 1$ and they use it more efficiently to heat than either electrical resistance or ASHPs.

WSHPS O\&M costs are expected to be moderate compared to other heating methods. Electrical resistance heating features very low 0\&M costs while oilhydronic has the highest 0\&M costs. It is important to keep in mind, however, that in the event of a major component failure both types of heat pumps would 
TABLE 6.6. Purchase Price and Annual Equivalent Investment cost for Alternative Heating Systems - Mendenhall Valley Residence

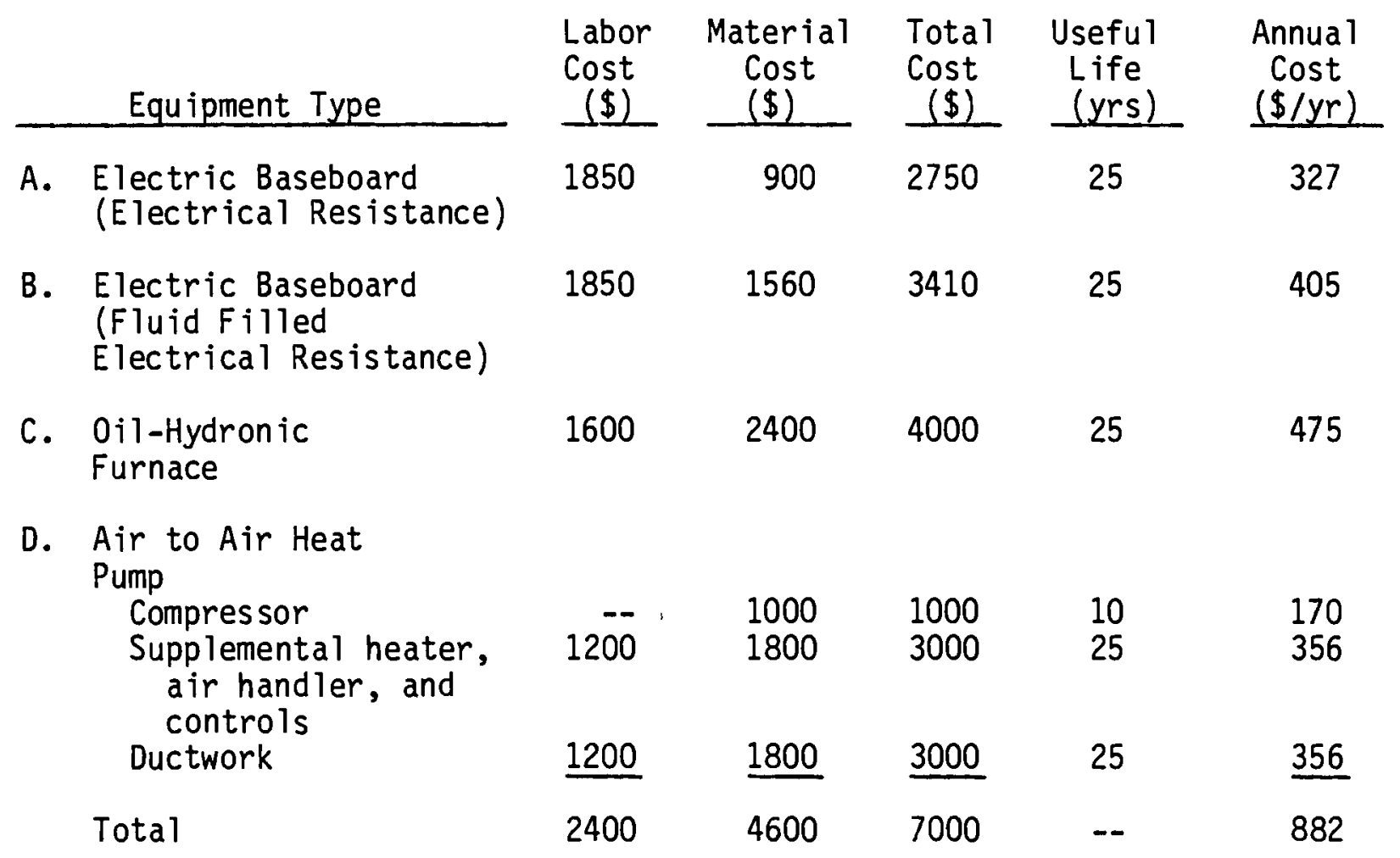

Source: (CH2M 1980, p. 10) and discussion with Mel Dehart (Jack's Plumbing and Heating) and Steve Winters (Winters Electric), April 7, 8, and 9th.

TABLE 6.7. Levelized Costs for Alternative Heating Methods Mendenhall Valley Residence

$\begin{array}{lr}\text { Direct Electrical Resistance } & \$ 2921 \\ \text { Fluid-Filled Electrical Resistance } & 2999 \\ \text { Oil-Hydronic } & 4495 \\ \text { Air Source Heat Pump } & 2283 \\ \text { Water Source Heat Pump } & 3092\end{array}$

probably be the most expensive to fix. Such an event would probably give them the highest 0\&M costs. It is important that the initial design and installation of heat pump heating systems be done properly to reduce the possibility of a later major component failure. 
WSHPs have the highest purchase and installation cost and as a result have the highest annual investment cost. For this case the purchase and installation cost for the WSHP heating system is about twice as expensive as the ASHP heating system. There are three primary reasons for this. Firstly, WSHPs require larger air ducts because they have no electrical resistance supplemental heating and, thus, must circulate more lower temperature air at design heating conditions than ASHPS. Secondly, WSHPs require a relatively expensive water supply and disposal system. Thirdly, WSHPs are a relatively new heating system and are not manufactured in the quantities that ASHPs are. This typically results in higher manufacturing costs.

Electrical resistance systems have the lowest purchase and installation costs. 0il-hydronic systems also have a relatively low purchase and installation cost compared to heat pump systems

The levelized costs shown in Table 6.7 will vary, of course, if different assumptions are made that would change the energy costs, the 0\&M costs, or the annual investment costs. While it would be interesting to see how the costs would vary under alternate assumptions, it is unlikely that the rank ordering of the heating costs would change greatly. While WSHP costs could possibly be lower than either type of electrical resistance heating system under some conditions, it is unlikely that WSHP heating costs could be lower than ASHP heating costs or higher than heating costs for an oil-hydronic system.

\subsubsection{Filter Building at the Auke Bay Laboratory}

In this case the heating costs for the existing forced air oil furnace are compared with the costs of heating the building with a WSHP. The costs are compared in two ways. In one case it is assumed that the decision to be made is whether to replace the existing heating system with a WSHP system. In this case the costs of installing a WSHP heating system are compared with the future 0\&M and fue 1 costs of the existing system. It is assumed that the existing heating system is paid off and has no salvage value.

In the other case it is assumed that the decision is to be made for a new building that does not have an existing heating system. For this case total costs are compared as with the residential case. 
A heating efficiency of $55 \%$ was assumed for the forced air furnace heating system and a COP of 2.40 was used for the WSHP system. This COP assumes a COP of 3.0 excluding water pump energy requirements. When the water pumping energy is included, a seasonal COP of 2.40 is obtained.

The 0\&M labor requirements for the filter building were assumed to be the same as for the residential case for the respective heating systems.

The costs of purchasing and installing a WSHP heating system for this case were discussed and presented in Section 5.4.2. These costs are summarized and the equivalent annual investment costs are presented in Table 6.8. The purchase prices and annual investment costs for a forced air oil furnace are also presented in Table 6.8 .

TABLE 6.8. Heating System Purchase and Installation Costs and Equivalent Annual Investment Costs - Filter Building

\begin{tabular}{ccccc}
$\begin{array}{c}\text { Labor } \\
\text { Cost }\end{array}$ & $\begin{array}{c}\text { Material } \\
\text { Cost }\end{array}$ & $\begin{array}{c}\text { Total } \\
\text { Cost }\end{array}$ & $\begin{array}{c}\text { Useful } \\
\text { Life }\end{array}$ & $\begin{array}{c}\text { Annual } \\
\text { Cost } \\
(\$)\end{array}$ \\
\hline
\end{tabular}

A. WSHP System

Total System Less

Compressor

Compressor

Total

$\begin{array}{lllll}-- & -- & 16,006 & 25 & 1,902 \\ = & - & 1,984 & 10 & 338 \\ -- & -- & 17,990 & -- & 2,240\end{array}$

B. Forced Ajr Furnace

Furnace

$(140,000 \mathrm{Btu} / \mathrm{hr}$ rating)

$\begin{array}{rrrrr}-- & 900 & 900 & 25 & 107 \\ 1,400 & 400 & 1,800 & 25 & 214\end{array}$

Ducting

Misce 11 aneous

(oil tank fue 1

lines, controls)

$\frac{400}{1,800} \quad \frac{500}{1,800} \quad \frac{900}{3,600} \quad \frac{25}{25} \quad \frac{107}{428}$

Total

(a) Source: Discussions with Juneau area heating contractors, April-May 1980. 
The life-cycle cost calculations for the oil furnace and WSHP heating system are presented in Appendix D; Tables $D .11$ and $D .12$, respectively. The levelized annual costs for these two systems are presented in Table 6.9.

\section{TABLE 6.9. Levelized Annual Costs for Alternative Heating Methods - Filter Building}

\begin{tabular}{|c|c|c|}
\hline 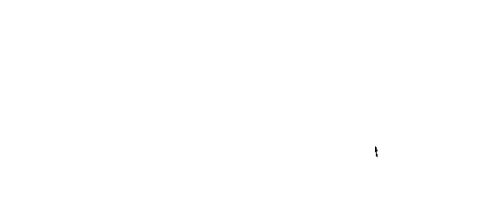 & $\begin{array}{c}\text { Excluding } 0 i 1 \\
\text { Furnace } \\
\text { Replacement } \\
\text { Costs }(\$) \\
\end{array}$ & $\begin{array}{c}\text { Including } 0 \text { il } \\
\text { Furnace } \\
\text { Replacement } \\
\text { Costs }(\$) \\
\end{array}$ \\
\hline rrced Air $0 i 1$ Furnace & 2780 & 3208 \\
\hline
\end{tabular}

As shown in Table 6.9 the heating costs of the WSHP heating system are very similar to the heating costs for the forced air oil furnace heating systems.

As with the Mendenhall Valley residence case the WSHP heating system has much lower energy costs than the oil-based heating system. The lower energy costs of the WSHP system are offset, however, by the much higher purchase and installation costs of the WSHP system.

Excluding the oil furnace replacement cost results in the existing oilbased heating system having a lower life-cycle cost than the replacement WSHP heating system. Based on this analysis it would be less costly to retain the present heating system than to replace it with a WSHP heating system.

It is interesting to compare the heating costs for the WSHP heating systems and the oil-based systems for the Mendenhall Valley residence and the filter building. In the case of the residence, the heating costs for the oil-based system were considerably higher than the costs for the WSHP system (\$4495 compared to $\$ 3092$ ). In the filter building, on the other hand, the costs for the two systems are roughly comparable ( $\$ 3208$ for oil heating and $\$ 3254$ for the WSHP system).

The basis for this difference in relative heating costs partially lies in the relative annual utilization of the heating system in the residence compared 
to the utilization of the heating system in the filter building. WSHPs have high initial purchase and installation costs but low energy costs. They are more economically viable in applications having high utilization. 0il furnace heating systems have relatively low purchase and installation costs but relatively high energy costs. They will tend to be more economical in applications having lower utilization.

The residence has a design heat load of $49,000 \mathrm{Btu} / \mathrm{hr}$ with an annual heating requirement of $183,917,000$ Btu while the filter building with a higher design heat load of $57,000 \mathrm{Btu} / \mathrm{hr}$ has a lower annual heating requirement of $125,508,000 \mathrm{Btu}$. The reason for the relatively low annual heating requirement, in the case of the filter building, is that the outdoor design temperature for the filter building is $-5^{\circ} \mathrm{F}$ compared to $-15^{\circ} \mathrm{F}$ for the residence. It is assumed that the overall temperature distribution is $10^{\circ} \mathrm{F}$ higher at Auke Bay than in the Mendenhall Valley. This difference causes the filter building to have a lower annual heating requirement relative to the design heat load than the residence.

\subsubsection{Warehouse on the Juneau Waterfront}

In this case the heating costs for the oil hydronic heating system in the existing NMFS warehouse are compared with the costs of heating the building with a WSHP heating system. As explained in Section 5.4.3, three separate WSHPs are used in the design. As with the filter building case, the costs are compared in two ways: 1) assuming that a decision is being made whether to replace the existing heating system and 2) assuming a new building without an existing heating system.

A heating system efficiency of $70 \%$ is assumed for the existing heating system. This is higher than the efficiency assumed for the residence and filter building (55\%). The higher efficiency is assumed because of the larger size of the oil boiler which should allow for more efficient operation. As with the previous cases a WSHP COP of 3.0 excluding water pumping energy is assumed. With the energy required for pumping the supply water, a system seasonal COP of about 2.3 is obtained.

The 0\&M labor requirements for the two cases are shown in Table 6.10. 
TABLE 6.10. O\&M Labor Requirements for the Warehouse

Heating Systems, 1981-1990 (man-hrs)

\begin{tabular}{lcrr} 
& Oil-Hydronic & WSHP \\
\cline { 2 - 2 } 1981 & 3.0 & 5.0 \\
1982 & 3.0 & 11.0 \\
1983 & 3.0 & 5.0 \\
1984 & 3.0 & 5.0 \\
1985 & 6.0 & 17.0 \\
1986 & 3.0 & 5.0 \\
1987 & 3.0 & 11.0 \\
1988 & 3.0 & 5.0 \\
1989 & 3.0 & 5.0 \\
1990 & 6.0 & 17.0
\end{tabular}

The O\&M labor requirements are extrapolated from the O\&M requirements for the residential case with additional time included in the WSHP system for maintenance of the chlorinator and sea water supply system. The 0\&M requirements for the oil hydronic system were increased by a factor of 2 each year over the residential case. For the WSHP system it was assumed that annual routine maintenance on the water supply system and the chlorinator system would require 5 hours. Maintenance on the WSHPs was assumed to be 2 hours per unit (a total of 6) during 1982 and 1987 and 4 hours per unit (a total of 12) during 1985 and 1990.

Sodium hypochlorite will be used to provide chlorine for the chlorinator system. As discussed in Chapter 4 sodium hypochlorite costs about $\$ 17.45$ / 6 gallons. Assuming a maximum water flow rate of about $54 \mathrm{gpm}$ and that the system operates 9 months out of the year, sodium hypochlorite would cost about $\$ 165 /$ year.

The costs of purchasing and installing the WSHP heating system for the case were presented in Section 5.4.3. These costs are summarized and the equivalent annual investment costs are presented in Table 6.11. The cost and annual investment costs for an $0 i 1$ hydronic heating system are also presented in Table 6.11. 
TABLE 6.11. Heating System Purchase and Installation Costs and Equivalent Annual Investment Costs - Warehouse

Equipment Type

A. WSHP System

Total System Less

Compressors and

Water Pump

Compressors and

Water Pump

Tota 1

\section{Total Useful Annual}

Cost Life Cost

(\$) (yrs) (\$/yr)

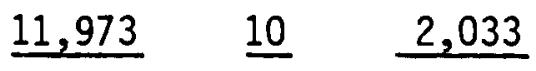

$80,000 \quad--\quad 10,117$

B. 0 il Hydrgnic

Total System $\quad 30,000 \quad 25 \quad 3,565$

(a) Battelle estimate based on discussions with Juneau area heating contractors, April-May 1980.

The life cycle cost calculations for the oil furnace and WSHP heating system are presented in Appendix $D$; Tables 0.13 and 0.14 , respectively. The results of these computations are shown in Table 6.12 .

TABLE 6.12. Levelized Annual Costs for Alternate Heating Methods - Warehouse

$\begin{array}{cc}\begin{array}{c}\text { Excluding } 0 i 1 \\ \begin{array}{c}\text { Furnace } \\ \text { Replacement } \\ \text { Costs }(\$)\end{array}\end{array} & \begin{array}{c}\text { Including } 0 i 1 \\ \text { Furnace } \\ \text { Replacement } \\ \text { Costs }(\$)\end{array} \\ 7,590 & 11,155 \\ 13,749\end{array}$


As shown in Table 6.12 the levelized annual heating costs of the WSHP system are higher than the heating costs for the oil hydronic heating system $(\$ 13,749$ compared to $\$ 11,155)$. While the WSHP system has lower energy costs, the higher annual investment costs more than offset this advantage.

When the furnace replacement costs are not included the cost advantage of the existing oil heating system is even greater $(\$ 7,590$ compared to $\$ 13,584)$. It would not be justified from a cost standpoint to replace the existing heating system with a WSHP system.

\subsubsection{Salmon Hatchery Near Snettisham Hydroelectric Project}

This case compares the cost of heating a salmon hatchery with WSHPs to the cost of heating the building using electrical resistance heaters. The hatchery is presently under construction near the Snettisham hydroelectric project. The heating efficiency of the electrical resistance system is assumed to be $100 \%$. A seasonal system COP for the WSHP system of 2.5 is used. As in the previous cases a COP of 3.0 is assumed excluding the water pumping energy required. When the water pumping energy is included the assumed system COP of 2.5 is obtained.

The 0\&M labor requirements for the two heating systems are shown in Table 6.13. The electrical resistance heating system can be expected to be

TABLE 6.13. O\&M Labor Requirements for the Salmon Hatchery Heating Systems, 1981-1990 (man-hrs)

\section{Electrical}

Resistance

WSHP

1981

1982

1983

1984

1985

1986

1987

1988

1989

1990

$\begin{array}{lc}-- & -- \\ -- & 6.0 \\ -- & -- \\ -- & -- \\ 4.0 & 12.0 \\ -- & -- \\ -- & 6.0 \\ -- & -- \\ -- & -- \\ 4.0 & 12.0\end{array}$


relatively maintenance free. The 4 hours included in 1985 and 1990 would be for routine cleaning and for replacement of any possible defective or broken units. The WSHP system maintenance requirements are extrapolated from the residential case. Maintenance on the units was assumed to be 2.0 hours per unit during 1982 and 1987 and 4 hours per unit in 1985 and 1990.

The costs of purchasing and installing the WSHP heating system were presented in Section 5.4.4. These costs are sumarized and the equivalent annual investment costs are presented in Table 6.14. The costs for the planned electrical resistance heating system are also shown in Table 6.14.

The cost calculations for this case are presented in Tables 0.15 and D.16. The results are shown in Table 6.15. As shown in Table 6.15 the levelized annual heating costs for the electrical resistance heating system are less than the heating costs for the WSHP system. The difference (about $8 \%$ ) is relatively small, however.

TABLE 6.14. Heating System Purchase and Installation Costs and Equivalent Annual Investment Costs - Salmon Hatchery

\begin{tabular}{cccc} 
& Total & Useful & Annual \\
& Cost & Life & Cost \\
Equipment Type & $(\$)$ & (yrs) & $(\$ / y r)$ \\
\hline
\end{tabular}

A. WSHP System

Total System Less

Compressors and

Water Pump

60,775

25

7222

Compressors

$\begin{array}{lll}8375 & 10 & \frac{1423}{69,150}\end{array}$

Total

B. Electrjcal Resistance System(a)

Total System

$\$ 46,500$

25

$\$ 5,526$

(a) Cost estimate from Haskell Corp. Bellingham, WA. Discussion with Ed Frere of the Haskell Corp. Bellingham, WA. (May 1980). The Haskell Corp. is the mechanical subcontractor on the building. 


\title{
TABLE 6.15. Levelized Annual Costs for Alternative \\ Heating Methods - Salmon Hatchery
}

\author{
Electrical Resistance \\ System $\$ 9,640$ \\ Water Source Heat Pump \\ System \\ $\$ 10,516$
}

Electrical resistance heating is attractive for the salmon hatchery because of the relatively low electrical rates available there. The relative economics would be much closer or perhaps the WSHP would even be less expensive if the electrical rates were similar to those in Juneau.

\subsection{TECHNICAL VIABILITY OF WSHPS IN THE JUNEAU AREA}

The purpose of this section is to evaluate the technical viability of the 4 WSHP heating system designs presented in Chapter 5 . Since WSHP heating systems have much in cormon regardless of the specific application, the majority of the discussion in this chapter relates to WSHP applications in general (Section 6.3.1). The technical viability of the 4 specific cases are then evaluated and sumarized in Sections 6.3.2 through 6.3.5.

\subsubsection{General Considerations}

The most important factor necessary for a successful WSHP installation is availability of a water supply with acceptable temperature, quality, and quantity. One manufacturer's experience indicates that about $42 \%$ of the field problems associated with installations of their equipment were due to improperly designed, installed or maintained water systems. Only about 3\% of the field problems were due to faulty WSHP equipment (Wescorp 1980, p. 22).

Since the availability of both sea and ground water suitable for use in a WSHP is dependent upon the specific location of the structure to be heated, no overall conclusions can be drawn for the Juneau area. However, it appears that in a number of locations there is ground water suitable for use as a heat source for WSHPs. Information contained in the report Hydrologic Data of The Juneau Borough, Alaska (McConaghy 1969, pp. 57-59) indicates that ground water 
temperatures in the 40 to $46^{\circ} \mathrm{F}$ range are not uncommon in the Juneau area. As shown in Figure 4.1 sea water temperatures of at least $38^{\circ} \mathrm{F}$ are available all year in the Auke Bay area. Similar temperatures should be available in the deeper portions of the Gastineau Channel immediately in front of the downtown Juneau area.

The COP and heating capacity of WSHPs vary with the inlet water temperature. The COP of one model of a WSHP designed for low water temperature applications over the temperature range from 40 to $62^{\circ} \mathrm{F}$ is shown in Figure 6.1. As shown the COP varies from about 2.7 at $40^{\circ} \mathrm{F}$ to about 3.6 at $62^{\circ} \mathrm{F}$ (including nominal pump allowance).

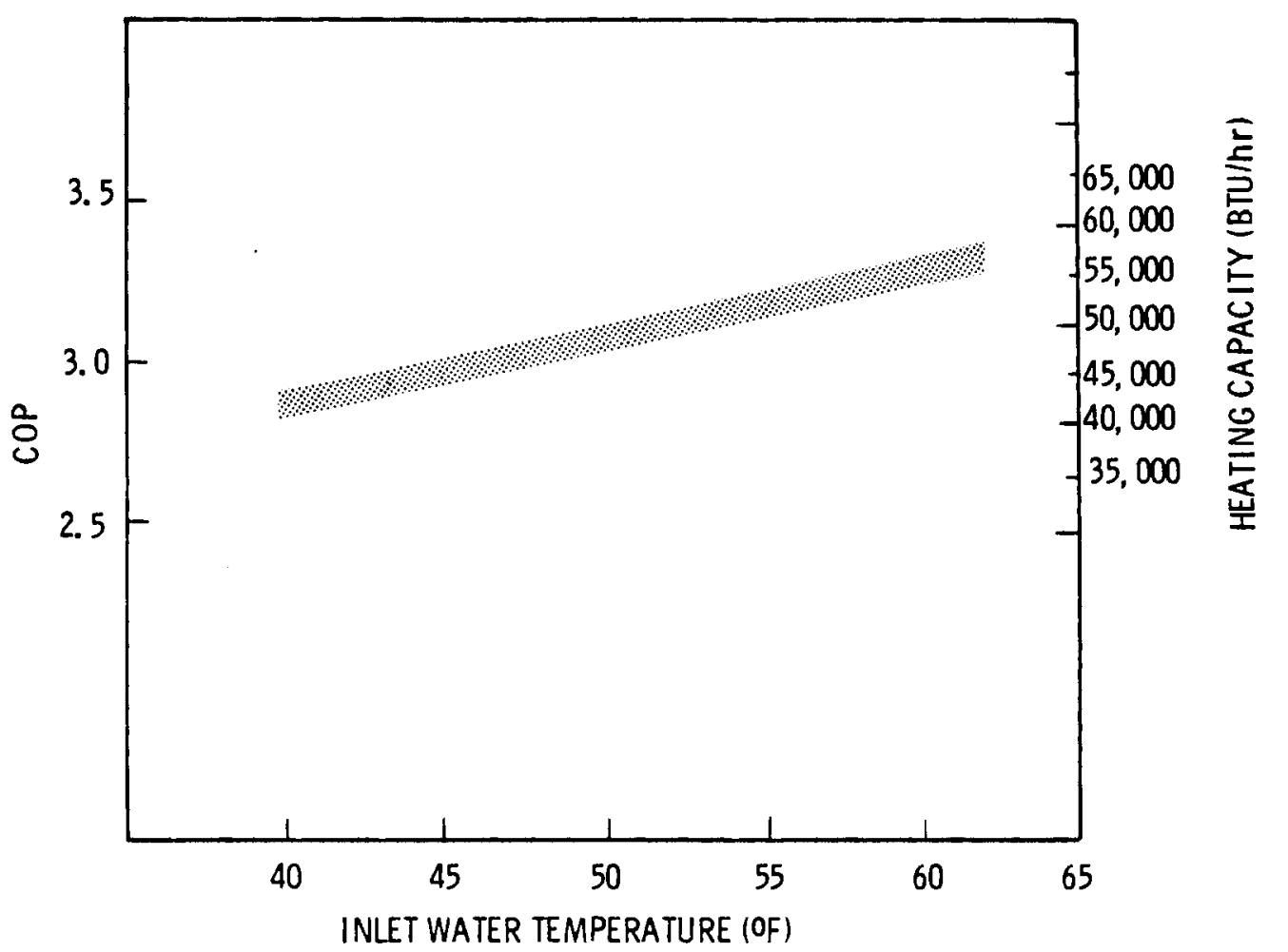

FIGURE 6.1. Coefficient of Performance and Heating Capacity Versus Inlet Water Temperature for Example WSHP

\footnotetext{
Source: Performance specifications for Thermal Energy Transfer Corporation (TETCO) Model HECWE-050 for $12 \mathrm{gpm}$ water flow rate and $1000 \mathrm{cfm}$ air flow rate. Heating capacity for the unit varies from 58,400 to $44,000 \mathrm{Btu} / \mathrm{hr}$ over this temperature range.
} 
To operate at such relatively low temperatures water source heat pump installations will require relatively high water flow rates. In general, a constant water flow rate of 15 to 20 gallons per minute (gpm) should be available for units in the 50,000 to $60,000 \mathrm{Btu} / \mathrm{hr}$ size and about 30 to $40 \mathrm{gpm}$ for units in the $100,000 \mathrm{Btu} / \mathrm{hr}$ range.

Residential heating using WSHPs requires relatively high water flow rates and water quantities compared to normal residential domestic water needs. A typical residence requires a peak flow rate of 5 to $15 \mathrm{gpm}$ depending upon the house size, family size, and number of fixtures. A WSHP requiring $15 \mathrm{gpm}$ would increase the maximum required water flow rate by 100 to $300 \%$.

A home normally requires from 50 to 100 gallons per day (gpd) per resident for domestic needs (200 to 400 gpd for a family of 4). A WSHP using $15 \mathrm{gpm}$ would need 21,600 gpd. While this maximum flow rate would be required only when the heat pump was operating at peak capacity, large quantities of water are required for WSHPS relative to normal domestic needs.

Because of the high water quantity and flow rates required, the water supply in any new building should be specifically designed for a WSHP. The water supply system in any prospective retrofit should be evaluated and modified if necessary to provide an adequate water flow rate.

A method of water disposal is also required with WSHP installations. In most applications using ground water an additional disposal well is probably the best method of disposing of the effluent water. In cases using sea water the most obvious disposal method is to return the water to the ocean or bay.

In the case of ground water the water disposal wells should be located some distance from the supply well and from other WSHP supply wells to insure that the cooled water is either not reused in the heat pump or has sufficient time to be warmed by the ground and surrounding water before reuse. Unfortunately, it is very difficult to predict what the minimum spacing should be. Well spacing depends upon a number of factors including length of the heating season, heat load, water flow rate, ground water temperature, and aquifer porosity. Minimum well spacing must be evaluated on a case-by-case basis. The onty case evaluated in this report that involves the use of a well is 
the Mendenhall Valley residence. It is beyond the scope of this project to determine the necessary well spacing for the Mendenhall Valley area. For the purposes of this study a well spacing of $75 \mathrm{ft}$. is assumed.

Disposal wells should typically be larger than the supply well to insure adequate flow. A common rule of thumb is to design the disposal well to have twice the capacity of the water supply well.(a)

Any applicable federal, state, and local regulations concerning the use of ground or sea water should be investigated. There do not appear to be any restrictions to the use or disposal of ground water in the Juneau area but there are federal and state regulations concerning the extraction and disposal of sea water.

One problem encountered in the use of low temperature water is the danger of the cooled outlet water freezing in the discharge piping. The effuent water will be in the 34 to $36^{\circ} \mathrm{F}$ range as it leaves the heatpump unit. Of course, the greatest danger of this happening is during the coldest times of the year when space heating is most necessary. Precautions must be taken to insure this will not happen. This can be accompolished by burying the pipes below the frost line and/or insulating the pipe.

The problems of using sea water as a heat source and some possible solutions to them were discussed in Chapter 4. No significant problems that would prevent the use of sea water were disclosed in this analysis.

No unusual water quality problems should prevent the use of ground water. One problem that is relatively common in ground water supply systems is calcium carbonate scaling. Calcium carbonate is present at some levels in all ground water. The amount of calcium carbonate dissolved in water is determined to a large extent by the amount of carbon dioxide in the water. Scaling problems occur when the condition of the water is changed to reduce the amount of carbon

(a) Presentation titled "Ground Water Geothermal Heat Pump Disposal Methods" given by Richard L. Shockley, President of Delta Well Co. Inc. at The National Ground Water Geothermal Heat Pump Conference and Exposition, Columbus, Ohio, February 11, 1980. 
dioxide and, hence, the amount of calcium carbonate dissolved in the water. Heating or reducing the pressure of water reduces the amount of carbon dioxide dissolved in water. Since the water flowing through WSHPs during the heating cycle is cooled, there is little danger for scaling in heating only applications. The use of pumps which draw a vacuum may promote calcium carbonate scaling since the pressure in the intake line is reduced. In general, perhaps the best way to learn if there will be water quality problems in a particular application is to see if there are any problems with other water systems in the area.

Heat pump installations (both air and water heat source) require higher interior air circulation rates than oil fired forced air heating systems since they have a lower temperature heat source. The source of heat in an $0 i 1$ furnace is a flame with a temperature in the 1000 to $2000^{\circ} \mathrm{F}$ range while the source of heat in a heat pump is compressed refrigerant with a temperature of about 130 to $150^{\circ} \mathrm{F}$. For this reason heat pump installations require larger air ducts to circulate more air to provide the same amount of heat as forced air oil furnaces. It is important to keep this fact in mind when considering retrofitting an existing structure with an oil furnace heating system with a heat pump. It is unlikely that the existing air ducting system designed for an $0 i 1$ furnace will be adequate for a heat pump installation.

In addition to the availability of a suitable water supply the other primary factor necessary for a successful WSHP application is proper installation and maintenance. In general, heat pump heating systems (both air and water heat source) are much more complex than electric resistance or oil heating systems. In some ways WSHPs are more complex than ASHPs since they require a water heat exchanger and the associated water supply and disposal systems rather than an air heat exchanger. Because of the more complex water supply and disposal system associated with WSHP systems they require more careful design, installation, and maintenance than ASHPS.

Because WSHP heating systems are not as common as other methods of heating, there are not many distributors or engineering firms with a great deal of experience in their design or installation. However, information is available from distributors, manufacturers, trade associations, and the open literature 
that would allow most mechanical and/or heating contractors to properly design and maintain WSHP heating systems. Initially it will be especially important to purchase units from manufacturers and distributors who will provide good delivery, installation, and warranty service in the Juneau area.

\subsubsection{New Residential Construction in the Mendenhall Valley}

This installation reflects standard current practice for WSHPS in residences. The low water temperature requires a relatively high water flow rate but these flow rates are well within standard residential practice. There should be no major technical problem associated with this installation.

\subsubsection{Filter Building at the Auke Bay Laboratory}

This installation involves the use of a residential sized WSHP utilizing sea water as a heat source. Any major technical problems associated with this installation will probably be associated with the use of sea water. These problems are discussed in Chapter 4.0.

The sea water at the Auke Bay laboratory is sent through a sand filter to remove the majority of the biological fouling organisms before use. Thus, the water used in the heatpump will be filtered. As a result, biological fouling should not be a problem in this installation.

The low temperature water available at Auke Bay well require relatively high water flow rates at design conditions (up to $17 \mathrm{gpm}$ ). This should not present a technological problem since such flow rates are common in many residential and small commercial operations.

\subsubsection{Warehouse on the Juneau Waterfront}

The technical considerations of this case are similar to those of the filter building case since both systems are using sea water. In this case, however, a chlorinator is used to eliminate biological fouling rather than a sand filter. The use of chlorinators for WSHP applications were discussed in Chapter 4.0.

\subsubsection{Salmon Hatchery}

In this case there should be no problems with the technical viability of the WSHP heating system. Fresh water is used as the source of heat so there shouldn't be any problems with corrosion or fouling. 


\subsection{EFFECTS ON ELECTRICAL AND FOSSIL FUEL USAGE}

The annual oil and electricity consumption for the alternative heating methods evaluated in this report are presented in Table 6.16. Use of WSHPs for heating in the Juneau area could reduce the use of fossil fuels while increasing the use of electricity. However, the increase in electricity use would be relatively low compared to electrical resistance heating since WSHPS offer seasonal COPS from 2.25 to 2.5. Substituting a WSHP for a oil-hydronic furnace in the typical residential example case would increase electrical consumption by about 24,000 $\mathrm{kWh}$ per year, while reducing $0 i 1$ consumption by about 2412 gallons per year. Substituting a WSHP for electrical resistance heating in the residential case would reduce the electricity consumed for heating from about 54,000 kWh per year to about 24,000 kWh per year.

As mentioned earlier in Chapter 2, the energy consumption estimates for the residence are similar to estimates for Juneau area residences contained in other recent studies (AEA 1979, p. 99 and CH2M Hill 1980, Appendix Table 8). These estimates are higher than the average "all electric" residential consumption of 24,216 kWh derived from 1977 electrical consumption data for the Juneau area (AEA 1979, p. 14).

There are several possible reasons for computed estimates to be higher than actual data suggests. They include:

TABLE 6.16. Annual $0 i 1$ and Electricity Consumption for Alternative Heating Methods

\begin{tabular}{|c|c|c|c|c|}
\hline & $\begin{array}{c}\text { Electrical } \\
\text { Resistance } \\
\text { (Electricity) } \\
\text { (kWh) } \\
\end{array}$ & $\begin{array}{l}0 \text { il Heat } \\
\text { (Fuel 0il) } \\
\text { (gal) }\end{array}$ & $\begin{array}{c}\text { ASHP } \\
\text { (Electricity) } \\
(\mathrm{kWh}) \\
\end{array}$ & $\begin{array}{c}\text { WSHP } \\
\text { (Electricity) } \\
\text { (kWh) } \\
\end{array}$ \\
\hline Residence & 53,875 & 2412 & 28,114 & 23,949 \\
\hline $\begin{array}{l}\text { Filter } \\
\text { Building }\end{array}$ & -- & 1645 & -- & 15,195 \\
\hline Warehouse & -- & 4853 & -- & 60,028 \\
\hline $\begin{array}{l}\text { Salmon } \\
\text { Hatchery }\end{array}$ & 205,033 & -- & -- & 82,013 \\
\hline
\end{tabular}


- The assumption is made in the calculated estimates that the house is heated to $70^{\circ} \mathrm{F}$ at all times. In actual practice the interior temperature may be reduced in portions of the house when not in use or in the entire house during evening and nighttime hours.

- In many cases in Juneau there is supplemental wood heat. The use of wood heat would also tend to reduce the actual consumption below the calculated estimates.

- The size and location of the houses included in the electrical consumption survey may not be representative of a new residence in the Mendenhall Valley. The Mendenhall Valley has a lower design temperature than areas closer to sea water.

- The quality of the insulation may be different in the homes used in the survey than the quality of the insulation assumed in the computated estimates. This probably would be a minor factor, however, since the residence in this report was relatively well insulated.

In the case of the Filter Building a WSHP would eliminate the use of oil for heating (1645 gal/yr) while increasing electrical consumption by 15,195 $\mathrm{kWh} / \mathrm{yr}$. In the warehouse case a WSHP heating system would reduce oil consumption by $4853 \mathrm{gal} / \mathrm{yr}$. For the case of the Snettisham salmon hatchery use of a WSHP heating system would reduce electrical consumption from 205,033 kWh to $82,013 \mathrm{kWh}$. 


\section{REFERENCES - Chapter 6.0}

Applied Economics Associates, Inc. March 1979. The Role of Electric Power in the Southeast Alaska Energy Economy. Prepared for the Alaska Power Administration, Juneau, Alaska.

CH2M Hi11. 1980 A Comparison of Home Heating Costs: Electricity Versus 0i1. Prepared for the Glacier Highway Electric Association, Auke Bay, Alaska.

McConaghy, J. A. 1969. Hydrologic Data of the Juneau Borough, Alaska. Prepared by United States Geological Survey in cooperation with the Greater Juneau Borough.

Wescorp Company. 1980. Procedures and Responsibilities for Normal and Extraordinary Maintenance of the Ground Water Geothermal Heat Pump. Andover, MA. 


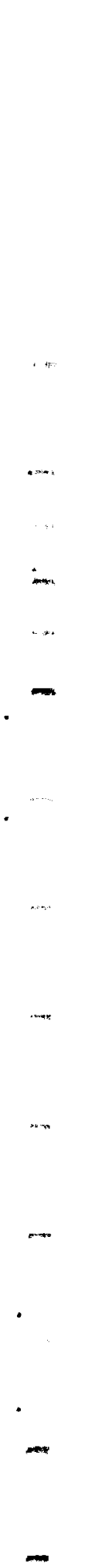




\subsection{RECOMMENDATIONS FOR VERIFICATION PROGRAM AND ADDITIONAL RESEARCH}

As pointed out in the introduction, the purposes of this project and report are to evaluate the technical and economic viability of WSHPs for use in the Juneau area and to identify potential verification projects. The purpose of this chapter is to present recommendations for a program to verify the results of the analyses contained in this report and to make some recommendations for further data gathering.

\subsection{RECOMMENDATIONS FOR VERIFICATION PROGRAM}

Based upon these analyses it appears that WSHPs are technically and economically viable in the Juneau area. There does not appear to be any technical problem involved in their use with either fresh or sea water which would prevent their use. And as discussed in Chapter 6 , WSHP heating systems offer life cycle heating costs that are generally comparable or slightly higher than other types of heating available in the Juneau area. However, because of the relatively low water temperatures, possible fouling and corrosion problems associated with the use of sea water, and uncertainties about the availability of proper design and maintance in Juneau, a field demonstration program to verify the results of this report should be conducted before a final recommendation is made as to the viability of WSHPS in the Juneau area. A residence in the Mendenhall Valley similar to the residential application evaluated in this report would probably be a good fresh water application although any residence either new or existing with an acceptable water supply should work just as we11. For the sea water demonstration an industrial or commercial building located near the water front similar to the NMFS, warehouse would be a logical choice.

A successful demonstration program should include the following factors:

1. A building located near a supply of fresh or sea water of acceptable temperature, quality, and quantity.

2. A qualified design engineer with a good knowledge of all aspects of WSHP practice. He should have a knowledge of both fresh and salt water piping and pumping applications in the Juneau area. 
3. A high quality WSHP of the correct size and specifications as well as quality components throughout the system.

4. It will be important for the heat pump manufacturer and distributor to be interested and supportive of the project. Since there are presently no distributors of WSHPs in the Juneau area it will be necessary to work with a distributor in the lower 48 (preferably in the Northwest).

5. A maintenance and field service program.

6. Proper instrumentation to monitor the performance of the demonstration units.

7. A data collection and analysis program to compile and evaluate the data.

8. It will be necessary to find out what federal, state and local, legal, environmental and regulatory restrictions there are on the use of fresh and sea water. There do not appear to be any state or local restrictions to the use of fresh water but there are federal and state restrictions on the use of and discharge into sea water.

9. A project manager to coordinate the overall program.

Each of these factors are briefly discussed below.

As discussed in Section 6.3, a key factor in any successful WSHP installation is a water supply with the proper temperature, quality, and flow rate. In the case of a fresh water demonstration site the minimum temperature should be $40^{\circ} \mathrm{F}$ with a 42 to $45^{\circ} \mathrm{F}$ supply preferable. The temperature should be monitored to insure that it remains above $40^{\circ} \mathrm{F}$ all year. The flow rate available depends upon the specific WSHP brand that is to be installed. As pointed out in Section 6.3, a constant flow rate of at least $15 \mathrm{gpm}$ should be available for units in the 50,000 to $60,000 \mathrm{Btu} / \mathrm{hr}$ size range (typical residential size). A constant water flow rate of about $30 \mathrm{gpm}$ would be necessary for units in the $100,000 \mathrm{Btu} / \mathrm{hr}$ range. 
Another key factor for a successful WSHP installation is a well engineered system. Because WSHP heating systems are not common at this point there are not many distributors or engineering firms with a great deal of experience in their design or installation. However, information is available from distributors, manufacturers, trade associations and in the open literature that would allow most mechanical and/or heating engineering firms to design WSHP heating systems. A knowledge of sea water piping and handling techniques would be necessary to design a sea water system.

Before proceeding with any demonstration project an engineer should prepare a detailed engineering design and cost estimate. The design work done as part of this project is on a feasibility level and should not be used for final design or cost estimating.

It will be especially important to purchase high quality units from manufacturers and distributors who will give good delivery and warranty service. They should be willing to work with the APA, the customer, and the design engineer to provide information for the design. If possible there should be a company distributor or serviceman either in Juneau or available on short notice.

In order to evaluate the performance of a WSHP field demonstration the installation should be properly instrumented. The following monitoring equipment should be installed.

1. A separate electrical meter for the WSHP and water pump.

2. Thermometers measuring the inlet and outlet water temperature.

3. An indoor and outdoor thermometer.

4. A method of measuring the air flow through the air handler.

5. A thermometer to measure the inlet and outlet air temperatures.

Data should be collected to allow the energy cost and COP of the units to be computed. This requires measuring the energy input (the electrical meter) and the heat output. The heat output can be determined either by knowing the air flow rate and temperature increase of the air going through the air handler or by knowing the heating requirements for the building. The building heating requirements can be determined from the indoor and outdoor temperatures and a heat load analysis of the building. 
As mentioned above, there are state and federal restrictions and permits required for the use and disposal of sea water as well as for the construction of intake and effluent systems. The U.S. Environmental Protection Agency (EPA) administers The National Pollutant Discharge Elimination System (NPDES) that was established by the Federal Clean Water Act. Under the NPDES any system disposing of sea water must have a permit if a pollutant or heat is added to the water. It is not clear whether an application that would cool the water such as heat pump would be classified as heat pollution or not. Certainly any system adding a biocide such as chlorine would be covered under NPDES standards.

Under Section 401 of the Federal Clean Water Act, the individual states must issue a permit stating that the prospective application meets applicable NPDES regulations before the EPA will issue a federal permit. The Alaska State Department of Environmental Conservation administers NPDES Section 401 for the state of Alaska. The southwest regional office of the Department of Environmental Conservation would be the first place to contact regarding a WSHP application using sea water. Questions regarding the NPDES could also be directed to the Seattle regional office of the EPA.

Any use of tidelands within the state requires a permit from the Alaska state Department of Natural Resources--Tidelands and Water Resource Office. Any dredging or filling would require a permit from the U.S. Corps of Engineers. Under Section 401 of the Clean Water Act the state would have to first issue a permit saying the dredging or filling meets the provisions of the NPDES.

Because of the great number of details associated with such a project a project manager should be assigned to facilitate the design, installation, and monitoring program.

\subsection{RECOMMENDATIONS FOR ADDITIONAL RESEARCH}

In the process of gathering data for this report, two additional applications of WSHPS, for space heating in Juneau and southeast Alaska were considered but not selected for further evaluation. One involves the use of WSHPs for district heating while the other involves the use of water from wells to heat buildings located in downtown Juneau. 
While there are many possible configurations for district heating with WSHPs, one that may be attractive for Juneau and other communities in southeast Alaska would use a large commercial size WSHP located close to sea water and smaller individual units located in the buildings to be heated. The large water to water heat pump would use sea water as a heat source and would heat a secondary circulating water supply. The secondary supply would be circulated through a piping system to the individual buildings. Each building would have a WSHP which would use the heated circulating water as a heat source. The water in the circulating loop would be maintained at about $50-60^{\circ} \mathrm{F}$ and as a result the individual WSHPS could operate with relatively high COPs with relatively low water flow rates.

Since the central WSHP would be located close to sea water the problems and cost associated with salt water fouling and corrosion could be kept to a minimum. The system would also be large enough to allow trained maintenance men to be available at all times to maintain the central heat pump as well as the units in the individual buildings. The operation of such a district heating system would be similar to an electrical or water utility. This would not only allow for a good maintenance program, as mentioned above, but could also allow the system to be financed using municipal financing methods which typically have lower interest rates than private financing methods. Such an arrangement could significantly reduce the cost of building a district heating system. Further evaluation would be necessary to see if such a system is technically or economically feasible in southeast Alaska.

The other application would use water from shallow wells to heat buildings located in downtown Juneau. A large part of downtown Juneau is located on tailings from the Treadwe 11 mines. These tailings are unconsolidated and very porous. In fact, the water level under many areas rises and falls with the tide. (a) This indicates that there should be ample water available for WSHPs as well as good possibilities for a water disposal. Because of the apparent high natural flow rate the cooled effluent water should be quickly dispersed.

(a) Discussions with John Spietz, City and Borough of Juneau, March 13, 1980. 
The temperature and extent of this resource should be investigated. Since the water flows through the ground it may pick up additional heat from the earth. If it appears that the water is of an acceptable temperature and qua1ity a feasibility level study should be undertaken to evaluate this as a water source for space heating in Juneau. 


\section{APPENDIX A}

\section{ADDITIONAL INFORMATION FROM WATER SOURCE HEAT PUMP MANFACTURER SURVEY}


ADDITIONAL INFORMATION FROM WATER SOURCE

HEAT PUMP MANUFACTURER SURVEY

This appendix contains addresses of Northwest Distributors and factory representatives of water source heat pumps reviewed in this report. Also included is a representative price list of water-to-air heat pumps by heating capacity and brand.

Thirteen of the nineteen brands of heat pumps reviewed in this report have Northwest Distributors or factory representatives (Table A.1). Northwest Distributors were located in the Seattle and Portland areas with the exception of one in Eugene, Oregon. In some cases there are both Seattle and Portland Distributors for the same heat pump brand. In most cases the Seattle Distributor was listed rather than the Portland Distributor. However, there appeared to be more Heat Pump Distributors in Portland than in Seattle.

The price-capacity chart (Table A.2) provides representative prices of water source heat pumps. This table should not be used for comparing prices between brands. Instead, it should be used to illustrate the range of costs for a given capacity. Prices are very sensitive to system options, operating conditions, and capacity. For heat pump selection, more detailed price information including shipping costs and sales tax should be sought. 


\section{TABLE A.1. Northwest Distributors of Water-to-Air Heat Pumps}

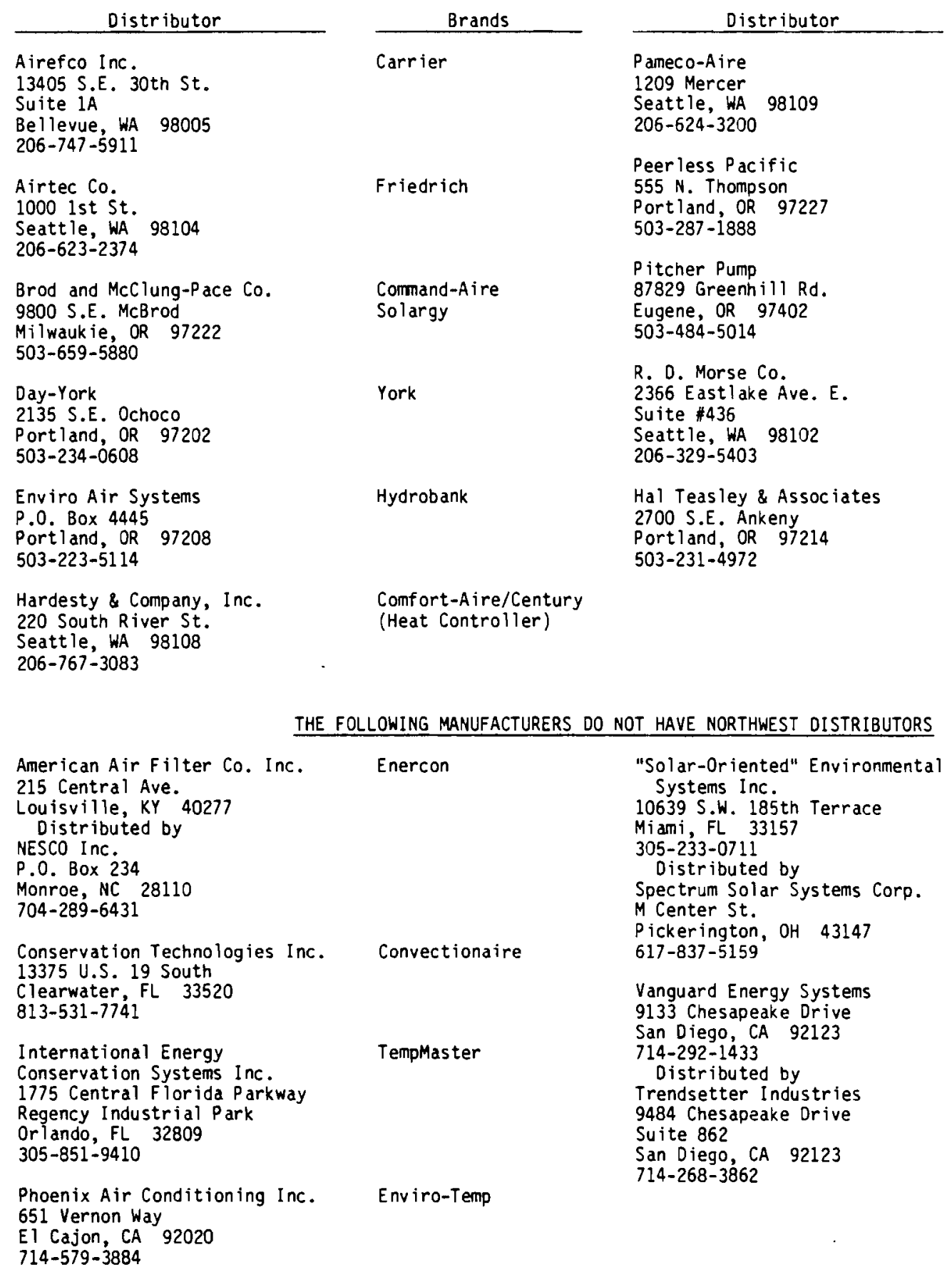


TABLE A.2. Price-Capacity Chart by Brand(a)

Heating Capacity (1000 BtuH)

\begin{tabular}{|c|c|c|c|c|c|c|c|c|}
\hline Brand & $20-30$ & $30-40$ & $40-60$ & $60-90$ & $90-150$ & $150-200$ & $200-300$ & $300-400$ \\
\hline Carrier & 1380 & 1804 & & & & & & \\
\hline Century & 813 & 1024 & 1612 & 1847 & & & & \\
\hline Comfort-A ire & & & & & 3775 & 6020 & 7723 & 12,090 \\
\hline \multicolumn{9}{|l|}{ Command-Aire } \\
\hline \multicolumn{9}{|c|}{ Convectionaire } \\
\hline Enercon & 1702 & 2126 & 2882 & & & & & \\
\hline Energy Miser & 1382 & 1545 & 1964 & 3124 & 5754 & & 11,796 & \\
\hline Enviro-Temp & & 2900 & 3289 & 4069 & 4460 & & & \\
\hline Friedrich & & & 1840 & 2660 & & & & \\
\hline Hydrobank & 1226 & 1681 & 1707 & 3648 & 4225 & & & \\
\hline KoldWave & 1239 & 1352 & 1628 & 2457 & 3354 & & & \\
\hline \multicolumn{9}{|l|}{ Northrup } \\
\hline \multicolumn{9}{|l|}{ Singer } \\
\hline \multicolumn{9}{|l|}{ SOESI } \\
\hline \multicolumn{9}{|l|}{ Solargy } \\
\hline TempMaster & 3000 & 3263 & 4281 & 6063 & 9700 & 10,981 & 18,300 & 23,000 \\
\hline TETCO & & & 1950 & & & & & \\
\hline Vanguard & 2814 & 3418 & 3895 & 5105 & & & & \\
\hline \multicolumn{9}{|l|}{ Whalen } \\
\hline York & 1300 & 1450 & 2000 & & & & & \\
\hline
\end{tabular}

(a) This table gives approximate retail prices supplied by distributors. No transporation costs are included. In some cases, there are several models of a particular brand that fall into the capacity range of a single column. In these cases, the model closest to the center of the range was choosen. In addition, prices for different brands reflect different system options and electrical characteristics. When only dealer prices were available, a 25\% markup was included. These factors should be considered in reviewing these prices. 


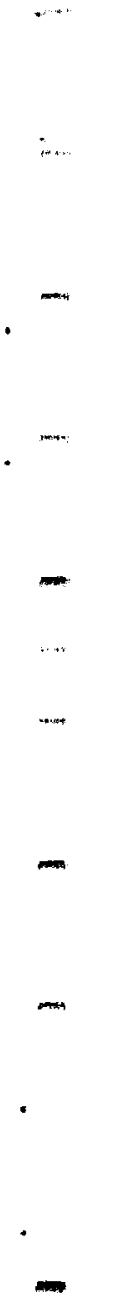

nin 


\section{APPENDIX B}

HEAT LOAD CALCULATIONS 
TABLE B.1. Heat Load Calculations for Residence

$\begin{array}{ll}\text { Outdoor Design Temperature }=-15^{\circ} \mathrm{F} & \text { Design Temperature Difference }=85^{\circ} \mathrm{F} \\ \text { Interior Design Temperature }=70^{\circ} \mathrm{F} & \text { Total Heat Load }=48,401 \mathrm{Btu} / \mathrm{hr}\end{array}$

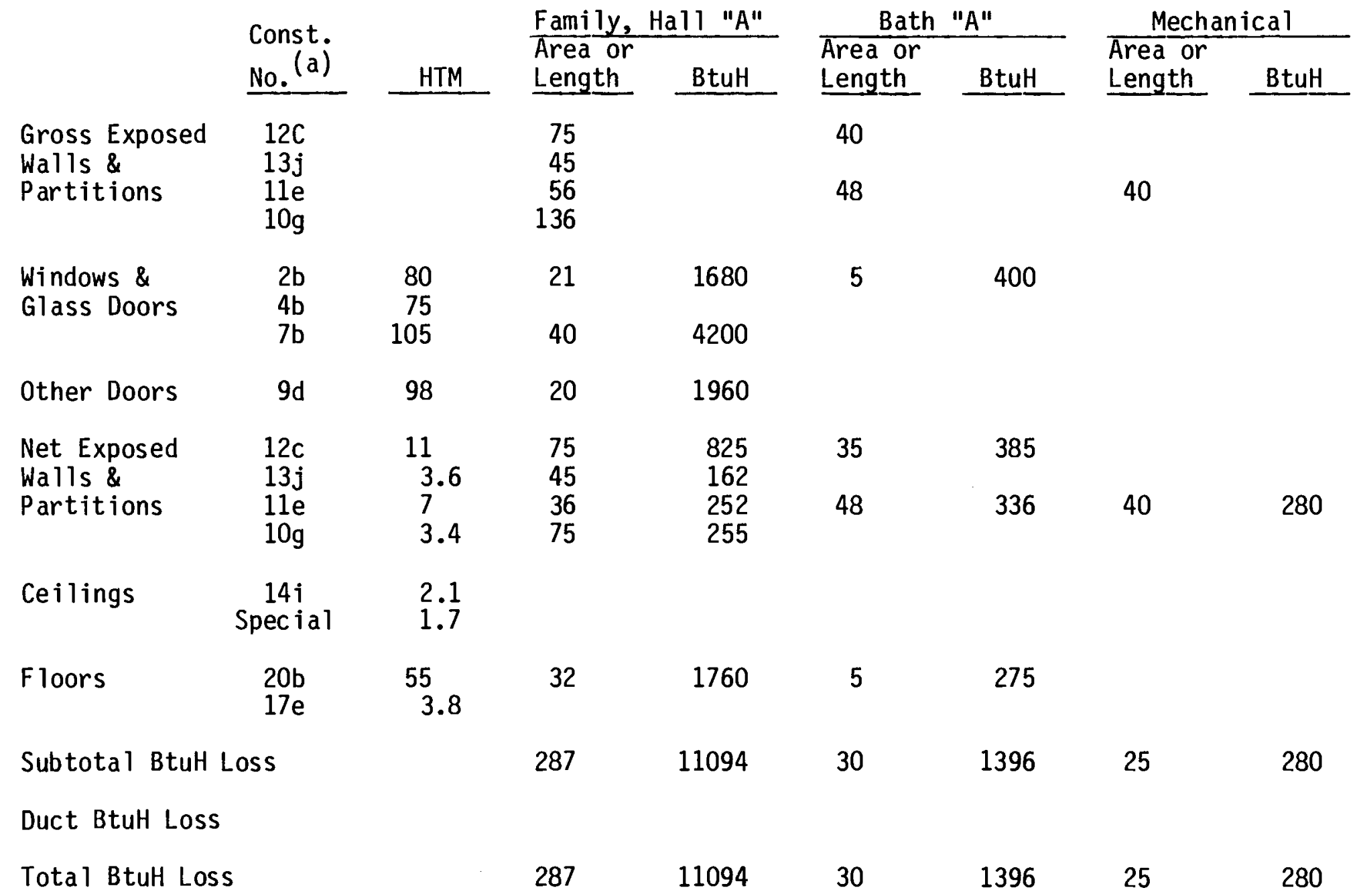

(a) From ACCA Manual J. Table 2 (ACCA 1975, p. 31-33). Heat Loss and Heat Gain Calculation Work sheet format from (ACCA 1975, p. 13). 
TABLE B.1. (contd)

\begin{tabular}{|c|c|c|c|c|c|c|c|c|}
\hline & & & Stu & & Master & essing & Bath & \\
\hline & No. (a) & HTM & $\begin{array}{l}\text { Area or } \\
\text { Length }\end{array}$ & BtuH & $\begin{array}{l}\text { Area or } \\
\text { Length }\end{array}$ & BtuH & $\begin{array}{l}\text { Area or } \\
\text { Length }\end{array}$ & BtuH \\
\hline $\begin{array}{l}\text { Gross Exposed } \\
\text { Walls \& } \\
\text { Partitions }\end{array}$ & $\begin{array}{l}12 \mathrm{C} \\
13 \mathrm{j} \\
11 \mathrm{e} \\
10 \mathrm{~g}\end{array}$ & & $\begin{array}{r}137 \\
82 \\
40\end{array}$ & & 255 & & & \\
\hline $\begin{array}{l}\text { Windows \& } \\
\text { Glass Doors }\end{array}$ & $\begin{array}{l}2 \mathrm{~b} \\
4 \mathrm{~b} \\
7 \mathrm{~b}\end{array}$ & $\begin{array}{r}80 \\
75 \\
105\end{array}$ & 16 & 1280 & 30 & 2400 & & \\
\hline Other Doors & $9 e$ & & & & & & & \\
\hline $\begin{array}{l}\text { Net Exposed } \\
\text { Walls \& } \\
\text { Partitions }\end{array}$ & $\begin{array}{l}12 \mathrm{c} \\
13 \mathrm{j} \\
11 \mathrm{e} \\
10 \mathrm{~g}\end{array}$ & $\begin{array}{c}11 \\
3.6 \\
7 \\
3.4\end{array}$ & $\begin{array}{r}121 \\
82 \\
40\end{array}$ & $\begin{array}{r}1331 \\
295 \\
280\end{array}$ & 225 & 765 & & \\
\hline Ceilings & $\begin{array}{c}14 i \\
\text { Special }\end{array}$ & $\begin{array}{l}2.1 \\
1.7\end{array}$ & & & 210 & 441 & 45 & 95 \\
\hline Floors & $\begin{array}{l}20 \mathrm{~b} \\
17 \mathrm{e}\end{array}$ & $\begin{array}{l}55 \\
3.8\end{array}$ & 27 & 1485 & 210 & 798 & 35 & 133 \\
\hline Subtotal BtuH & Loss & & 168 & 4671 & 210 & 4404 & 45 & 228 \\
\hline Duct BtuH Loss & & & & & 0.2 & 881 & 0.2 & 46 \\
\hline Total BtuH Los & & & 168 & 4671 & 210 & 5285 & 45 & 274 \\
\hline
\end{tabular}

(a) From ACCA Manual J. Table 2 (ACCA 1975, p. 31-33). Heat Loss and Heat Gain Calculation Worksheet format from (ACCA 1975, p. 13). 
TABLE B.1. (contd)

\begin{tabular}{llll}
$\begin{array}{c}\text { Const. } \\
\text { (a) }\end{array}$ & $\begin{array}{c}\text { Kitchen } \\
\text { Area or } \\
\text { No. }\end{array}$ HTM Area or \\
\hline
\end{tabular}

Gross Exposed $12 \mathrm{C}$

Walls \& $\quad 13 j$

Partitions $\quad 11 \mathrm{e}$

\begin{tabular}{|c|c|c|c|c|c|c|c|c|}
\hline \multirow[b]{2}{*}{$\begin{array}{l}\text { Windows \& } \\
\text { Glass Doors }\end{array}$} & $10 \mathrm{~g}$ & \multicolumn{3}{|c|}{32} & \multicolumn{2}{|l|}{80} & \multicolumn{2}{|l|}{176} \\
\hline & $\begin{array}{l}2 b \\
4 b \\
7 b\end{array}$ & $\begin{array}{r}80 \\
75 \\
105\end{array}$ & 5 & 400 & 21 & 1680 & 40 & 4200 \\
\hline Other Doors & $9 e$ & 191 & & & & & & \\
\hline $\begin{array}{l}\text { Net Exposed } \\
\text { Walls \& } \\
\text { Partitions }\end{array}$ & $\begin{array}{l}12 \mathrm{c} \\
13 \mathrm{j} \\
11 \mathrm{e} \\
10 \mathrm{~g}\end{array}$ & $\begin{array}{l}11 \\
3.6 \\
7 \\
3.4\end{array}$ & 127 & 92 & 59 & 201 & 136 & 462 \\
\hline Ceilings & $\begin{array}{c}14 i \\
\text { Spec ial }\end{array}$ & $\begin{array}{l}2.1 \\
1.7\end{array}$ & 24 & 50 & 120 & 252 & 120 & 252 \\
\hline Floors & $\begin{array}{l}20 \mathrm{~b} \\
17 \mathrm{e}\end{array}$ & $\begin{array}{l}55 \\
3.8\end{array}$ & 12 & 46 & & & & \\
\hline Subtotal Btul & Loss & & 24 & 588 & 120 & 2133 & 120 & 4914 \\
\hline Duct BtuH Los & & & 0.2 & 118 & & & & \\
\hline Total BtuH Le & & & 24 & 706 & 120 & 2133 & 120 & 4914 \\
\hline
\end{tabular}

(a) From ACCA Manual J. Table 2 (ACCA 1975, p. 31-33). Heat Loss and Heat Gain Calculation Work sheet format from (ACCA 1975, p. 13). 
TABLE B.1. (contd)

\begin{tabular}{|c|c|c|c|c|c|c|c|}
\hline \multirow{2}{*}{$\begin{array}{l}\text { Const. } \\
\text { No. (a) }\end{array}$} & & \multicolumn{2}{|c|}{ Living Room } & \multicolumn{2}{|c|}{ Entry \& Hall "C" } & \multicolumn{2}{|c|}{$\mathrm{Hall}$ "B" } \\
\hline & HTM & $\begin{array}{l}\text { Area or } \\
\text { Length }\end{array}$ & BtuH & $\begin{array}{l}\text { Area or } \\
\text { Length }\end{array}$ & BtuH & $\begin{array}{l}\text { Area or } \\
\text { Length }\end{array}$ & BtuH \\
\hline
\end{tabular}

\begin{tabular}{|c|c|c|c|c|c|c|c|c|}
\hline $\begin{array}{l}\text { Gross Exposed } \\
\text { Walls \& } \\
\text { Partitions }\end{array}$ & $\begin{array}{l}12 \mathrm{C} \\
13 \mathrm{j} \\
11 \mathrm{e} \\
10 \mathrm{~g}\end{array}$ & & 248 & & $\begin{array}{r}58 \\
123\end{array}$ & & & \\
\hline $\begin{array}{l}\text { Windows \& } \\
\text { Glass Doors }\end{array}$ & $\begin{array}{l}2 b \\
4 b \\
7 b\end{array}$ & $\begin{array}{r}80 \\
75 \\
105\end{array}$ & $\begin{array}{l}20 \\
13\end{array}$ & $\begin{array}{r}1600 \\
975\end{array}$ & 13 & 975 & & \\
\hline Other Doors & $9 e$ & 191 & & & 20 & 3820 & & \\
\hline $\begin{array}{l}\text { Net Exposed } \\
\text { Walls \& } \\
\text { Partitions }\end{array}$ & $\begin{array}{l}12 \mathrm{c} \\
13 \mathrm{j} \\
11 \mathrm{e} \\
10 \mathrm{~g}\end{array}$ & $\begin{array}{l}11 \\
3.6 \\
7 \\
3.4\end{array}$ & 215 & 731 & $\begin{array}{l}58 \\
90\end{array}$ & $\begin{array}{l}406 \\
306\end{array}$ & & \\
\hline Ceilings & $\begin{array}{c}14 i \\
\text { Special }\end{array}$ & $\begin{array}{l}2.1 \\
1.7\end{array}$ & $\begin{array}{l}116 \\
116\end{array}$ & $\begin{array}{l}244 \\
197\end{array}$ & $\begin{array}{l}64 \\
47\end{array}$ & $\begin{array}{r}134 \\
80\end{array}$ & 60 & 126 \\
\hline Floors & $\begin{array}{l}20 \mathrm{~b} \\
17 \mathrm{e}\end{array}$ & $\begin{array}{c}55 \\
3.8\end{array}$ & & & 110 & 418 & 60 & 228 \\
\hline \multicolumn{2}{|c|}{ Subtotal BtuH Loss } & & 210 & 3747 & 104 & 6139 & 60 & 354 \\
\hline \multicolumn{3}{|l|}{ Duct BtuH Loss } & & & 0.2 & 1228 & 0.2 & 71 \\
\hline \multicolumn{3}{|c|}{ Total BtuH Loss } & -210 & 3747 & 104 & 7367 & 60 & 425 \\
\hline
\end{tabular}

(a) From ACCA Manual J. Table 2 (ACCA 1975, p. 31-33). Heat Loss and Heat Gain Calculation Work sheet format from (ACCA 1975, p. 13). 


\begin{tabular}{|c|c|c|c|c|c|c|c|c|}
\hline & & & Bedr & m 2 & Bed & n 3 & Total & House \\
\hline & $\begin{array}{l}\text { Const. } \\
\text { No. (a) }\end{array}$ & HTM & $\begin{array}{l}\text { Area or } \\
\text { Length }\end{array}$ & BtuH & $\begin{array}{l}\text { Area or } \\
\text { Length }\end{array}$ & BtuH & $\begin{array}{l}\text { Area or } \\
\text { Length }\end{array}$ & BtuH \\
\hline $\begin{array}{l}\text { Gross Exposed } \\
\text { Walls \& } \\
\text { Partitions }\end{array}$ & $\begin{array}{l}12 \mathrm{C} \\
13 \mathrm{j} \\
11 \mathrm{e} \\
10 \mathrm{~g}\end{array}$ & & 216 & & 128 & & & \\
\hline $\begin{array}{l}\text { Windows \& } \\
\text { Glass Doors }\end{array}$ & $\begin{array}{l}2 b \\
4 b \\
7 b\end{array}$ & $\begin{array}{r}80 \\
75 \\
105\end{array}$ & 15 & 1200 & 15 & 1200 & & \\
\hline Other Doors & $9 e$ & 191 & & & & & & \\
\hline $\begin{array}{l}\text { Net Exposed } \\
\text { Walls \& } \\
\text { Partitions }\end{array}$ & $\begin{array}{l}12 \mathrm{c} \\
13 \mathrm{j} \\
11 \mathrm{e} \\
10 \mathrm{~g}\end{array}$ & $\begin{array}{l}11 \\
3.6 \\
7 \\
3.4\end{array}$ & 199 & 677 & 113 & 384 & & \\
\hline Ceilings & $\begin{array}{c}14 i \\
\text { Special }\end{array}$ & $\begin{array}{l}2.1 \\
1.7\end{array}$ & 158 & 332 & 128 & 269 & & \\
\hline Floors & $\begin{array}{l}20 \mathrm{~b} \\
17 \mathrm{e}\end{array}$ & $\begin{array}{l}55 \\
3.8\end{array}$ & 158 & 600 & 113 & 429 & & \\
\hline Subtotal BtuH & Loss & & 158 & 2809 & 128 & 2282 & 1689 & 45039 \\
\hline Duct BtuH Loss & & & 0.2 & 562 & 0.2 & 456 & & 3362 \\
\hline Total BtuH Lo & & & 158 & 3371 & 128 & 2738 & 1689 & 48401 \\
\hline
\end{tabular}

(a) From ACCA Manual J. Table 2 (ACCA 1975, p. 31-33). Heat Loss and Heat Gain Calculation Work sheet format from (ACCA 1975, p. 13). 
TABLE B.2. Heat Load Calculation Data for Residence

Ceiling - Wood trusses a 16" OC, 12" fiberglass insulation (R-38), vaulted ceiling over entry and living room

Walls - Al1 exterior wa $11 \mathrm{~s} 2 \times 6$ studs $016^{\prime \prime}$ OC, $51 / 2^{\prime \prime}$ fiberglass insulation (R-19)

Windows - A11 windows double glazed aluminum frame with thermal break (Letters refer to Figure 5.1)
(A)
(2)
$31-0 " 1 \times 5$
$\times 5^{\prime}-0 "$
Vert. Sliding
(B)
$6^{\prime}-0 " \times 3^{\prime}-0 "$ sliding
(C)
$2^{\prime}-0 " \times 5^{\prime}-0 "$ Fixed
(D)
(2) $2^{\prime}-0^{\prime \prime} \times 5^{\prime}-0^{\prime \prime}$ Vert. Sliding
(E)
$3^{\prime}-0^{\prime \prime} \times 5^{\prime}-0^{\prime \prime}$ Vert. Sliding
(F)
(2) $3^{\prime}-0^{\prime \prime} \times 3^{\prime}-0 "$ Fixed
(G)
$1^{\prime}-0 " 1 \times 3^{\prime}-0^{\prime \prime}$ Vert. Sliding
(H)
(2) $3^{\prime}-0^{\prime \prime} \times 4^{\prime}-0^{\prime \prime}$ Vert. Sliding

Doors - (Numbers refer to Figure 5.1)
(1)
$3^{\prime}-0^{\prime \prime} \times 6^{\prime}-8^{\prime \prime}-13 / 4^{\prime \prime}$ Solid Core Wood
(2)
$6^{\prime}-0^{\prime \prime} \times 6^{\prime}-8^{\prime \prime}$ Slider (double glazed with
(3) aluminum frame and thermal break)
(3) 10'-0" $\times 7^{\prime}-0 "$ Overhead Wood Panel

Floor - Main Leve1 - 2x10" joists a 16" OC, all exposed floors insulated to $\mathrm{R}-19$

Lower Level - Concrete slab 
TABLE B.3. Heat Load Calculations for Filter Building

Outdoor Design Temperature $=-5^{\circ} \mathrm{F}$

Interior Design Temperature $=60^{\circ} \mathrm{F}$
Design Temperature Difference $=65^{\circ} \mathrm{F}$

Total Heat Load $=56,019 \mathrm{Btu} / \mathrm{hr}$

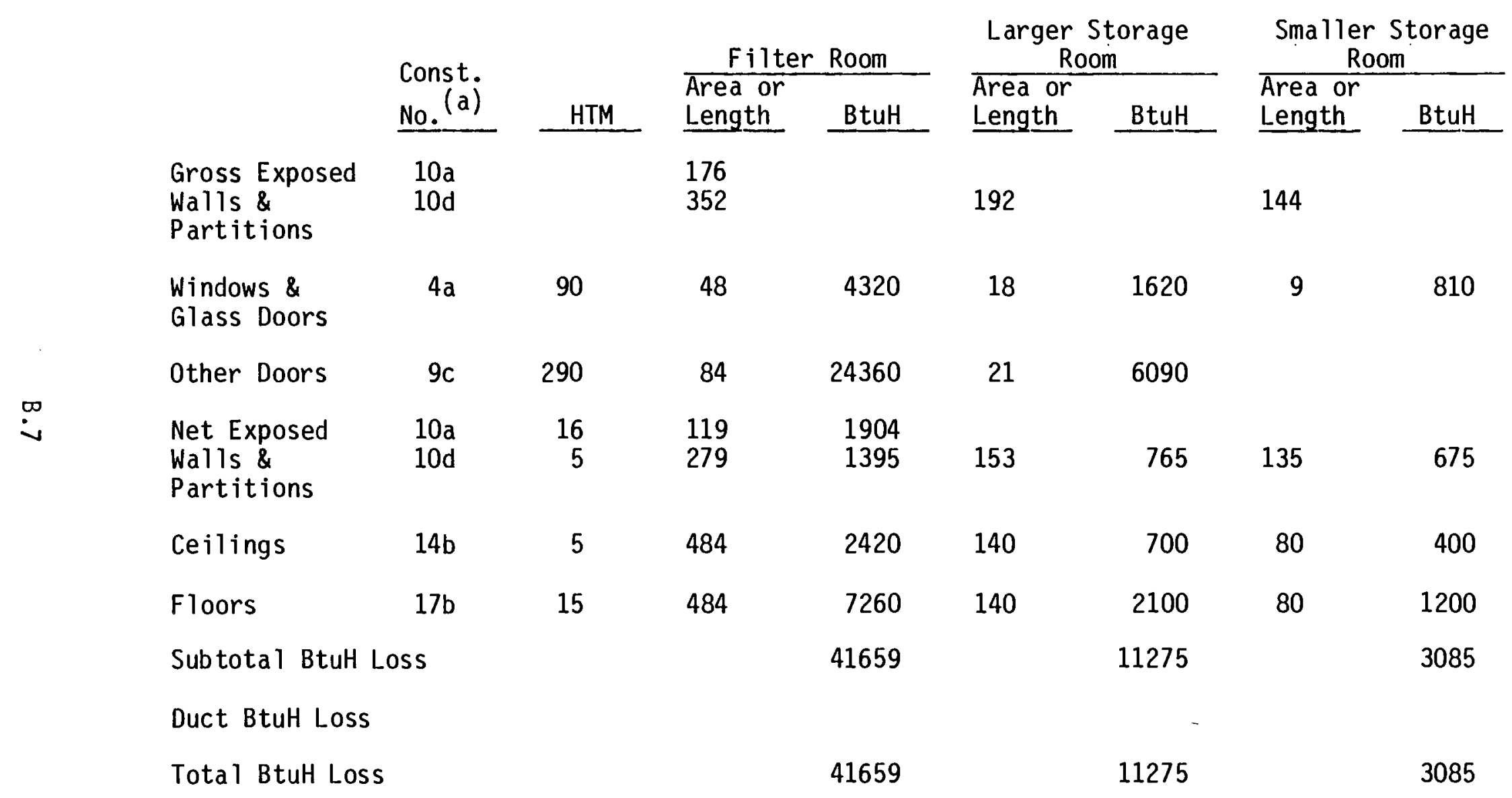

(a) From ACCA Manual J. Table 2 (ACCA 1975, p. 31-33). Heat Loss and Heat Gain Calculation Worksheet format from (ACCA 1975, p. 13). 
TABLE B.4. Heat Load Calculation Data for Filter Building Ceiling - Wood trusses o 16" OC, $31 / 2^{\prime \prime}$ fiberglass insulation, no interior sheathing in filter room, sheetrock in storage rooms

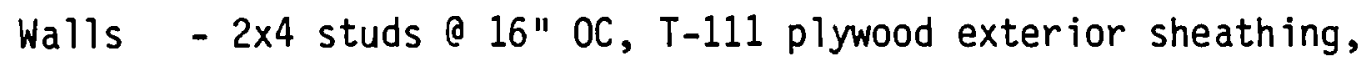
$31 / 2$ " fiberglass insulation and sheathing on all walls except west wall of filter room, west wall of filter room is not insulated

Windows - (Letters refer to Figure 5.2)
(A) $3^{\prime}-0^{\prime \prime} \times 4^{\prime}-0^{\prime \prime}$ Fixed Single Glass
(B) $3^{\prime}-0^{\prime \prime} \times 4^{\prime}-0^{\prime \prime}$ Fixed Single Glass
(C) $3^{\prime}-0^{\prime \prime} \times 4^{\prime}-0 "$ Fixed Single Glass
(D) $3^{\prime}-0^{\prime \prime} \times 3^{\prime}-0^{\prime \prime}$ Bottom Opening Single Glass
(E) $3^{\prime}-0^{\prime \prime} \times 3^{\prime}-0 "$ Bottom Opening Single Glass
(F) $3^{\prime}-0^{\prime \prime} \times 3^{\prime}-0^{\prime \prime}$ Bottom Opening Single Glass
(G) $3^{\prime}-0^{\prime \prime} \times 4^{\prime}-0^{\prime \prime}$ Fixed Single Glass

Doors - (Numbers refer to Figure 5.2)
(1) $9^{\prime}-0^{\prime \prime} \times 7^{\prime}-0 "$ Overhead Metal Panel
(2) $3^{\prime}-0^{\prime \prime} \times 6^{\prime}-8^{\prime \prime}$ Interior door (single $3 / 8^{\prime \prime}$ plywood with $13 / 4$ " frame)
(3) $3^{\prime}-0^{\prime \prime} \times 6^{\prime}-8$ " Interior door (single $3 / 8^{\prime \prime}$ plywood with $13 / 4$ " frame)

Floor - 3/4" plywood floor on $2 \times 6 "$ joists a 16 " OC on blocks raised about 8 " above ground 
TABLE B.5. Heat Load Calculations for Warehouse

$$
\begin{array}{ll}
\text { Outdoor Design Temperature }=-5^{\circ} \mathrm{F} & \text { Design Temperature Difference }=65^{\circ} \mathrm{F} \\
\text { Interior Design Temperature }=60^{\circ} \mathrm{F} & \text { Total Heat Load }=213,772 \mathrm{Btu} / \mathrm{hr}
\end{array}
$$

\begin{tabular}{|c|c|c|c|c|c|c|c|c|}
\hline & \multirow{2}{*}{$\begin{array}{l}\text { Const. } \\
\text { No. (a) }\end{array}$} & & \multicolumn{2}{|c|}{ Garage } & \multicolumn{2}{|c|}{ Office } & \multicolumn{2}{|c|}{ Woodshop } \\
\hline & & HTM & $\begin{array}{l}\text { Area or } \\
\text { Length }\end{array}$ & BtuH & $\begin{array}{l}\text { Area or } \\
\text { Length }\end{array}$ & BtuH & $\begin{array}{l}\text { Area or } \\
\text { Length }\end{array}$ & BtuH \\
\hline $\begin{array}{l}\text { Gross Exposed } \\
\text { Walls \& } \\
\text { Partitions }\end{array}$ & $\begin{array}{l}1 \\
2\end{array}$ & & 3738 & & 210 & & 808 & \\
\hline $\begin{array}{l}\text { Windows \& } \\
\text { Glass Doors }\end{array}$ & $\begin{array}{l}2 b \\
4 b\end{array}$ & $\begin{array}{l}65 \\
55\end{array}$ & & & 48 & 3120 & $\begin{array}{r}144 \\
96\end{array}$ & $\begin{array}{l}9360 \\
5280\end{array}$ \\
\hline 0ther Doors & $9 b$ & 155 & 277 & 42935 & & & 21 & 3255 \\
\hline $\begin{array}{l}\text { Net Exposed } \\
\text { Walls \& } \\
\text { Partitions }\end{array}$ & $\begin{array}{l}1 \\
2\end{array}$ & $\begin{array}{l}6.5 \\
5.0\end{array}$ & 346 & 22496 & 162 & 810 & 547 & 2735 \\
\hline Ceilings & 1 & 6.5 & 3540 & 23010 & & & & \\
\hline Floors & $21 a$ & 125 & 178 & 22250 & 20 & 2500 & 77 & 9625 \\
\hline Subtotal BtuH & oss & & & 110691 & & 6430 & & 30255 \\
\hline Duct BtuH Loss & & & & & & & & \\
\hline Total BtuH Los & & & & 110691 & & 6430 & & 30255 \\
\hline
\end{tabular}

(a) From ACCA Manual J. Table 2 (ACCA 1975, p. 31-33). Heat Loss and Heat Gain Calculation Worksheet format from (ACCA 1975, p. 13). 
TABLE B.5. (contd)

\begin{tabular}{|c|c|c|c|c|c|c|c|c|}
\hline & & & Mach ir & Shop & Toil & Room & Boile & Room \\
\hline & No. (a) & HTM & $\begin{array}{l}\text { Area or } \\
\text { Length }\end{array}$ & BtuH & $\begin{array}{l}\text { Area or } \\
\text { Length }\end{array}$ & BtuH & $\begin{array}{l}\text { Area or } \\
\text { Length }\end{array}$ & BtuH \\
\hline $\begin{array}{l}\text { Gross Exposed } \\
\text { Walls \& } \\
\text { Partitions }\end{array}$ & $\begin{array}{l}1 \\
2\end{array}$ & & 693 & & 95 & & 105 & \\
\hline $\begin{array}{l}\text { Windows \& } \\
\text { Glass Doors }\end{array}$ & $2 \mathrm{~b}$ & 65 & 168 & 10920 & 24 & 1560 & & \\
\hline Other Doors & $9 b$ & 155 & & & & & 42 & 6510 \\
\hline $\begin{array}{l}\text { Net Exposed } \\
\text { Walls \& } \\
\text { Partitions }\end{array}$ & 2 & 5.0 & 525 & 2625 & 71 & 355 & 63 & 315 \\
\hline Ceilings & 1 & & & & & & & \\
\hline Floors & $21 a$ & 125 & 66 & 8250 & 9 & 1125 & 10 & 1250 \\
\hline Subtotal BtuH & -oss & & & 21795 & & 3040 & & 8075 \\
\hline Duct BtuH Loss & & & & & & & & \\
\hline Total BtuH Los & & & & 21795 & & 3040 & & 8075 \\
\hline
\end{tabular}

(a) From ACCA Manual J. Table 2 (ACCA 1975, p. 31-33). Heat Loss and Heat Gain Calculation Worksheet format from (ACCA 1975 , p. 13). 
TABLE B.5. (contd)

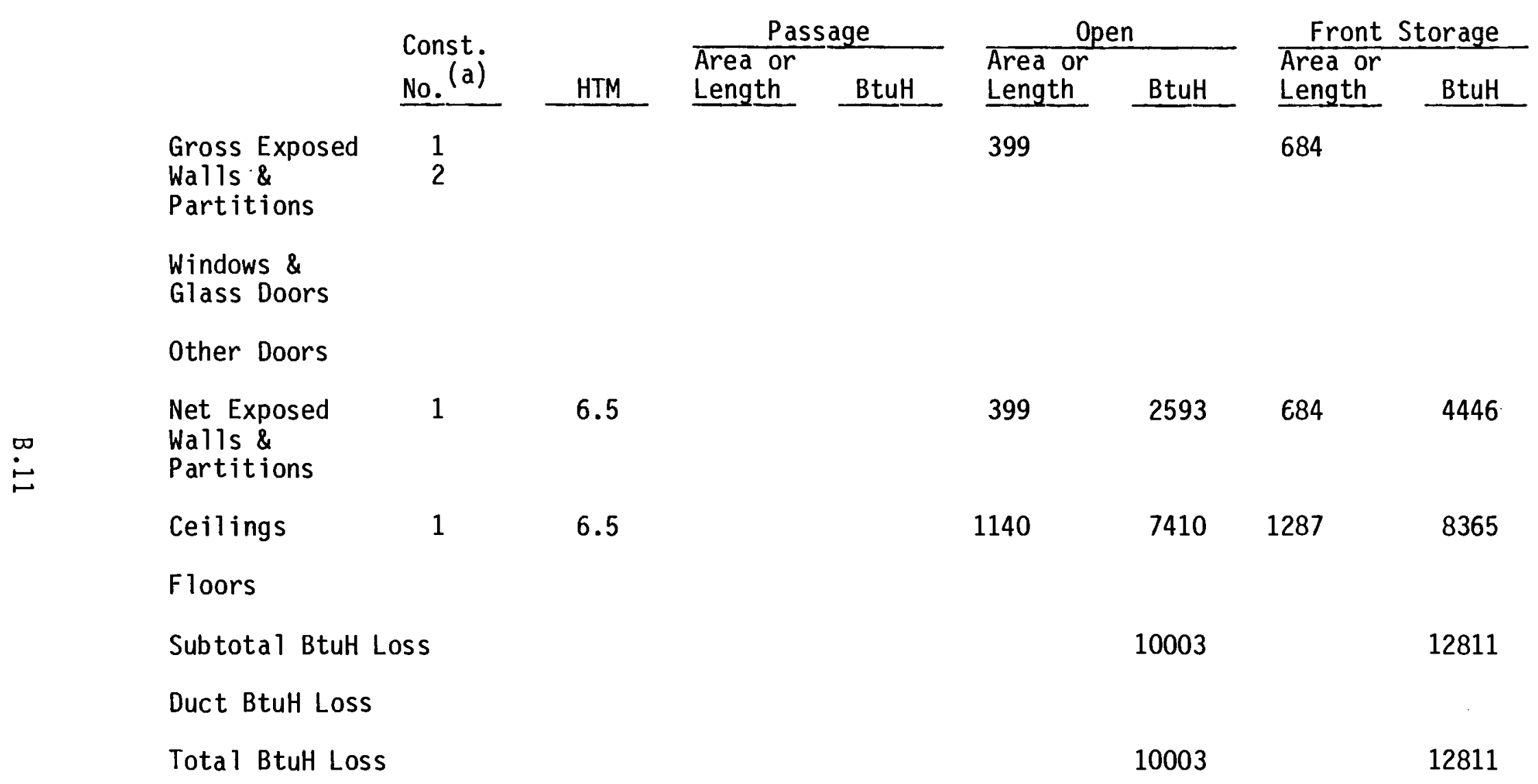

(a) From ACCA Manual J. Table 2 (ACCA 1975, p. 31-33). Heat Loss and Heat Gain Calculation Worksheet format from (ACCA 1975, p. 13). 
TABLE B.5. (contd)

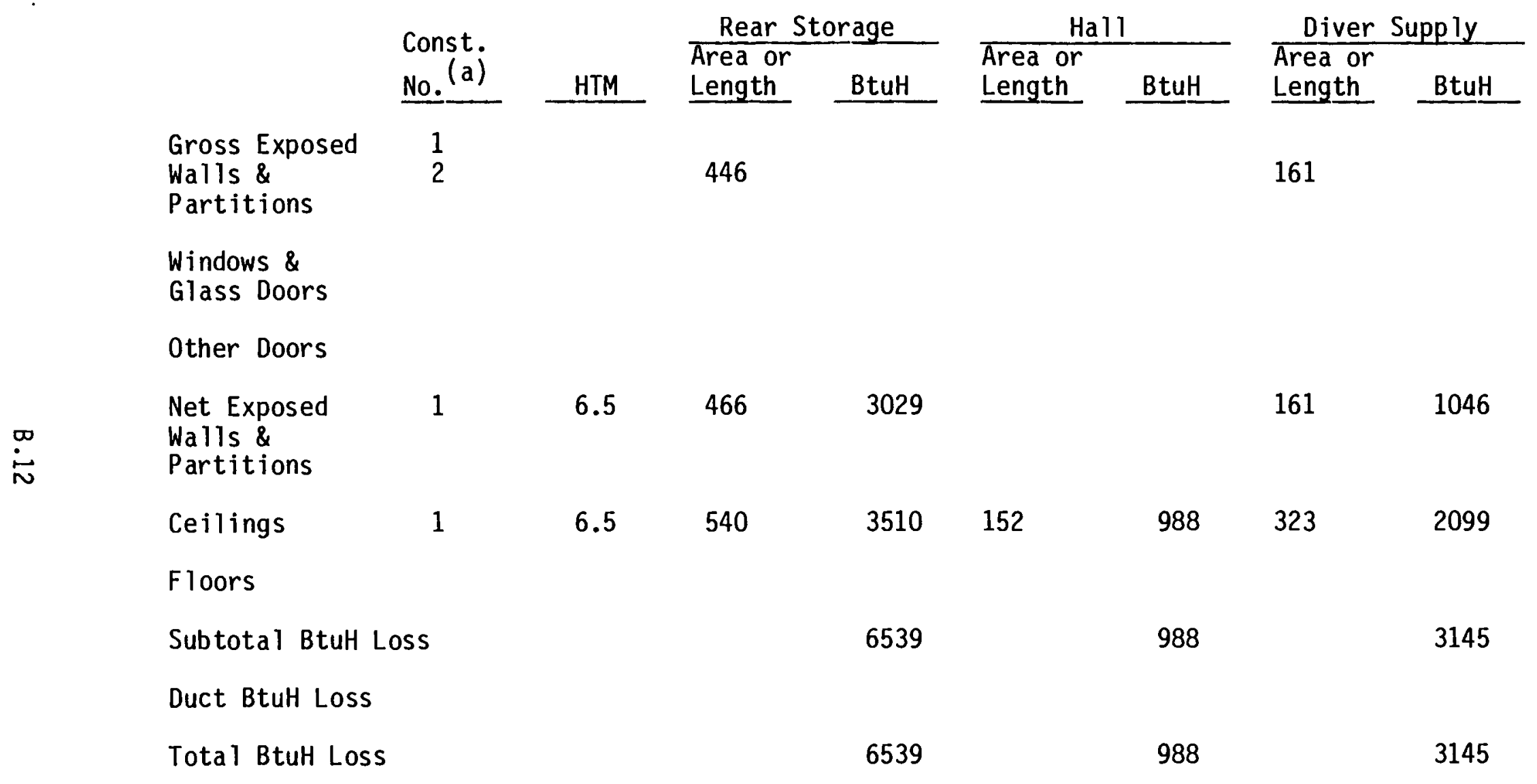

(a) From ACCA Manual J. Table 2 (ACCA 1975, p. 31-33). Heat Loss and Heat Gain Calculation Worksheet format from (ACCA 1975, p. 13). 
TABLE B.6. Heat Load Calculation Data for Warehouse

Ceiling - Butler F-103 1" wall system, $U=0.1$

Walls - Butler F-103 1" wall system $U=0.1$, except for builtup wall with $U=0.07$ " office, woodshop, machine shop, toilet room, and boiler room

Windows - (Letters refer to Figures 5.3 and 5.4)
(A) 4'-0" $\times 6^{\prime}-0 "$ Horizontal Spiding Aluminum
Frame Double Glazed
(B) 4'-0" $\times$ 7'-0" Fixed Aluminum Frame Double Glazed

Doors - (Numbers refer to Figures 5.3 and 5.4 )
(1) $3^{\prime}-0 " 1 \times 7^{\prime}-0 "$ Foam Core Steel Exterior Doors
(2) 16'-0" $\times 16^{\prime}-0 "$ Overhead Plywood Door
(3) 3'-0" $\times 7^{\prime}-0 "$ Foam Core Steel Exterior Doors
(4) 6'-0" $\times 7^{\prime}-0^{\prime \prime} \quad$ Foam Core Steel Exterior Doors

Floor - Concrete slab 
TABLE B.7. Summary of Design Heat Loads and Heating System for Snettisham Salmon Hatchery

Outdoor Design Temperature $=-20{ }^{\circ} \mathrm{F}$

\begin{tabular}{|c|c|c|c|c|}
\hline Room & $\begin{array}{l}\text { Interior } \\
\text { Design } \\
\text { Temp. } \\
\left({ }^{O} \mathrm{~F}\right) \\
\end{array}$ & $\begin{array}{l}\text { Design } \\
\text { Heat } \\
\text { Load } \\
\text { (Btu/hr) } \\
\end{array}$ & $\begin{array}{l}\text { Heating } \\
\text { Rating } \\
\text { ( } \mathrm{kW}) \\
\end{array}$ & $\begin{array}{c}\text { System Components } \\
\text { Type } \\
\end{array}$ \\
\hline Shop & 70 & 23,400 & 10 & Unit Heater \\
\hline Office/Hall & 70 & 20,860 & $\begin{array}{l}5 \\
2.5\end{array}$ & $\begin{array}{l}\text { Cabinet Unit Heater } \\
\text { Fin Pipe Heaters }(2)\end{array}$ \\
\hline Lab & 70 & 6,200 & 1.5 & Wa11 Heater \\
\hline Women & 70 & 760 & 1.5 & Wall Heater \\
\hline Men & 70 & 1,700 & 1.5 & Wall Heater \\
\hline Mech. \#2 & 70 & 4,600 & $\begin{array}{r}45 \\
4 \\
12 \\
6\end{array}$ & $\begin{array}{l}\text { Booster Coil } \\
\text { Booster Coil } \\
\text { Heat ing Coil } \\
\text { Hot Water Heater }\end{array}$ \\
\hline $\begin{array}{l}\text { Ventilation } \\
\text { Heat Load } \\
\text { (110 cfm) }\end{array}$ & & $\underline{11,433}$ & & \\
\hline Subtotal @ $70^{\circ}$ & & 68,953 & & \\
\hline Incubation & 45 & 106,700 & & \\
\hline Mech. \#1 & 45 & 2,080 & $\begin{array}{l}1.5 \\
1.5\end{array}$ & $\begin{array}{l}\text { Wall Heater } \\
\text { Hot Water Heater }\end{array}$ \\
\hline $\begin{array}{l}\text { Sttorage \& } \\
\text { Egg Sorting }\end{array}$ & 45 & 8,880 & $\begin{array}{l}5 \\
8\end{array}$ & $\begin{array}{l}\text { Unit Heater } \\
\text { Infrared Heaters (2) }\end{array}$ \\
\hline Egg Handling & 45 & 14,560 & $\begin{array}{l}5 \\
8\end{array}$ & $\begin{array}{l}\text { Unit Heater } \\
\text { Infrared Heaters (2) }\end{array}$ \\
\hline $\begin{array}{l}\text { Formalin } \\
\text { Storage }\end{array}$ & 45 & 2,940 & & \\
\hline Generator Room & 45 & & 10 & Unit Heater \\
\hline $\begin{array}{l}\text { Ventilation } \\
\text { Heat Load } \\
\text { ( } 315 \mathrm{cfm})\end{array}$ & & 23,634 & & \\
\hline Subtotal $945^{\circ}$ & & 158,794 & & \\
\hline TOTAL & & 227,747 & 128 & \\
\hline
\end{tabular}

Source: Discussions with Vern Akin, Mechanical Design Engineer, April 1980. 
APPENDIX C

DETAILED HEATING SYSTEM DESIGN INFORMATION 


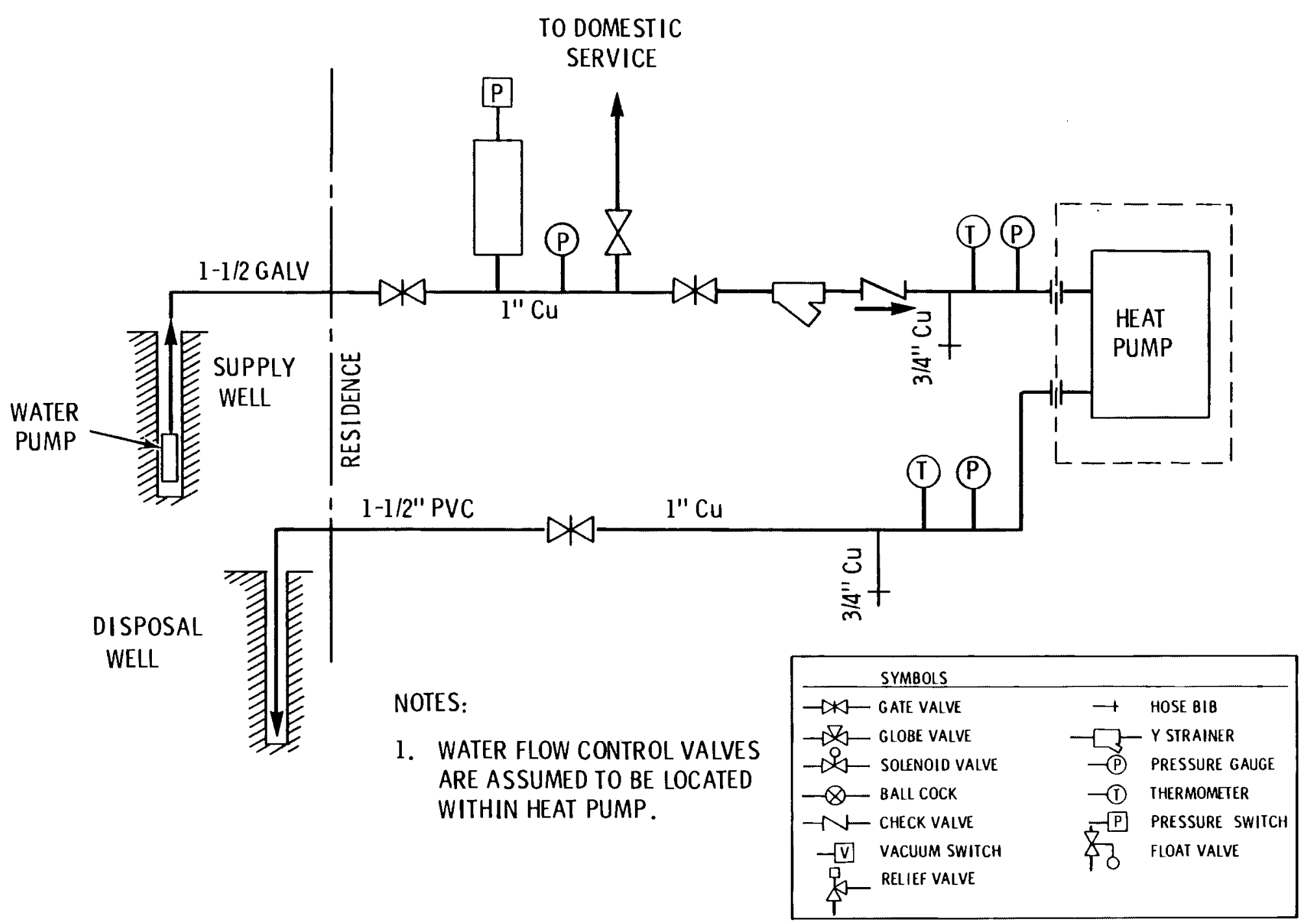

FIGURE C.1. Piping Design for Residence 


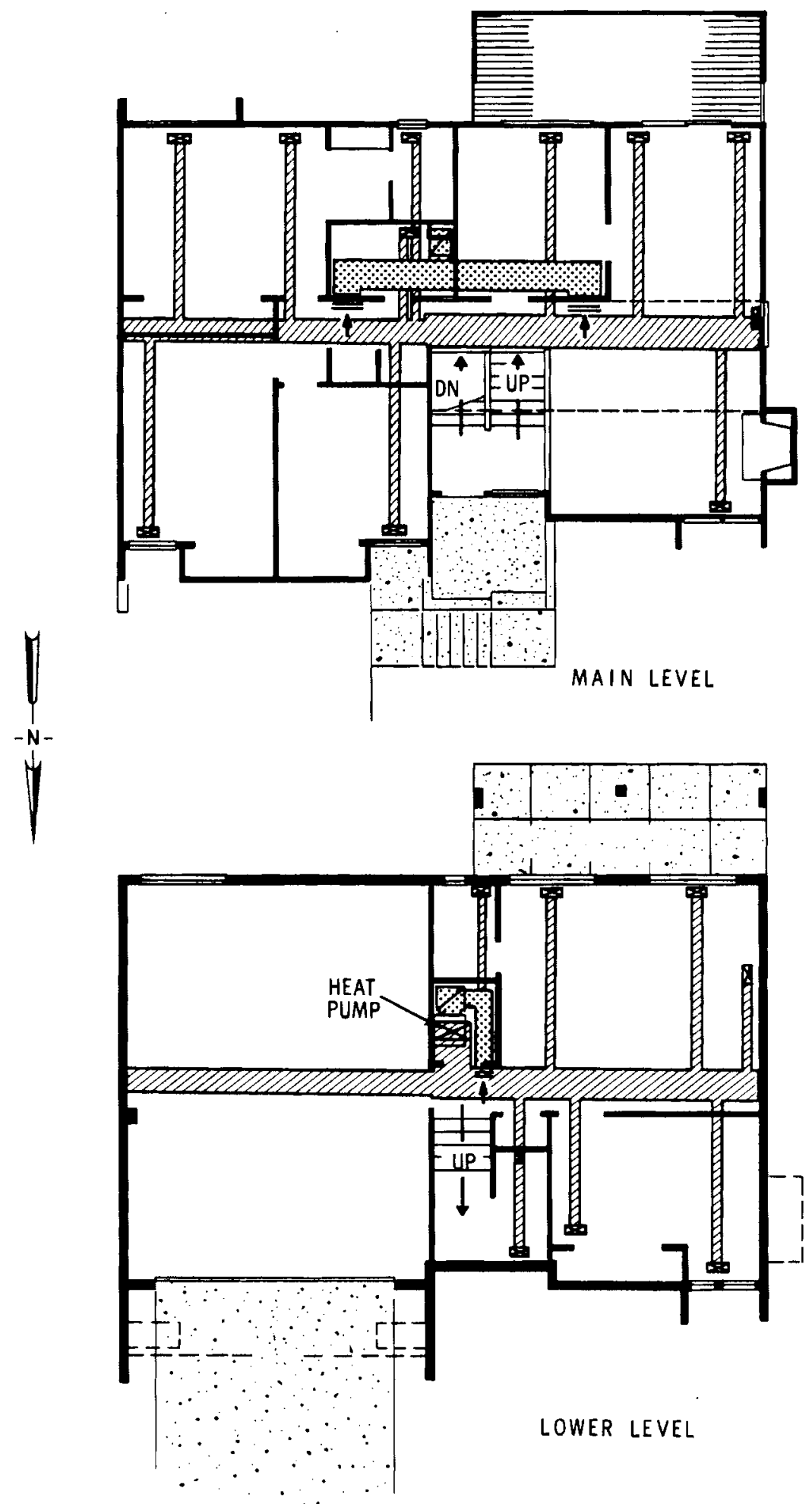

FIGURE C.2. Ductwork Design for Residence 


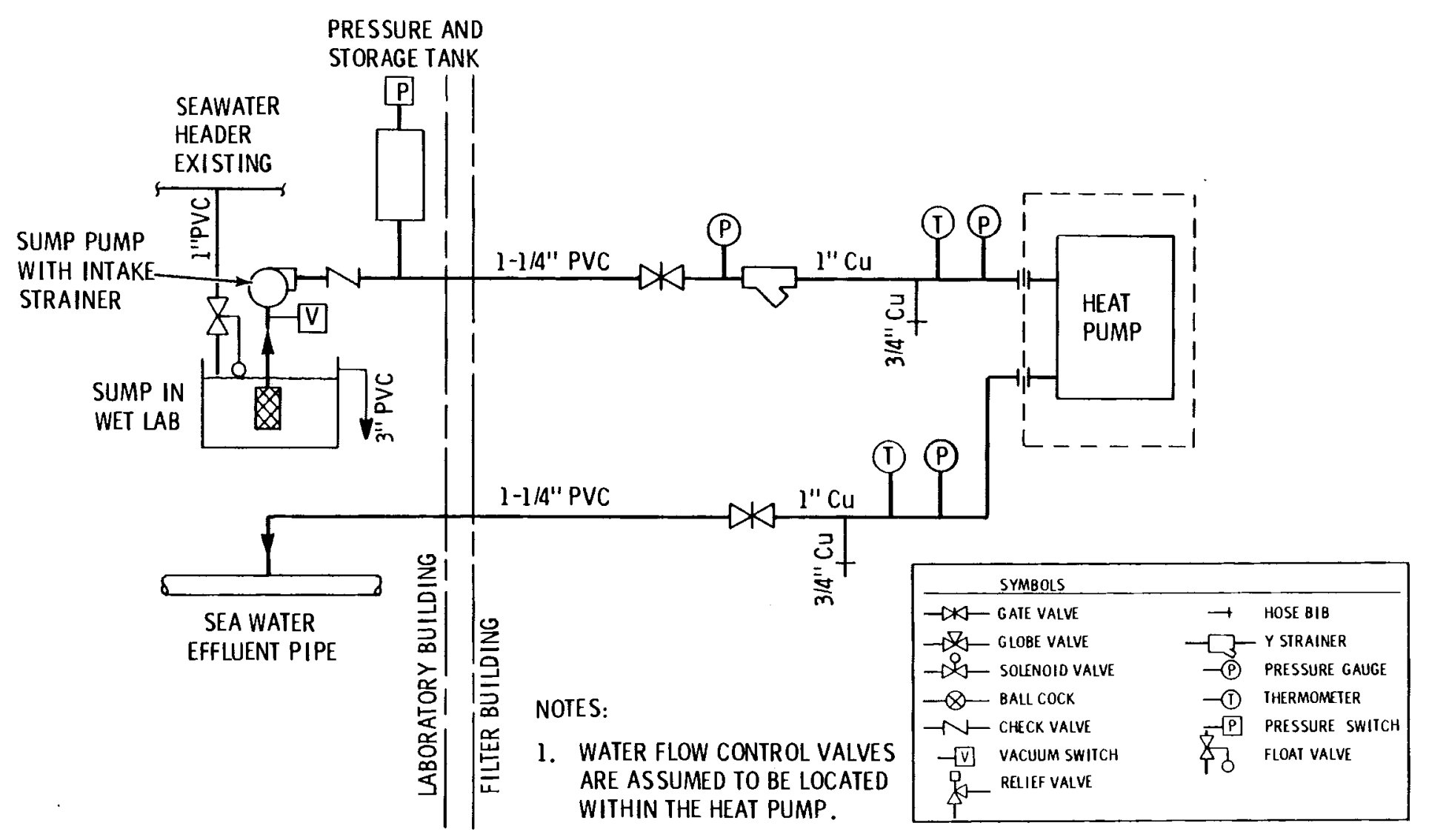

FIGURE C.3. Piping Design for Filter Building 


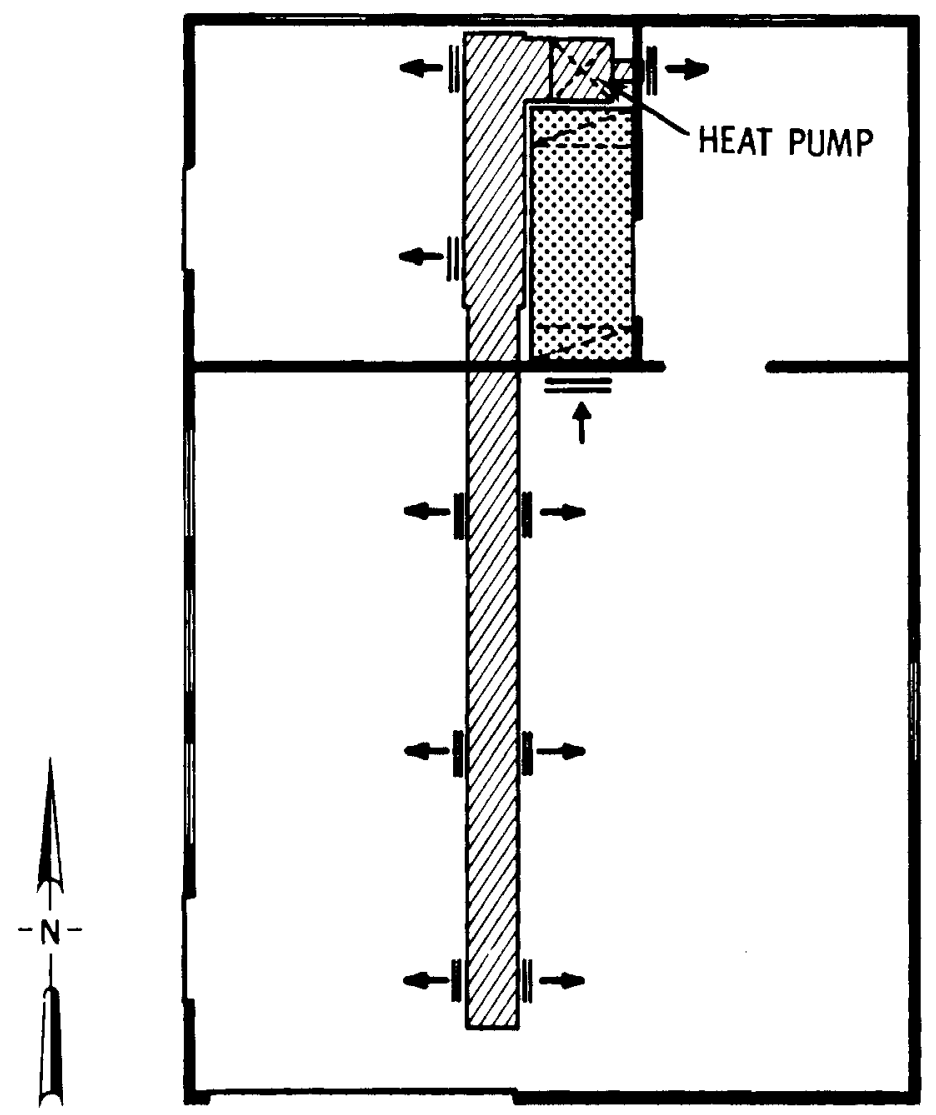

FIGURE C.4. Ductwork Design for Filter Building 


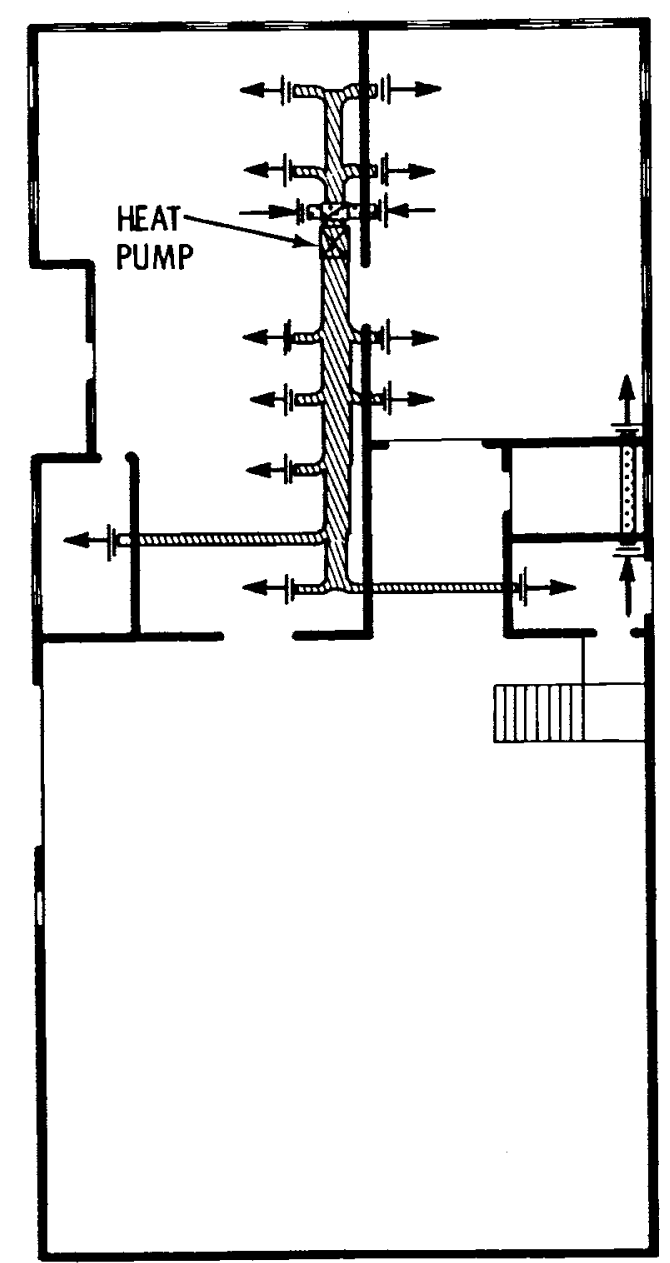

FIRST FLOOR

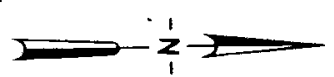

FIGURE C.5. Ductwork design for First Floor of Warehouse
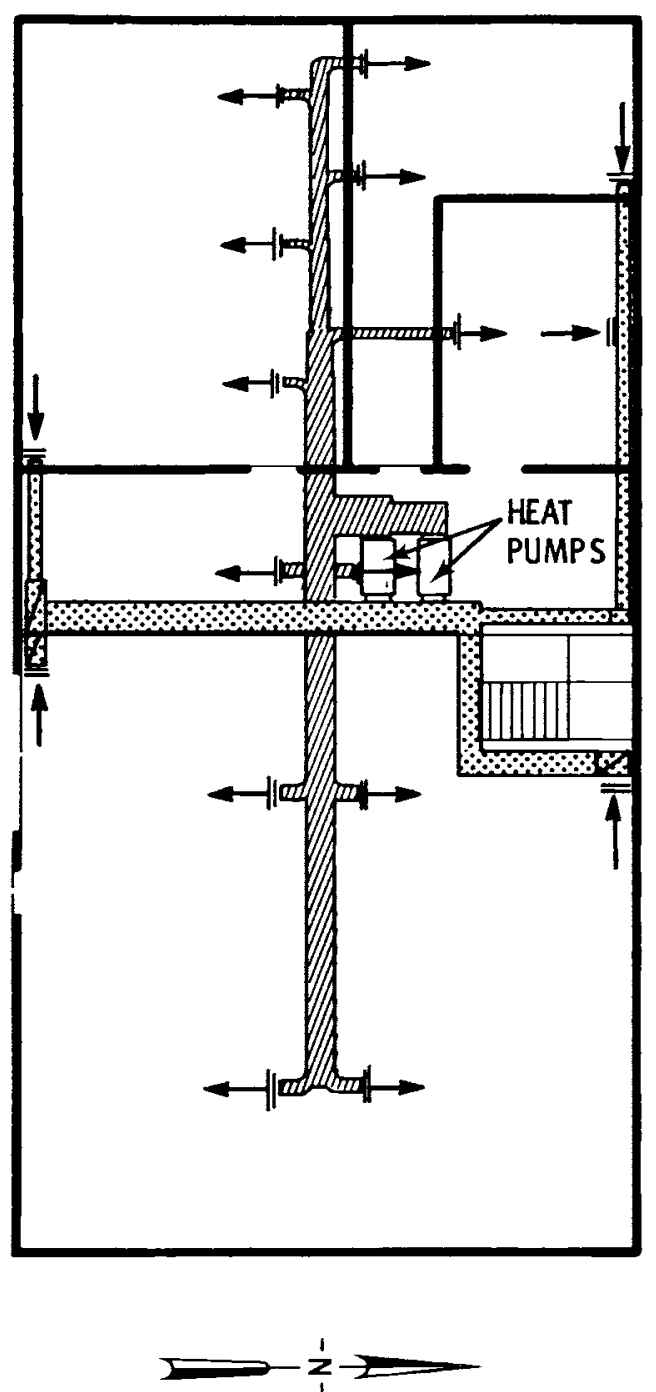

FIGURE C.6. Ductwork Design for Mezzanine of Warehouse 


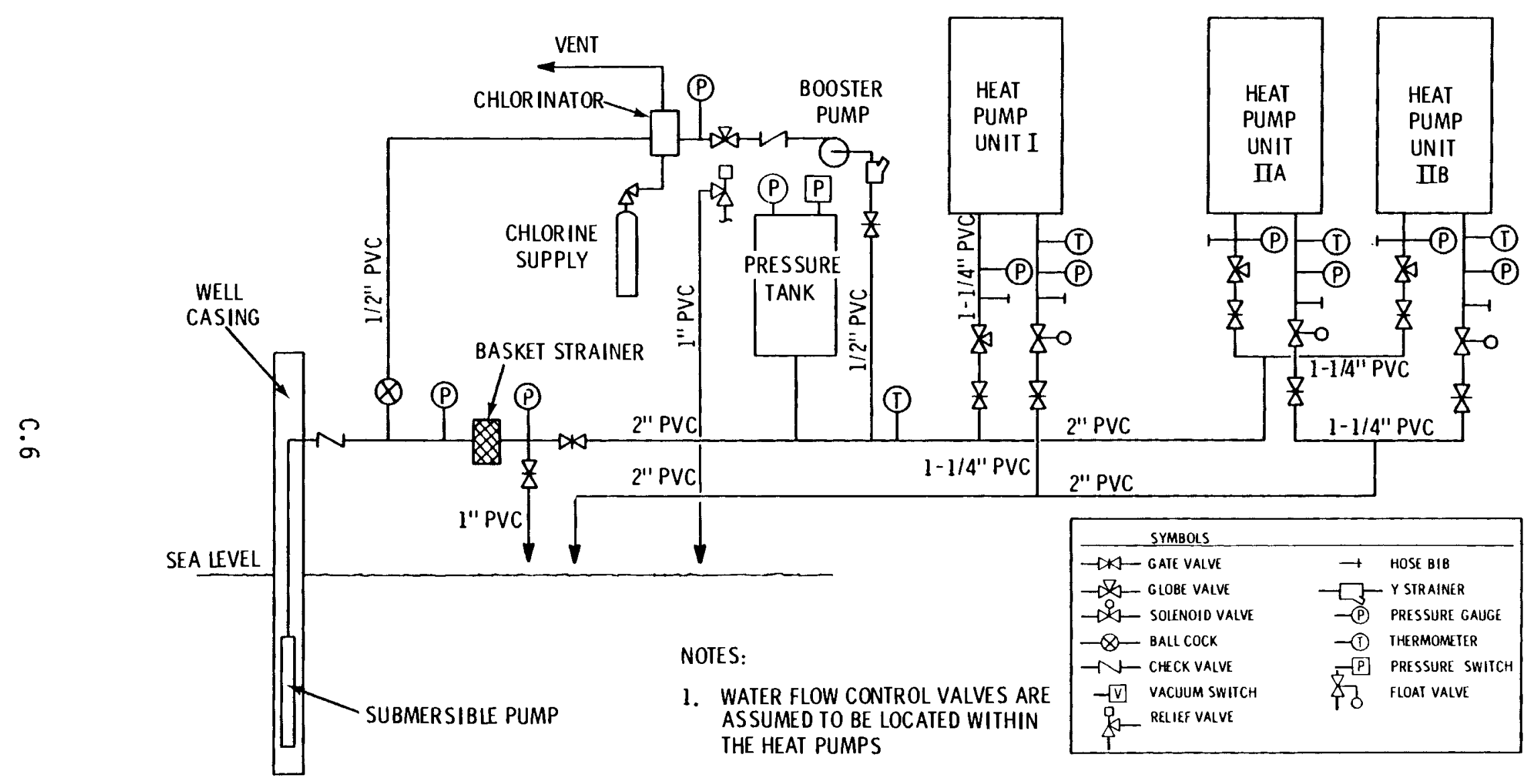

FIGURE C.7. Piping Design for Warehouse 
FROM INCUBATION

ROOM HEADBOX

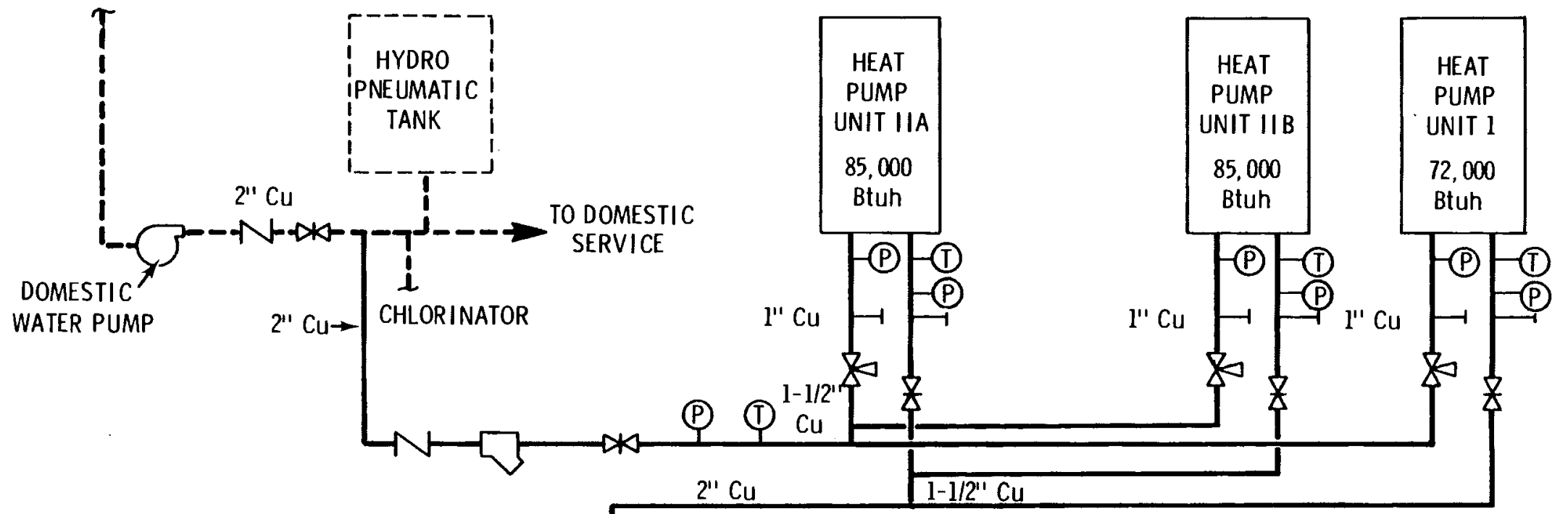

TO FLOOR DRAIN

\begin{tabular}{|c|c|}
\hline SYI & \\
\hline 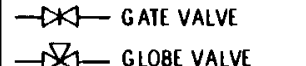 & $\rightarrow \quad$ HOSE BIB \\
\hline $\begin{array}{l}\text { D- GlOBE VALVE } \\
\square-\text { SOLENOID VALVE }\end{array}$ & r r SIRAINER \\
\hline-8 - BaLL COCK & -(i) THERMOMETER \\
\hline -N CHECK VALVE & Pres PRESURE SWITCH \\
\hline $\begin{array}{l}\text { - V VACUUM SWITCH } \\
\text { a RELIEF VALVE }\end{array}$ & FLOAT VALVE \\
\hline
\end{tabular}

FIGURE C.8. Piping Design for Salmon Hatchery 


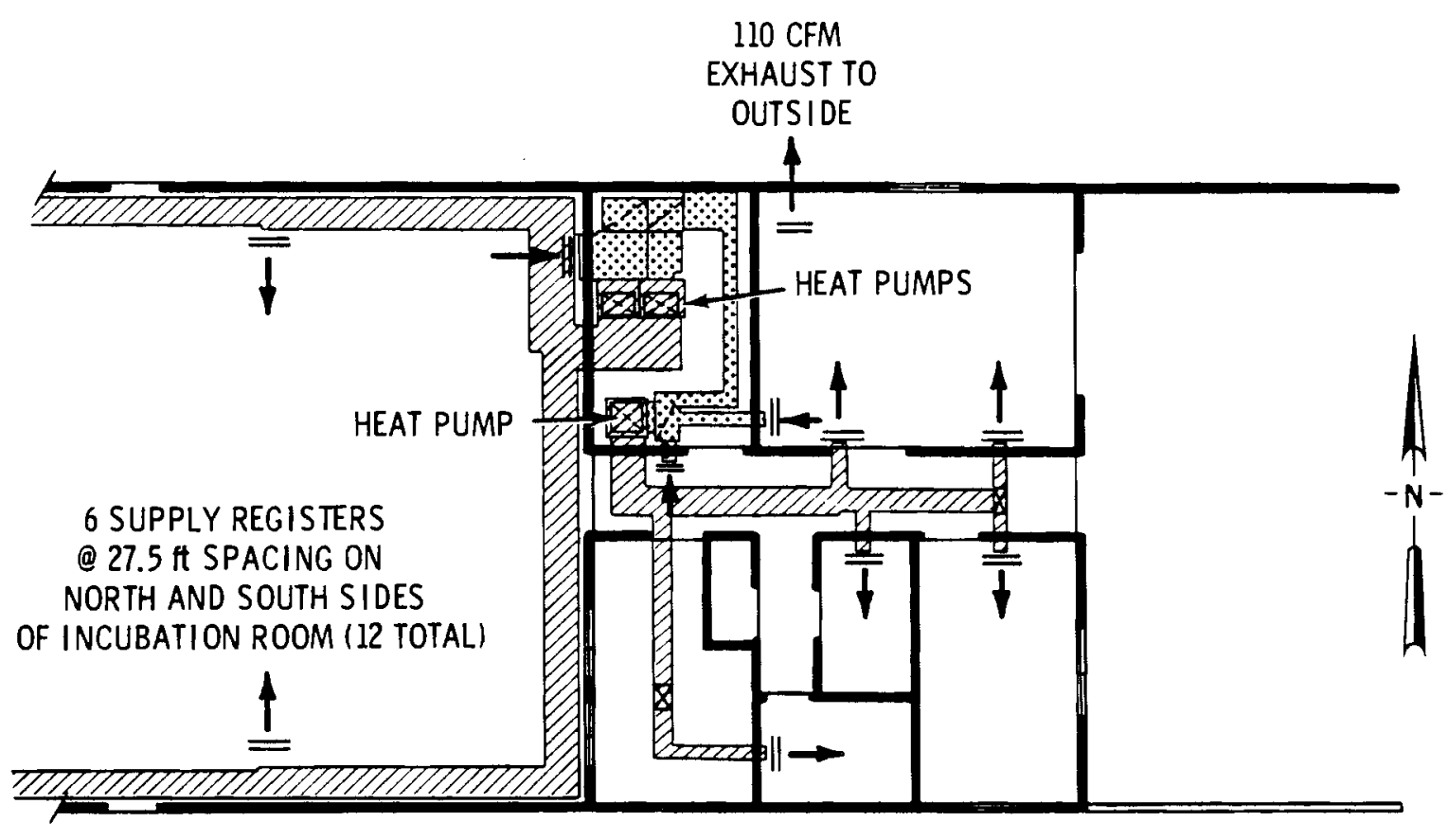

EAST END

FIGURE C.9. Ductwork Design for East End of Salmon Hatchery

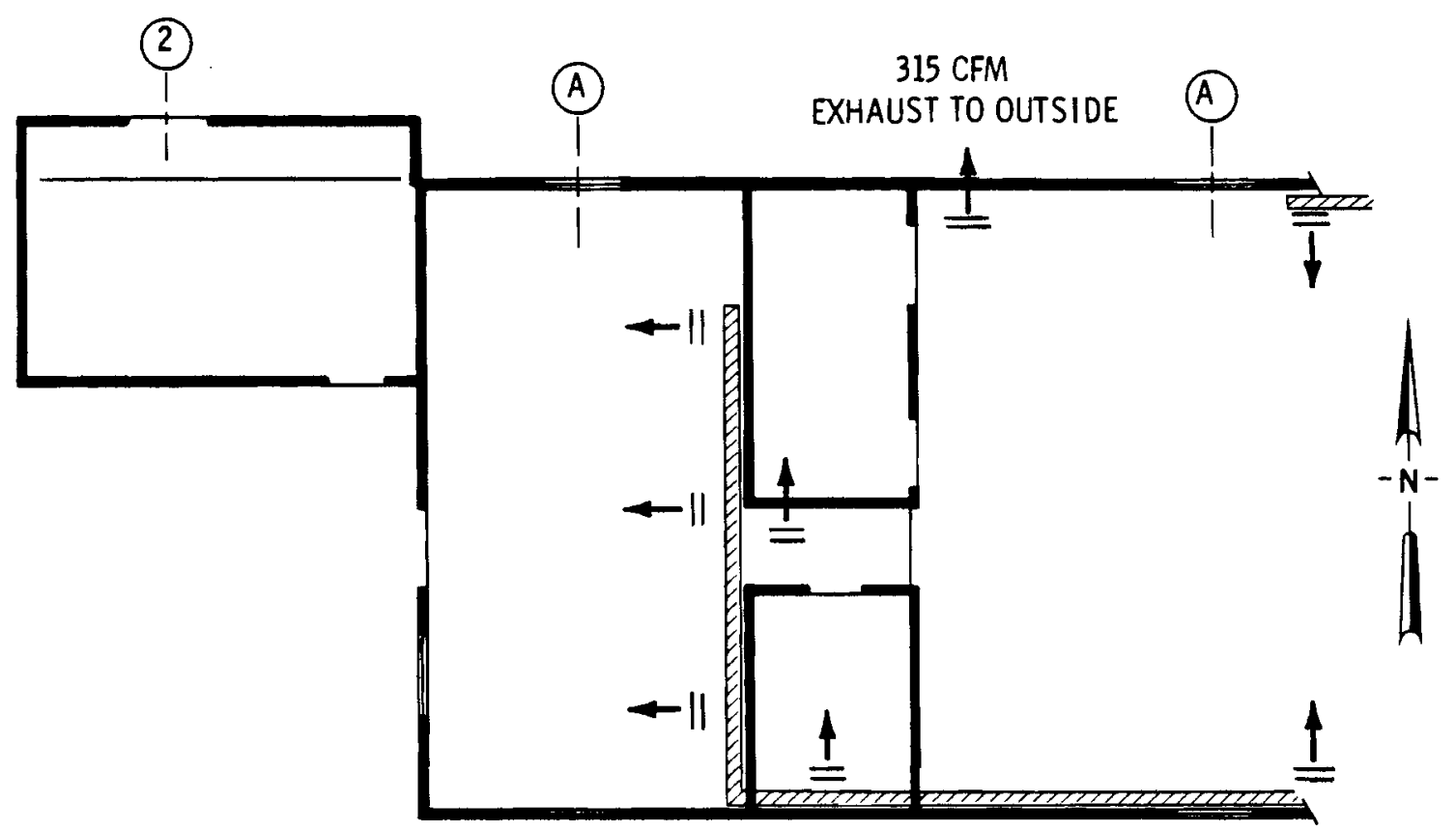

WEST END

FIGURE C.10. Ductwork Design for West End of Salmon Hatchery 
APPENDIX D

LIFE CYCLE COST CALCULATIONS. 
TABLE D.1. Annual Heating Requirements for Residence Case 1

\begin{tabular}{|c|c|c|c|}
\hline $\begin{array}{c}\text { Outdoor } \\
\text { Temperature } \\
\left({ }^{0} \mathrm{~F}\right) \\
\end{array}$ & $\begin{array}{l}\text { Hours / } \\
\text { Year }\end{array}$ & $\begin{array}{c}\text { Heat } \\
\text { Load } \\
\text { (Btu/hr) } \\
\end{array}$ & $\begin{array}{c}\text { Heating } \\
\text { Required } \\
(1000 \text { Btus) } \\
\end{array}$ \\
\hline 62 & 56 & 1,837 & 103 \\
\hline 57 & 100 & 4,900 & 490 \\
\hline 52 & 292 & 7,962 & 2,325 \\
\hline 47 & 649 & 11,025 & 7,155 \\
\hline 42 & 1,192 & 14,087 & 16,792 \\
\hline 37 & 1,207 & 17,150 & 20,700 \\
\hline 32 & 1,169 & 20,212 & 23,628 \\
\hline 27 & 1,446 & 23,275 & 33,656 \\
\hline 22 & 1,117 & 26,336 & 29,419 \\
\hline 17 & 545 & 29,400 & 16,023 \\
\hline 12 & 328 & 32,462 & 10,648 \\
\hline 7 & 200 & 35,525 & 7,105 \\
\hline 2 & 163 & 38,587 & 6,290 \\
\hline-3 & 119 & 41,650 & 4,956 \\
\hline-8 & 60 & 44,712 & 2,683 \\
\hline-13 & 29 & 47,775 & 1,385 \\
\hline-18 & 11 & $\underline{50,837}$ & 559 \\
\hline & 8,683 & -- & 183,917 \\
\hline
\end{tabular}

Source: See note, page D.6. 
TABLE D.2. Annual Heating Requirements for the Filter Building - Case 2

\begin{tabular}{c}
$\begin{array}{c}\text { Outdoor } \\
\text { Temperature } \\
\left({ }^{\mathrm{F}}\right)\end{array}$ \\
\hline 62 \\
57 \\
52 \\
47 \\
42 \\
37 \\
32 \\
27 \\
22 \\
17 \\
12 \\
7 \\
2 \\
-3 \\
-8 \\
-13 \\
-18
\end{tabular}

Total

$\begin{array}{r}\begin{array}{r}\text { Hours/ } \\ \text { Year }\end{array} \\ \hline 292 \\ 649 \\ 1,192 \\ 1,207 \\ 1,169 \\ 1,446 \\ 1,117 \\ 545 \\ 328 \\ 200 \\ 163 \\ 119 \\ 60 \\ 29 \\ 9 \\ 2 \\ 0 \\ \hline\end{array}$

$\frac{\begin{array}{c}\text { Heat } \\ \text { Load } \\ \text { Btu/hr) }\end{array}}{0}$

Heating

(1000 Btus)

0

0

0

3,397

9,173

7,600

14,437

12,350

24,726

17,100

24,406

21,850

14,497

26,600

10,282

31,350

7,220

6,658

5,426

3,021

1,598

538

129

64,600

0

$$
8,527
$$

$--$

125,508

Source: See note, page D.6. 
TABLE D.3. Annual Heating Requirements for the Warehouse Case 3

\begin{tabular}{|c|c|c|c|}
\hline $\begin{array}{c}\text { Outdoor } \\
\text { Temperature } \\
\left({ }^{\mathrm{O}} \mathrm{F}\right) \\
\end{array}$ & $\begin{array}{c}\text { Hours/ } \\
\text { Year } \\
\end{array}$ & $\begin{array}{c}\text { Heat } \\
\text { Load } \\
\text { (Btu/hr) } \\
\end{array}$ & $\begin{array}{r}\text { Heating } \\
\text { Required } \\
\text { (1000 Btus) }\end{array}$ \\
\hline 62 & 292 & 0 & 0 \\
\hline 57 & 649 & 0 & 0 \\
\hline 52 & 1,192 & 10,700 & 12,754 \\
\hline 47 & 1,207 & 28,533 & 34,439 \\
\hline 42 & 1,169 & 46,366 & 54,202 \\
\hline 37 & 1,446 & 64,200 & 92,833 \\
\hline 32 & 1,117 & 82,033 & 91,631 \\
\hline 27 & 545 & 99,866 & 54,427 \\
\hline 22 & 328 & 117,700 & 38,605 \\
\hline 17 & 200 & 135,533 & 27,106 \\
\hline 12 & 163 & 153,366 & 24,998 \\
\hline 7 & 119 & 171,200 & 20,372 \\
\hline 2 & 60 & 189,033 & 11,342 \\
\hline-3 & 29 & 206,866 & 6,000 \\
\hline-8 & 9 & 224,700 & 2,022 \\
\hline-13 & 2 & 242,533 & 485 \\
\hline-18 & $\underline{0}$ & $\underline{0}$ & 0 \\
\hline & 8,527 & -- & 471,216 \\
\hline
\end{tabular}

Source: See note, page D.6. 
TABLE D.4. Annual Heating Requirements for Snettisham Fish Hatchery - Case 4 (Portion of building with interior design temperature of $700 \mathrm{~F}$ )

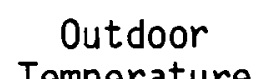

Temperature

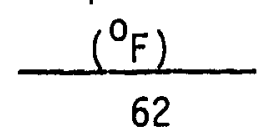

57

52

47

42

37

32

27

22

17

12

7

2

$-3$

$-8$

$-13$

$-18$

$-23$

$-28$

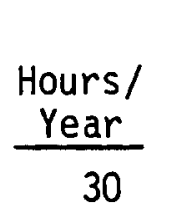

56

100

292

649

1,192

1,207

1,169

1,446

1,117

545

328

200

163

119

60

29

9

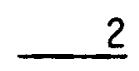

8,713

Tota 1

Source: See note, page D.6.

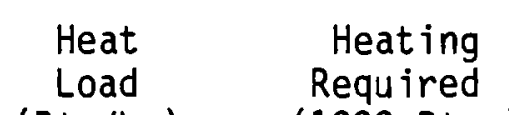

(Btu/hr) (1000 Btus)

2,435

6,494

73

363

10,552

1,055

14,611

4,266

18,670

12,116

22,729

27,092

32,333

36,060

50,472

43,522

23,447

15,442

10,228

8,997

7,051

3,799

1,953

642

150

$\underline{75,494}$

279,061 
TABLE D.5. Annual Heating Requirements for Snettisham Fish Hatchery - Case 4 (Portion of building with interior design temperature of $45^{\circ} \mathrm{F}$ )

\begin{tabular}{|c|c|c|c|}
\hline $\begin{array}{c}\text { Outdoor } \\
\text { Temperature } \\
\left({ }^{0} \mathrm{~F}\right) \\
\end{array}$ & $\begin{array}{c}\text { Hours/ } \\
\text { Year } \\
\end{array}$ & $\begin{array}{c}\text { Heat } \\
\text { Load } \\
\text { (Btu/hr) }\end{array}$ & $\begin{array}{c}\text { Heating } \\
\text { Requ ired } \\
\text { (1000 Btus) } \\
\end{array}$ \\
\hline 62 & 30 & 0 & 0 \\
\hline 57 & 56 & 0 & 0 \\
\hline 52 & 100 & 0 & 0 \\
\hline 47 & 292 & 0 & 0 \\
\hline 42 & 649 & 7,338 & 4,762 \\
\hline 37 & 1,192 & 19,569 & 23,326 \\
\hline 32 & 1,207 & 31,800 & 38,382 \\
\hline 27 & 1,169 & 44,030 & 51,471 \\
\hline 22 & 1,446 & 56,261 & 81,354 \\
\hline 17 & 1,117 & 68,492 & 76,505 \\
\hline 12 & 545 & 80,723 & 43,994 \\
\hline 7 & 328 & 92,953 & 30,488 \\
\hline 2 & 200 & 105,184 & 21,036 \\
\hline-3 & 163 & 117,415 & 19,138 \\
\hline-8 & 119 & 129,646 & 15,427 \\
\hline-13 & 60 & 141,876 & 8,512 \\
\hline-18 & 29 & 154,107 & 4,469 \\
\hline-23 & 9 & 166,338 & 1,497 \\
\hline-28 & 2 & 178,569 & 357 \\
\hline & 8,713 & -- & 420,718 \\
\hline
\end{tabular}

Source: See note, page D.6. 


\section{NOTES FOR TABLES D.1 THROUGH 0.5}

The shape of the annual temperature distribution used in the annual heating requirement calculations presented in Tables $D .1$ through 0.5 is from The Role of Electric Power in the Southeast Alaska Energy Economy, prepared by Applied Economics Associates, Inc. for the Alaska Power Administration, March 1979. The temperature data in that report is from Air Force Manual 88-8 and are averages for the Juneau airport over a 10-year period. The design load outdoor temperature for the Juneau airport is $-5^{\circ} \mathrm{F}$.

In the case of the Mendenhall Valley residence a $-15^{\circ} \mathrm{F}$ design temperature was suggested to be more representative of the local conditions by Juneau area heating contractors. The entire annual temperature distribution was reduced by $10^{\circ} \mathrm{F}$ for the Mendenhall Valley area. This temperature distribution is the same as is used in A Comparison of Home Heating Costs: Electricity Versus Oil, prepared by CH2M Hill for the Glacier Highway Electric Association, Auke Bay, Alaska, February 1980.

The Auke Bay area (the location of the filter building) was assumed to have a design load temperature and temperature distribution similar to the Juneau airport. The warehouse located at the NMFS subport facilities on the Juneau waterfront was also assumed to have a design load temperature and a temperature distribution similar to the Juneau airport. A $-20^{\circ} \mathrm{F}$ design load outdoor temperature was used for the design of the Snettisham salmon hatchery which is presently under construction. Since the temperature distribution for the Snettisham area was not available it was assumed that the shape of the temperature distribution at Snettisham was similar to the distribution at the Juneau airport. The entire temperature distribution was reduced by $15^{\circ} \mathrm{F}$. 
TABLE D.6. Life Cycle Cost Calculation for Direct Baseboard Electrical Resistance Heating for Residence in the Mendenhall Valley

\begin{tabular}{|c|c|c|c|c|c|c|}
\hline & $\begin{array}{l}\text { Electricity } \\
\text { Required } \\
(\mathrm{kWh})(\mathrm{a}) \\
\end{array}$ & $\begin{array}{l}\text { Electricity } \\
\text { Cost } \\
(\$ / \mathrm{kWh})^{(b)} \\
\end{array}$ & $\begin{array}{c}\text { Total } \\
\text { Electrical } \\
\text { Cost } \\
(\$) \\
\end{array}$ & $\begin{array}{c}\text { Annual } \\
0 \& M \\
\text { Cost } \\
(\$)^{(c)} \\
\end{array}$ & $\begin{array}{c}\text { Annual } \\
\text { Investment } \\
\text { Cost } \\
(\$)^{(d)} \\
\end{array}$ & $\begin{array}{c}\text { Total } \\
\text { Annual } \\
\text { Cost } \\
(\$) \\
\end{array}$ \\
\hline 1981 & 53875 & 0.0374 & 2014 & -- & 327 & 2341 \\
\hline 1982 & 53875 & 0.0389 & 2095 & -- & 327 & 2422 \\
\hline 1983 & 53875 & 0.0405 & 2181 & -- & 327 & 2508 \\
\hline 1984 & 53875 & 0.0421 & 2268 & -- & 327 & 2595 \\
\hline 1985 & 53875 & 0.0438 & 2359 & -- & 327 & 2686 \\
\hline 1986 & 53875 & 0.0550 & 2963 & -- & 327 & 3290 \\
\hline 1987 & 53875 & 0.0571 & 3076 & -- & 327 & 3403 \\
\hline 1988 & 53875 & 0.0594 & 3200 & -- & 327 & 3527 \\
\hline 1989 & 53875 & 0.0618 & 3329 & -- & 327 & 3656 \\
\hline 1990 & 53875 & 0.0643 & 3464 & 198 & 327 & 3989 \\
\hline
\end{tabular}

Present Worth $(08 \%)=\$ 19,606$

Levelized Cost (10 years $08 \%$ ) $=\$ 2921$

(a) Electrical resistance heating assumed to be $100 \%$ efficient.

(b) See Figure 1.2.

(c) Based on $\$ 46 / \mathrm{hr}$ wage rate (1980 price level).

(d) See Table 6.6. 
TABLE D.7. Life Cycle Cost Calculation for Fluid Filled Baseboard Electrical Resistance Heating for Residence in the Mendenhali Valiey

\begin{tabular}{|c|c|c|c|c|c|c|}
\hline & $\begin{array}{l}\text { Electricity } \\
\text { Required } \\
(\mathrm{kWh})(\mathrm{a}) \\
\end{array}$ & $\begin{array}{c}\text { Electricity } \\
\text { Cost } \\
(\$ / \mathrm{kWh})^{(\mathrm{b})}\end{array}$ & $\begin{array}{c}\text { Total } \\
\text { Electrical } \\
\text { Cost } \\
(\$) \\
\end{array}$ & $\begin{array}{c}\text { Annual } \\
0 \& M \\
\text { Cost } \\
(\$)^{(c)} \\
\end{array}$ & $\begin{array}{c}\text { Annual } \\
\text { Investment } \\
\text { Cost } \\
(\$)^{(d)} \\
\end{array}$ & $\begin{array}{c}\text { Total } \\
\text { Annual } \\
\text { Cost } \\
(\$) \\
\end{array}$ \\
\hline 1981 & 53875 & 0.0374 & 2014 & -- & 405 & 2419 \\
\hline 1982 & 53875 & 0.0389 & 2095 & -- & 405 & 2500 \\
\hline 1983 & 53875 & 0.0405 & 2181 & - & 405 & 2586 \\
\hline 1984 & 53875 & 0.0421 & 2268 & -- & 405 & 2673 \\
\hline 1985 & 53875 & 0.0438 & 2359 & -- & 405 & 2764 \\
\hline 1986 & 53875 & 0.0550 & 2963 & -- & 405 & 3368 \\
\hline 1987 & 53875 & 0.0571 & 3076 & -- & 405 & 3481 \\
\hline 1988 & 53875 & 0.0594 & 3200 & -- & 405 & 3605 \\
\hline 1989 & 53875 & 0.0618 & 3329 & -- & 405 & 3734 \\
\hline 1990 & 53875 & 0.0643 & 3464 & 198 & 405 & 4067 \\
\hline
\end{tabular}

Present Worth (@ 8\%) $=\$ 20,129$

Leve iized Cost (10 years $08 \%)=\$ 2999$

(a) Electrical resistance heating assumed to be $100 \%$ efficient.

(b) See Figure 1.2.

(c) Based on $\$ 46 / \mathrm{hr}$ wage rate (1980 price level).

(d) See Table 6.6. 
TABLE 0.8. Life Cycle Cost Calculation for 0il-Hydronic Heating for Residence in the Mendenhall Valley

\begin{tabular}{|c|c|c|c|c|c|c|}
\hline & $\begin{array}{c}\text { Fuel } 0 i 1 \\
\text { Required } \\
\text { (Gallons) } \\
\end{array}$ & $\begin{array}{c}\text { Fuel oil } \\
\text { Cost } \\
(\$ / \text { gallon })^{(b)} \\
\end{array}$ & $\begin{array}{l}\text { Total } \\
\text { Fuel } 0 i 1 \\
\text { Cost } \\
(\$) \\
\end{array}$ & $\begin{array}{c}\text { Annual } \\
\text { O\&M } \\
\text { Cost } \\
(\$)^{(c)} \\
\end{array}$ & $\begin{array}{c}\text { Annual } \\
\text { Investment } \\
\text { Cost } \\
(\$)^{(d)} \\
\end{array}$ & $\begin{array}{c}\text { Total } \\
\text { Annual } \\
\text { Cost } \\
(\$) \\
\end{array}$ \\
\hline 1981 & 2412 & 1.03 & 2484 & 75 & 475 & 3034 \\
\hline 1982 & 2412 & 1.15 & 2774 & 81 & 475 & 3330 \\
\hline 1983 & 2412 & 1.27 & 3063 & 87 & 475 & 3625 \\
\hline 1984 & 2412 & 1.41 & 3401 & 94 & 475 & 3970 \\
\hline 1985 & 2412 & 1.57 & 3787 & 204 & 475 & 4466 \\
\hline 1986 & 2412 & 1.74 & 4187 & 109 & 475 & 4771 \\
\hline 1987 & 2412 & 1.93 & 4655 & 118 & 475 & 5248 \\
\hline 988 & 2412 & 2.14 & 5162 & 127 & 475 & 5764 \\
\hline 89 & 2412 & 2.38 & 5741 & 138 & 475 & 6354 \\
\hline 90 & 2412 & 2.64 & 6368 & 297 & 475 & 7140 \\
\hline
\end{tabular}

Present Worth (@ 8\%) $=\$ 30,164$

Levelized Cost (10 years $08 \%$ ) $=\$ 4495$

(a) $0 i 1$-hydronic home heating assumed to be $55 \%$ efficient. Fuel oil heating value assumed to be $138,690 \mathrm{Btu} / \mathrm{gall}$ on.

(b) See Figure 1.1.

(c) Based on $\$ 46 / \mathrm{hr}$ wage rate (1980 price level).

(d) See Table 6.6. 
TABLE D.9. Life Cycle Cost Calculation for Air to Air Heat Pump for Residence in the Mendenhall Valley

\begin{tabular}{|c|c|c|c|c|c|c|}
\hline & $\begin{array}{l}\text { Electricity } \\
\text { Required } \\
(\mathrm{kWh})^{(\mathrm{a})} \\
\end{array}$ & $\begin{array}{l}\text { Electricity } \\
\text { Cost } \\
(\$ / \mathrm{kWh})^{(\mathrm{b})} \\
\end{array}$ & $\begin{array}{c}\text { Total } \\
\text { Electrical } \\
\text { Cost } \\
(\$) \\
\end{array}$ & $\begin{array}{c}\text { Annual } \\
0 \& M \\
\text { Cost } \\
(\$)^{(c)} \\
\end{array}$ & $\begin{array}{c}\text { Annual } \\
\text { Investment } \\
\text { Cost } \\
(\$)(d) \\
\end{array}$ & $\begin{array}{c}\text { Total } \\
\text { Annual } \\
\text { Cost } \\
(\$)\end{array}$ \\
\hline 1981 & 28114 & 0.0374 & 1051 & -- & 882 & 1933 \\
\hline 1982 & 28114 & 0.0389 & 1093 & 108 & 882 & 2083 \\
\hline 1983 & 28114 & 0.0405 & 1138 & -- & 882 & 2020 \\
\hline 1984 & 28114 & 0.0421 & 1183 & -- & 882 & 2065 \\
\hline 1985 & 28114 & 0.0438 & 1231 & 272 & 882 & 2385 \\
\hline 1986 & 28114 & 0.0550 & 1546 & -- & 882 & 2428 \\
\hline 1987 & 28114 & 0.0571 & 1605 & 158 & 882 & 2645 \\
\hline 1988 & 28114 & 0.0594 & 1669 & -- & 882 & 2551 \\
\hline 1989 & 28114 & 0.0618 & 1737 & -- & 882 & 2619 \\
\hline 1990 & 28114 & 0.0643 & 1807 & 396 & 882 & 2689 \\
\hline
\end{tabular}

Present Worth (@ 8\%) $=\$ 15,323$

Levelized Cost $(10$ years $08 \%)=\$ 2283$

(a) Annual electricity required is derived from case for air to air heat pump heating in CH2M (1980), Appendix Table 6 . Annual electricity required is assumed to be proportional to total heating requirement.

$240,223 \mathrm{KBtu}$ [heating required from CH2M (1980)] 184,000 KBtu (heating calculated for residence)

$=\frac{36,722 \mathrm{kWh} \text { [annual energy consumption from CH2M (1980)] }}{28,114 \mathrm{kWh} \text { (derived annual energy consumption for residence) }}$

This is equivalent to a seasonal system COP of 1.92 which is the same as CH2M (1980), Appendix Table 6.

(b) See Figure 1.2.

(c) Based on $\$ 46 / \mathrm{hr}$ wage rate (1980 price leve 1).

(d) See Table 6.6. 
TABLE D.10. Life Cycle Cost Calculation for Water Source Heat Pump Heating for Residence in the Mendenhall Valley

\begin{tabular}{|c|c|c|c|c|c|c|}
\hline & $\begin{array}{c}\text { Electricity } \\
\text { Required } \\
(\mathrm{kWh})^{(\mathrm{a})} \\
\end{array}$ & $\begin{array}{l}\text { Electricity } \\
\text { Cost } \\
(\$ / k W h)^{(b)} \\
\end{array}$ & $\begin{array}{c}\text { Total } \\
\text { Electrical } \\
\text { Cost } \\
(\$) \\
\end{array}$ & $\begin{array}{l}\text { Annual } \\
0 \& M \\
\text { Cost } \\
(\$)^{(c)} \\
\end{array}$ & $\begin{array}{c}\text { Annual } \\
\text { Investment } \\
\text { Cost } \\
(\$)(d) \\
\end{array}$ & $\begin{array}{l}\text { Total } \\
\text { Annual } \\
\text { Cost } \\
(\$) \\
\end{array}$ \\
\hline 1981 & 23949 & 0.0374 & 895 & -- & 1864 & 2759 \\
\hline 1982 & 23949 & 0.0389 & 931 & 108 & 1864 & 2903 \\
\hline 1983 & 23949 & 0.0405 & 969 & -- & 1864 & 2833 \\
\hline 1984 & 23949 & 0.0421 & 1008 & -- & 1864 & 2872 \\
\hline 1985 & 23949 & 0.0438 & 1048 & 272 & 1864 & 3184 \\
\hline 1986 & 23949 & 0.0550 & 1317 & -- & 1864 & 3181 \\
\hline 1987 & 23949 & 0.0571 & 1367 & 158 & 1864 & 3389 \\
\hline 1988 & 23949 & 0.0594 & 1422 & -- & 1864 & 3286 \\
\hline 1989 & 23949 & 0.0618 & 1480 & -- & 1864 & 3344 \\
\hline 1990 & 23949 & 0.0643 & 1539 & 396 & 1864 & 3799 \\
\hline
\end{tabular}

Present Worth (@ 8\%) $=\$ 20,751$

Levelized Cost (10 years o 8\%) $=\$ 3092$

(a) Seasonal system COPs for WSHPs vary depending upon the design of specific units and the blower and pumping allowance included. A seasonal system COP of 2.25 is used in this cost comparison. This includes both blower and pump allowances. The pump allowance is based upon $160 \mathrm{ft}$ total head and a $30 \%$ wire-to-water efficiency.

(b) See Figure 1.2 .

(c) Based on $\$ 46 / \mathrm{hr}$ wage rate (1980 price leve1).

(d) See Table 6.5. 
TABLE D.11. Life Cycle Cost Calculation for Forced Air $0 i 1$ Heating for Filter Building

\begin{tabular}{|c|c|c|c|c|c|c|}
\hline & $\begin{array}{c}\text { Fuel } 0 \text { il } \\
\text { Required } \\
\text { (Gallons) }^{(a)} \\
\end{array}$ & $\begin{array}{c}\text { Fuel } 0 i 1 \\
\text { Cost } \\
\text { (\$/gallon) (b) }\end{array}$ & $\begin{array}{c}\text { Total } \\
\text { Fue } 10 i 1 \\
\text { Cost } \\
(\$) \\
\end{array}$ & $\begin{array}{l}\text { Annual } \\
0 \& M \\
\text { Cost } \\
(\$)^{(c)} \\
\end{array}$ & $\begin{array}{c}\text { Annual } \\
\text { Investment } \\
\text { Cost } \\
(\$)^{(d)} \\
\end{array}$ & $\begin{array}{c}\text { Total } \\
\text { Annual } \\
\text { Cost } \\
(\$) \\
\end{array}$ \\
\hline 1981 & 1645 & 1.03 & 1694 & 75 & 428 & 2197 \\
\hline 1982 & 1645 & 1.15 & 1891 & 81 & 428 & 2400 \\
\hline 1983 & 1645 & 1.27 & 2089 & 87 & 428 & 2604 \\
\hline 1984 & 1645 & 1.41 & 2319 & 94 & 428 & 2841 \\
\hline 1985 & 1645 & 1.57 & 2582 & 204 & 428 & 3214 \\
\hline 1986 & 1645 & 1.74 & 2862 & 109 & 428 & 3399 \\
\hline 1987 & 1645 & 1.93 & 3174 & 118 & 428 & 3720 \\
\hline 1988 & 1645 & 2.14 & 3520 & 127 & 428 & 4075 \\
\hline 1989 & 1645 & 2.38 & 3915 & 138 & 428 & 4481 \\
\hline 1990 & 1645 & 2.64 & 4342 & 297 & 428 & 5067 \\
\hline
\end{tabular}

Present Worth (0 8\%) $=\$ 21,532$

Levelized Cost (10 years $08 \%$ ) $=\$ 3208$

(a) Computed fue 1 oil requirements assuming a 55\% heating efficiency and $138,690 \mathrm{Btu} / \mathrm{gall}$ on is $1645 \mathrm{gallons} /$ year. Actual consumption for year 1977 was 1258 gallons, for 1978 was 1344 gallons, and for 1979 was 2044 gallons (data supplied by NMFS, March 17, 1980). This gives a 3 -year average of 1548 gallons/year. In order to maintain consistency between the alternatives the computed value is used in Table D.5.

(b) See Figure 1.1.

(c) Based on $\$ 46 / \mathrm{hr}$ wage rate (1980 price level).

(d) See Table 6.8. 
TABLE D.12. Life Cycle Cost Calculation for Water Source Heat Pump Heating for Filter Building

\begin{tabular}{|c|c|c|c|c|c|c|}
\hline & $\begin{array}{l}\text { Electricity } \\
\text { Required } \\
(\mathrm{kWh})(\mathrm{a}) \\
\end{array}$ & $\begin{array}{l}\text { Electricity } \\
\text { Cost } \\
(\$ / \mathrm{kWh}) \\
(\mathrm{b})\end{array}$ & $\begin{array}{c}\text { Total } \\
\text { Electrical } \\
\text { Cost } \\
(\$) \\
\end{array}$ & $\begin{array}{c}\text { Annual } \\
\text { 0\&M } \\
\text { Cost } \\
(\$)^{(c)} \\
\end{array}$ & $\begin{array}{c}\text { Annual } \\
\text { Investment } \\
\text { Cost } \\
(\$)^{(d)} \\
\end{array}$ & $\begin{array}{c}\text { Total } \\
\text { Annual } \\
\text { Cost } \\
(\$) \\
\end{array}$ \\
\hline 1981 & 15195 & 0.0489 & 743 & -- & 2240 & 2983 \\
\hline 1982 & 15195 & 0.0508 & 771 & 108 & 2240 & 3119 \\
\hline 1983 & 15195 & 0.0529 & 803 & -- & 2240 & 3043 \\
\hline 1984 & 15195 & 0.0550 & 835 & -- & 2240 & 3075 \\
\hline 1985 & 15195 & 0.0572 & 869 & 272 & 2240 & 3381 \\
\hline 1986 & 15195 & 0.0690 & 1048 & -- & 2240 & 3288 \\
\hline 1987 & 15195 & 0.0717 & 1089 & 158 & 2240 & 3487 \\
\hline 1988 & 15195 & 0.0746 & 1133 & -- & 2240 & 3373 \\
\hline 1989 & 15195 & 0.0776 & 1179 & -- & 2240 & 3419 \\
\hline 1990 & 15195 & 0.0807 & 1226 & 396 & 2240 & 3862 \\
\hline
\end{tabular}

Present Worth $(08 \%)=\$ 21,838$

Levelized Cost (10 years \& $8 \%$ ) $=\$ 3254$

(a) Seasonal system COPS for WSHPs vary depending upon the design of specific units and the blower and pumping allowances included. A seasonal system COP of 2.40 is used here. This includes both blower and pump allowances. The pump allowance is based upon $140 \mathrm{ft}$ total head and a $30 \%$ wire-to-water efficiency.

(b) See Figure 1.2.

(c) Based on $\$ 46 / \mathrm{hr}$ wage rate (1980 price level).

(d) See Table 6.8. 
TABLE D.13. Life Cycle Cost Calculation for 0il-Hydronic Heating for Warehouse

\begin{tabular}{|c|c|c|c|c|c|c|}
\hline & $\begin{array}{c}\text { Fuel 0il } \\
\text { Required } \\
\text { (Gallons) }^{(a)} \\
\end{array}$ & $\begin{array}{c}\text { Fuel } 0 i 1 \\
\text { Cost } \\
\text { (\$/gallon) (b) }\end{array}$ & $\begin{array}{l}\text { Total } \\
\text { Fuel } 0 i 1 \\
\text { Cost } \\
(\$) \\
\end{array}$ & $\begin{array}{c}\text { Annual } \\
0 \& M \\
\text { Cost } \\
(\$)^{(c)} \\
\end{array}$ & $\begin{array}{c}\text { Annual } \\
\text { Investment } \\
\text { Cost } \\
(\$)^{(d)} \\
\end{array}$ & $\begin{array}{c}\text { Total } \\
\text { Annual } \\
\text { Cost } \\
(\$) \\
\end{array}$ \\
\hline 1981 & 4853 & 0.97 & 4707 & 150 & 3565 & 8422 \\
\hline 1982 & 4853 & 1.07 & 5192 & 162 & 3565 & 8919 \\
\hline 1983 & 4853 & 1.19 & 5775 & 174 & 3565 & 9514 \\
\hline 1984 & 4853 & 1.32 & 6405 & 189 & 3565 & 10159 \\
\hline 1985 & 4853 & 1.47 & 7133 & 408 & 3565 & 11106 \\
\hline 1986 & 4853 & 1.63 & 7910 & 219 & 3565 & 11694 \\
\hline 1987 & 4853 & 1.81 & 8783 & 237 & 3565 & 12585 \\
\hline 1988 & 4853 & 2.00 & 9706 & 255 & 3565 & 13526 \\
\hline 1989 & 4853 & 2.23 & 10822 & 276 & 3565 & 14663 \\
\hline 1990 & 4853 & 2.47 & 11986 & 594 & 3565 & 16145 \\
\hline
\end{tabular}

Present Worth (@ 8\%) $=\$ 74,853$

Levelized Cost $(10$ years $88 \%)=\$ 11,155$

(a) Computed fuel 0 il requirements assuming a 70\% heating efficiency and $138,690 \mathrm{Btu} / \mathrm{gall}$ ion is 4853 gallons. Actual consumption for year 1975 was 2978 gallons, for 1976 was 3786 gallons, for 1977 was 3291, for 1978 was 3681, and for 1979 was 5023 gallons (data supplied by NMFS, April 17, 1980). This gives a 5-year average of 3751 gallons/year. The difference between actual and computed oil consumption could be attributed to a number of factors such as the building being better insulated than assumed, design conditions being less severe than assumed, heating efficiency of furnace higher than assumed, more natural heat gain than assumed (none was assumed), etc. In order to maintain air consistency between the alternatives the computed value is used in Table D.7.

(b) 1980 price for fuel oil in 1500 gallon quantities was about $\$ 0.87$ (NMFS data, April 17, 1980). The price is assumed to escalate at $11 \%$ year.

(c) Based on $\$ 46 / \mathrm{hr}$ wage rate (1980 price levels).

(d) See Table 6.11. 
TABLE 0.14. Life Cycle Cost Calculation for Water Source Heat Pump Heating for the Warehouse

\begin{tabular}{|c|c|c|c|c|c|c|}
\hline & $\begin{array}{l}\text { Electricity } \\
\text { Required } \\
(\mathrm{kWh})^{(\mathrm{a})} \\
\end{array}$ & $\begin{array}{c}\text { Electricity } \\
\text { Cost } \\
(\$ / \mathrm{kWh})^{(\mathrm{b})}\end{array}$ & $\begin{array}{c}\text { Total } \\
\text { Electrical } \\
\text { Cost } \\
(\$) \\
\end{array}$ & $\begin{array}{c}\text { Annual } \\
0 \& M \\
\text { Cost } \\
(\$)^{(c)} \\
\end{array}$ & $\begin{array}{c}\text { Annual } \\
\text { Investment } \\
\text { Cost } \\
(\$)^{(d)} \\
\end{array}$ & $\begin{array}{l}\text { Total } \\
\text { Annual } \\
\text { Cost } \\
(\$) \\
\end{array}$ \\
\hline 1981 & 60028 & 0.0374 & 2245 & 415 & 10117 & 12777 \\
\hline 1982 & 60028 & 0.0389 & 2335 & 759 & 10117 & 13211 \\
\hline 1983 & 60028 & 0.0405 & 2431 & 455 & 10117 & 13003 \\
\hline 1984 & 60028 & 0.0421 & 2527 & 480 & 10117 & 13124 \\
\hline 1985 & 60028 & 0.0438 & 2629 & 1321 & 10117 & 14067 \\
\hline 1986 & 60028 & 0.0550 & 3301 & 530 & 10117 & 13948 \\
\hline 1987 & 60028 & 0.0571 & 3427 & 1034 & 10117 & 14578 \\
\hline 1988 & 60028 & 0.0594 & 3565 & 590 & 10117 & 14272 \\
\hline 1989 & 60028 & 0.0618 & 3709 & 625 & 10117 & 14451 \\
\hline 1990 & 60028 & 0.0643 & 3859 & 1848 & 10117 & 15824 \\
\hline
\end{tabular}

Present Worth (@ 8\%) $=\$ 92,260$

Levelized Cost (10 years @ 8\%) $=\$ 13,749$

(a) Seasonal system COPS for WSHPs vary depending upon the design of specific units and the blower and pumping allowances included. A seasonal system COP of 2.3 is used in this case. This includes both blower and pump allowances. The pump allowance is based upon $180 \mathrm{ft}$ total head and a $30 \%$ wire-to-water efficiency.

(b) See Figure 1.2.

(c) Based on $\$ 46 / \mathrm{hr}$ wage rate (1980 price leve1). Also includes $\$ 165 /$ year for sodium hypochlorite.

(d) See Table 6.11. 
TABLE D.15. Life Cycle Cost Calculation for Electrical Resistance Heating for Snettisham Salmon Hatchery

\begin{tabular}{|c|c|c|c|c|c|c|}
\hline & $\begin{array}{l}\text { Electricity } \\
\text { Required } \\
(\mathrm{kWh})^{(\mathrm{a})} \\
\end{array}$ & $\begin{array}{c}\text { Electricity } \\
\text { Cost } \\
(\$ / \mathrm{kWh})^{(\mathrm{b})}\end{array}$ & $\begin{array}{c}\text { Total } \\
\text { Electrical } \\
\text { Cost } \\
(\$) \\
\end{array}$ & $\begin{array}{l}\text { Annual } \\
\text { O\&M } \\
\text { Cost } \\
(\$)^{(c)} \\
\end{array}$ & $\begin{array}{c}\text { Annual } \\
\text { Investment } \\
\text { Cost } \\
(\$)^{(d)} \\
\end{array}$ & $\begin{array}{c}\text { Total } \\
\text { Annual } \\
\text { Cost } \\
(\$) \\
\end{array}$ \\
\hline 1981 & 205033 & 0.0160 & 3280 & -- & 5526 & 8806 \\
\hline 1982 & 205033 & 0.0160 & 3280 & -- & 5526 & 8806 \\
\hline 1983 & 205033 & 0.0160 & 3280 & - & 5526 & 8806 \\
\hline 1984 & 205033 & 0.0160 & 3280 & -- & 5526 & 8806 \\
\hline 1985 & 205033 & 0.0160 & 3280 & 272 & 5526 & 9078 \\
\hline 1986 & 205033 & 0.0254 & 5207 & -- & 5526 & 10733 \\
\hline 1987 & 205033 & 0.0254 & 5207 & -- & 5526 & 10733 \\
\hline 1988 & 205033 & 0.0254 & 5207 & -- & 5526 & 10733 \\
\hline 1989 & 205033 & 0.0254 & 5207 & -- & 5526 & 10733 \\
\hline 1990 & 205033 & 0.0254 & 5207 & 396 & 5526 & 11129 \\
\hline
\end{tabular}

Present Worth (@ 8\%) $=\$ 64,688$

Levelized Cost (10 years @ $8 \%$ ) $=\$ 9640$

\footnotetext{
(a) Electrical resistance heating assumed to be $100 \%$ efficient.

(b) Electricity cost through 1985 set at $\$ 0.016 / \mathrm{kWh}$. Electricity cost for 1986-1990 assumed to be $\$ 0.0004$ above wholesale rate.

(c) Based on $\$ 46 / \mathrm{hr}$ wage rate (1980 price levels).

(d) See Table 6.14.
} 
TABLE D.16. Life Cycle Cost Calculation for Water Source Heat Pump Heating for Snettisham Salmon Hatchery

\begin{tabular}{|c|c|c|c|c|c|c|}
\hline & $\begin{array}{c}\text { Electricity } \\
\text { Required } \\
(\mathrm{kWh})^{(\mathrm{a})} \\
\end{array}$ & $\begin{array}{c}\text { Electricity } \\
\text { Cost } \\
(\$ / \mathrm{kWh})^{(\mathrm{b})} \\
\end{array}$ & $\begin{array}{c}\text { Total } \\
\text { Electrical } \\
\text { Cost } \\
(\$) \\
\end{array}$ & $\begin{array}{l}\text { Annual } \\
0 \& M \\
\text { Cost } \\
(\$)^{(c)} \\
\end{array}$ & $\begin{array}{c}\text { Annual } \\
\text { Investment } \\
\text { Cost } \\
(\$)(d) \\
\end{array}$ & $\begin{array}{c}\text { Total } \\
\text { Annual } 1 \\
\text { Cost } \\
(\$) \\
\end{array}$ \\
\hline 1981 & 82013 & 0.0160 & 1312 & -- & 8645 & 9957 \\
\hline 1982 & 82013 & 0.0160 & 1312 & 324 & 8645 & 10281 \\
\hline 1983 & 82013 & 0.0160 & 1312 & -- & 8645 & 9957 \\
\hline 1984 & 82013 & 0.0160 & 1312 & -- & 8645 & 9957 \\
\hline 1985 & 82013 & 0.0160 & 1312 & 816 & 8645 & 10773 \\
\hline 1986 & 82013 & 0.0254 & 2083 & - & 8645 & 10728 \\
\hline 1987 & 82013 & 0.0254 & 2083 & 474 & 8645 & 11202 \\
\hline 1988 & 82013 & 0.0254 & 2083 & -- & 8645 & 10728 \\
\hline 1989 & 82013 & 0.0254 & 2083 & -- & 8645 & 10728 \\
\hline 1990 & 82013 & 0.0254 & 2083 & 1188 & 8645 & 11916 \\
\hline
\end{tabular}

Present Worth (@ 8\%) $=\$ 70,563$

Levelized Cost $(10$ years $08 \%)=\$ 10,516$

(a) Seasonal system COPs for WSHPs vary depending upon the design of specific units and the blower and pumping allowances included. A seasonal system COP of 2.5 is used in this case. This includes both blower and pump allowances. The pump allowance is based upon $140 \mathrm{ft}$. total head and a $30 \%$ wire to water efficiency.

(b) Electricity cost through 1985 set at $\$ 0.016 / \mathrm{kWh}$. Electricity cost for 1986-1990 assumed to be $\$ 0.0004$ above wholesale rate.

(c) Based on $\$ 46 / \mathrm{hr}$ wage rate (1980 price levels).

(d) See Table 6.14. 


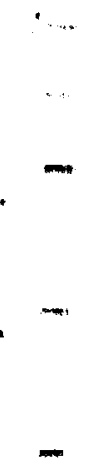

$n$

$\rightarrow$ 


\section{DISTRIBUTION}

No. of

Copies

OFFSITE

A. A. Churm

DOE Patent Division

9800 S. Cass Avenue

Argonne, IL 60439

10 Floyd R. Summers

U.S. Department of Energy

Alaska Power Administration

P.0. Box 50

Juneau, AK 99802

27 DOE Technical Information Center
No. of

Copies

ONSITE

DOE Richland Operations Office

H. E. Ransom

34 Pacific Northwest Laboratory

J. L. Eisenhauser (5)

C. I. Gibson (2)

J. J. Jacobsen (15)

J. C. King (5)

Technical Information (5)

Publishing Coordination KE(2) 


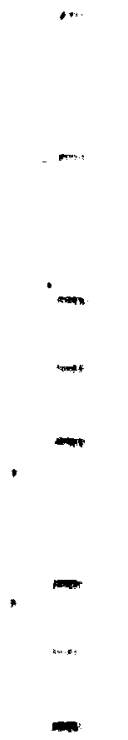

int

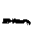

$-$

$m$

.

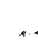

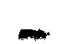

$n$

$-$ 